




\section{D. . . INSECTS}

\section{INSTINCT DISPLAYED.}

\section{FIFTH EDITION,}

CORRECTED AND ENLARGED BY THE AUTHOR OF

"SPAIN YeSTERDAT AND TO-DAY," "THE NEW ESTATE." \&C. \&C. 
LONDON :

PRINTED BY SAMUEL BENTLEY, Dorset Street, Fleet Street. 


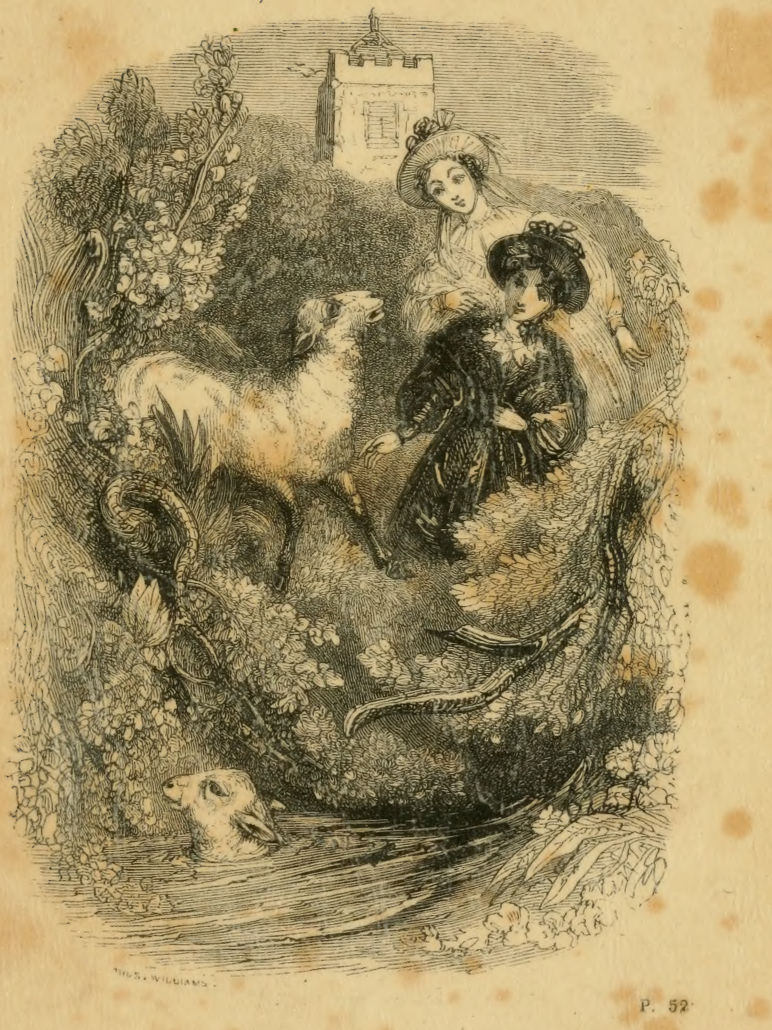

THE SHEEP AND HER LAMB. 


\section{Qh 751 W25 1836 Ent. \\ INSTINCT DISPLAYED,}

IN $A$

COLLECTION OF WELL-AUTHENTICATED FACTS,

EXEMPLIFYING THE EXTRAORDINARY SAGACITY

OF VARIOUS SPECIES OF

THE ANIMAL CREATION.

BY PRISCILLA WAKEFIELD.

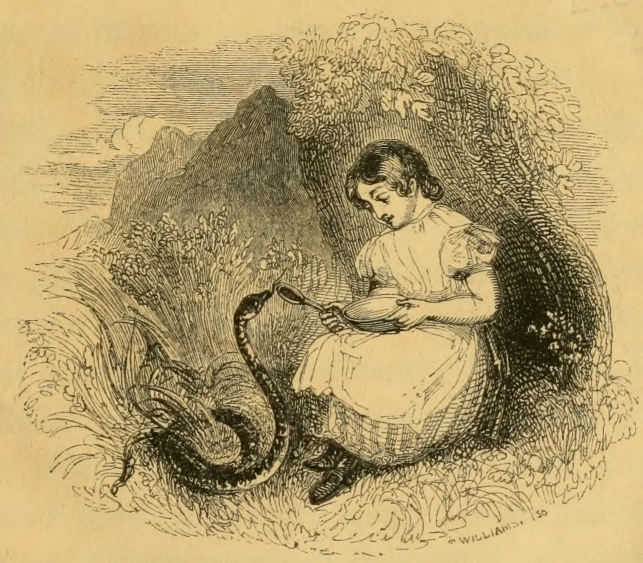

\section{LONDON :}

DARTON AND HARVEY, GRACECHURCH STREET. 1836. 



\section{P R E F A C E.}

THE distinctions between Reason and Instinct are difficult to ascertain: to define their exact limits has exercised the ingenuity of the most profound philosophers, hitherto, without success. Nor can the learned agree as to the nature of that wonderful quality, that guides every creature to take the best means of procuring its own enjoyment, and of preserving its species by the most admirable care of its progeny. Some degrade this hidden impulse to a mere mechanical operation; whilst others exalt it to a level with reason, that proud prerogative of man. There are, indeed, innumerable gradations of intelligence, as of the other qualities with which the animal kingdom is endowed; in like manner as the different orders of beings approach each other so closely, and are so curiously united by links, partaking of the nature of those above and those below, that 
it requires a discerning eye to know what rank to assign them. Thus, quadrupeds and birds are assimilated to each other by the bat; the inhabitants of the waters to those of the land by amphibious animals; animals to vegetables, by the leaf-insect, and by plants that appear to have sensation; and animate to inanimate, by the oyster, the molluscæ, and sea anemones.

Reason and Instinct have obvious differences; yet the most intelligent animals, in some of their actions, approach so near to reason, that it is really surprising how small the distinction is. The great and most striking superiority of reason seems to consist in these two points: the capacity of knowing and acknowledging our Creator, and of rendering its owner responsible for his conduct. Without investigating further the metaphysical distinctions of Reason and Instinct, to which I am quite incompetent, I will proceed to make some apology for the following work.

The harmonious beauty of creation, and the interesting objects it presents, have been my delight from childhood; and the enjoyments, as well as the advantages, I have received from this 
taste, have made me desirous of communicating it to others, by relating a few well-authenticated facts of the exact coincidence of the instinctive powers with the necessities of the animal. My friends, aware of my intention, increased the stock of my materials by several curious communications, which I thought more likely to arrest the attention of the young, when combined in the form of letters, than a long string of detached anecdotes, following each other like horses in a team.

My motive has been to excite attention to the propensities of animals, as a powerful antidote to treating them with cruelty or neglect, so often practised by the ignorant and thoughtless from inconsideration. Who can observe, without admiring them? Who can admire, without adoring that Power that has so eminently displayed his wisdom and goodness, in the endowments of every inhabitant of this globe, from man to the most minute insect that our microscopes discover ; - each created for a certain portion of enjoyment, adapted to its nature; with organs and dispositions so exactly fitted to procure this peculiar 
enjoyment, that none can doubt its being the work of an all powerful, infinitely wise, and benevolent Being.

Conscious of inability to do justice to so noble a subject, I trust that my good intention will be received with the same indulgence as has been so often manifested on former occasions; and if by this small collection of instances of animal sagacity, I have added a book of entertainment to the common stock, that neither corrupts the mind, nor vitiates the taste of the rising generation, my endeavours will be well rewarded. 


\title{
CONTENTS.
}

\author{
LETTER I. \\ FROM CAROLINE TO EMILY.
}

Employment in London.-Early Friendship. . . $\quad \begin{array}{r}\text { Page } \\ 1\end{array}$

LETTER II.

FROM THE SAME TO THE SAME.

Journey into the Country. - Reception by her Aunt and Cousin. - The Country. - Change of Pursuits. - The Poultryyard._Daily Reading of the Scriptures. - The Garden.-Employment of Time. . . . . . . . 4

\section{LETTER III.}

FROM THE SAME TO THE SAME.

Advantage of Employment.-The Children's School.-Study of Natural History. . . . . . . . 11

\section{LETTER IV.}

FROM THE SAME TO THE SAME.

Character of Mr. Palmer.-Animal Instinct.-Definition of Instinct.-Uniformity of Instinct.-Reason peculiar to Man.Reason Progressive.-Operations of Reason and Instinct.-Instinct in choice of food.--Instinct of Insects.-Instinct adapt 
itself to change of circumstances.-Ingenuity of a Dormouse.Anecdote of an Ass._Punishment of Criminals. - Page 14

\author{
LETTER V. \\ FROM THE SAME TO THE SAME.
}

Ants.-Termites, or White Ants.-Termites.-Their Habits. - Habits and Uses of Termites. - Termes Bellicosus-its Nest. -Changes of Termes.-Commencement of Nest.-A partments of the Nest.-Roof of Nest water-proof. - Internal arrangement.-King and Queen.-Ants avoid the open air._Opening an Ant-hill. - Termites on a march. - Varieties in mode of building. • • • • • • • • • 29

\title{
LETTER VI. \\ FROM EMILY TO CAROLINE.
}

Caroline's studies commended. - Anecdote of two Magpies. -Food and Habits of Magpies. . . . . . . 48

\section{LETTER VII. \\ FROM CAROLINE TO EMILY.}

An Evening's Walk.-The Sheep and her Lamb.-Affection of Sheep.-Courage of Sheep.-Sheep attached to localities. Gordius Marinus.-Its Agility.-Reflections.-History of Rachel's Linnets.-Cruelty of confining Birds. . . 51

\section{LETTER VIII. FROM EMILY TO CAROLINE.}

Anecdote of a Sparrow.-Sagacity of a Sparrow.-Question to Naturalists.-Defensive Precautions of various Animals.-Echinus, or Sea-hedgehog.-A nimals in Falkland Islands.-Patience compels praise. 
LETTER IX.

FROM CAROLINE TO EMILY.

A necdote of two Goats.-Ingenuity of Goats.-Harmony of Instincts and Habits.-Tractability of Goats.-Their Flesh.A Wedding.-Visits to Poor Neighbours.-Virtue excites Emulation.

\section{LETTER X. \\ FROM THE SAME TO THE SAME.}

Bats.-Structure of the Bat.-Its Habits.-Sensibility of the Bat's Wing.-Torpidity of the Bat.-Analogous cases of vitality suspended in Winter.-Wisdom of the Creator. . . 77

\section{LETTER XI.}

Shepherd's Dog.-Feat of a Sheep-dog.-Anecdote of Mr. Hogg's Dog.-Great utility of Sheep-dogs.-Saga'city of Dogs. -Canine Fidelity. - Discrimination of Dogs. - Anecdote of a Terrier.-Friendly apology. . . . . .

\section{LETTER XII. \\ FROM EMILY TO CAROLINE.}

Ingenuity of two Goats. - Fidelity of a Spaniel. - His death from grief. - A Man saved by a Dog's sagacity. - Newfoundland Dog.-Uses of Natural History. . . . 9

\section{LETTER XIII.}

\section{FROM CAROLINE TO EMILY.}

Eulogium on Letters. - Submission to the Divine Will.Pleasures of an active Life.-Exploits of a Roman Dog.-Character of the Cat.-Anecdote of a Cat.-Cats attached to houses. - Encrinites.-Works of Nature unheeded.-God's Works full of Wisdom. 
LETTER XIV.

FROM EMILY TO CAROLINE.

Country and Town contrasted.-Frivolity and Inhumanity.Learned Women and Sciolists.--Story of a Monkey.-Malice of the Monkey.-A natural illumination.-Combat of a Tiger and Buffalo. • . . . . . . Page 112

\section{LETTER XV. \\ FROM CAROLINE TO EMILY.}

Irascibility of the Camel.-Management of the Dromedary. -Peculiarities of the Camel. - Properties of the Rein-deer.Structure of the Viper.-Fascination of Serpents.-A Mouse and Viper.-Anecdotes of Mr. Palmer.-A Christian Pastor.A happy Family. . . . . . . . 120

LETTER XVI.

FROM EMILY TO CAROLINE.

Velocity of particular Animals.-Comparative swiftness of Quadrupeds and Birds.—Carrier Pigeons and Rooks. . 130

\section{LETTER XVII.}

FROM CAROLINE TO EMILY.

Birds of Passage. - Birds which visit Britain. - Migratory Water-fowl.-Britain deserted by some Birds.-Peculiarities in Animal Migration.-Migration of Fish.-Migration of Rats.Great Norway Rats.-Visit to Sea-coast Proposed. . 136

\section{LETTER XVIII. \\ FROM THE SAME TO THE SAME.}

A united Family.-Form and Habits of the Puffin. - Puffins inimical to Rabits.-Land-crabs of the Bahamas.-Their Jour- 
ney to cast their Spawn.-Fenovation of Shell in Land-crabs.Sagacity of a House-dog.-Evil of bad Companions.-Welltime Lenity. . . . . . . . Page 145

LETTER XIX.

FROM EMILY TO CAROLINE.

Anecdotes of Animals.-A blind Man's Dog.-Ingenuity of a Horse.-Docility of the Goldfinch.-A Pig and Badger used as Pointers. - Story of a Child and Snake. - Attachment to Home. • . . . . • . . . 154

\section{LETTER XX. \\ FROM CAROLINE TO EMILY.}

A delicate Benefaction.-A Nest incased in growing Wood.Story of a pair of Eagles.-An Eaglein confinement.-Deviations from pure Instinct.-Instinct modified by circumstances.

161

\section{LETTER XXI. \\ FROM EMILY TO CAROLINE.}

Friendship of a Horse and Dog.-A domesticated Peewit.Animal antipathies overcome. - Animals reared by the Cat.A Badger suckled by a Cat.-Eels and Salmon of the River Ban. -Singular Stratagem of Eels.-God's care of his Creatures. 168

\section{LETTER XXII. \\ FROM CAROLINE TO EMILY.}

Animal and Vegetable coincidences. - Power of Rhinoceros to inflate his Skin. - Organic Structure of Fish. - Teredo, or Ship-worm.-Herbivorous and Carnivorous Animals,-General Diffusion of Animal Life. - Pleasures derived from the Senses. -Man's peculiar Pleasures Intellectual. - God's goodness ineffable. 


\section{LETTER XXIII. FROM EMILY TO CAROLINE.}

Superior Instinct of certain Animals. - A Child fed by a Dog. -A Whale chased by a Dog. - Docility and attachment of a Dog.-The Dog of Montargis. - Combat between the Dog and Murderer.-Conscience disarms the Murderer. - Page 185

\section{LETTER XXIV.}

\section{FROM CAROLINE TO EMILY.}

Story of a Shepherd's Dog.-A Dog trained to go on Errands. -Ingratiating Amiability of a Dog.-Canine Patience.-Dog's distress at loss of its Young.-Singular Actions of a Cat.-Kittens adopted by a Dog.-Sagacity of a little Terrier. 193

\section{LETTER XXV. \\ FROM EMILY TO CAROLINE.}

Vast distances travelled by Cats. - Domesticated Wild-fowl. -A Horse trained to feign Death.-Story of Indian War Elephants. - Docility of Elephants. - Their useful Properties. Elephant in a state of anger. • • . . . 202

\section{LETTER XXVI.}

\section{FROM CAROLINE TO EMILY.}

Amiable qualities of Animals.-A ferocious Bull reconciled to the object of its hostility.-Treatment of Animals.-Affection of a Linnet.-Attachment and Antipathies of a Linnet.-Affection of a Peacock to his Mate.-The Dog of Ulysses. - 211

\section{LETTER XXVII.}

\section{FROM EMILY TO CAROLINE.}

Anecdote of Monkeys.-Cubbeer-burr.-Hindoo superstition. -Imitative faculty of Monkeys.-Ape, an ugly copy of Man. 
- Ribbed-nose Baboon. - Orange Monkey. - Apes, Baboons, and Monkeys.-The Oran Otan.-Anatomy of the Oran Otan. - Habits of the Pigmy Ape. - Malice of the Barbary Ape.Hare-lipped Monkey. - Chinese Monkey. - Monkey called the Preacher.-Activity of the Squirrel Monkey. - Female Monkey and her Young.-Tails of Sapajous and Sagoins. Page 221

\section{LETTER XXVIII.}

\section{FROM CAROLINE TO EMILY.}

A Dog employed in Salmon Fishing. - Phosphorescence of the Ocean.-Gratitude of an Elephant. • • • 238

\section{LETTER XXIX.}

\section{FROM EMILY TO CAROLINE.}

Olfactory Sense in Animals.-Acuteness of Canine Scent.Reflections on Animal endowments. - Domesticated Tigers. Tiger and Elephant compared. - Sympathy between Elephants. -Decoy Elephants.—Rage of entrapped Elephant. . 242

\section{LETTER XXX.}

FROM CAROLINE TO EMILY.

Character of Mrs. Saville.-Anecdote of the Irish Rebellion. -Fidelity of a Dog. - Remarkable fast of a Dog.-Dog's attachment to his Master. - Long journey of a Dog. - Metrical Summary of Canine Services.-Rachel's Newfoundland Dog.

\section{LETTER XXXI.}

\section{FROM EMILY TO CAROLINE.}

Wedded happiness. - Minnows. - Bird's Nest in Block of a Mast.-A Chaffinch and his Mate. - Nest in Cavity of a Mast. -Superstition of Seamen.-Fishing by Pelican and Cormorant. 
-Pelican's Nest.-Pelicans on the Niger.-Ingenuity of Crows. - Happiness of a future state. . . . . Page 258

\section{LETTER XXXII.}

\section{FROM CAROLINE TO EMILY.}

Advantages of studying Nature.-A nimals adapted to their Station. - Story of a Spaniel. - Peculiarities of Insects. Various haunts of Insects. - Devastations of Insects. - Spider's Web.-Jamaica Spider.-Ichneumon Flies.-Instinct of Wasps. -Nymphæ of Water-moths. - Instances of mistaken Instinct.

\section{LETTER XXXIII. \\ FROM EMILY TO CAROLINE.}

Wanton cruelty condemned. - Humanity should be early inculcated.-Sullivan the Whisperer.-Singular mode of breaking Horses.-Habits of the Horse. - Its character.-An American Sow.-Good wishes of Emily. . . _ . . 281

\section{LETTER XXXIV.}

\section{FROM CAROLINE TO EMILY.}

Caroline regains her Fortune.-An invitation to Emily.-Instinct weakened by domestication.-Kine in a wild state.-Beaver in the wild state. - Beaver in captivity. - Restlessness of captive Beaver.-Man in a savage state. - Endowments of the savage.-Highland Cattle. - Influence of Music on Cattle.Sagacity of a Bull. - Trespassing Cows checked by a Bull. Conclusion. 


\section{INSTINCT DISPLAYED.}

\section{LETTER I.}

FROM CAROLINE TO EMILY.

\section{DEAR EMILY,}

To-Morrow will be my birth-day, when I shall be eighteen. A large party was invited to celebrate the day, and great preparations were made for the occasion: the drawing-room in my guardian's house was to be decorated with festoons of natural flowers, illuminated with coloured lamps; music was ordered, that my juvenile visitors might be entertained with a dance; and I thought of nothing but pleasure. Little aware of the uncertainty of the future, I was ill qualified to bear the disappointments that have followed these prospects of joy.

Mr. Campbell, whom I have regarded as a father ever since I can remember, and in whose hands my whole fortune was placed, has made some unfortunate 
bargains on the Stock Exchange, by which he is ruined; and I am obliged to depend for subsistence on the bounty of my mother's sister, who lives with her daughter, on a small income, in a retired part of Wales.

Educated as I have been, in a fashionable manner, and accustomed to the gaieties of London, how shall I bear the uniform secluded life that my good aunt and cousin lead in the country? Since I left school, my time has been at my own disposal: the mornings have generally been devoted to shopping with young ladies of my acquaintance, a promenade in the park, or some other similar amusement: my afternoons have always passed in company at home, or parties abroad. The few intervals of leisure that I could command from these daily engagements were spent at the piano-forte, or in reading books of entertainment. What an insufferable change must I endure, to be confined to the society of two persons, both strangers to those pursuits that I have been accustomed to consider as the prime enjoyments of life: to be banished from London, and obliged to pass my existence in a country village, where the sound of a coach is seldom heard! To-morron, instead of my birth-day festival, I depart from the gay metropolis in a stage-coach; and, if I reach the place of my destination in safety, I will give you an account of 
my reception, and tell you with what composure I bear the new mode of life I am compelled to embrace.

Whatever misfortunes befal me, I flatter myself, my Emily, I shall still retain the same place in your affections that I have enjoyed ever since we were placed together at the same school; and though capricious Fortune frowns on me, whilst she continues to smile graciously on you, that your friendship will be undiminished towards your unhappy

Caroline. 


\section{LETTER II.}

FROM THE SAME TO THE SAME.

MY DEAR EMILY,

The uneasy motion of the coach, and my depression of spirits, rendered my first day's journey inexpressibly fatiguing: at night, weary as I was, I had no maid to assist me in undressing. I then felt, for the first time, that a fine lady is a very helpless being; and I comforted myself with the reflection, that necessity would at least teach me to wait upon myself. Notwithstanding the novelty of my situation, in an inn, and amongst strangers, I slept soundly, and arose more capable of attending to the civilities of my fellow-travellers than the day before. For, believe me, Emily, the kindness of these people, whom, a few days before, I should have regarded with false pride as my inferiors, was a great consolation to me in my forlorn situation. In the evening I arrived at my aunt's, rejoiced to find myself under the protection of one who owned me for a relation. My cousin met me at the door with a most engaging welcome. She is about two years older than I am. Her face is not regularly handsome, but 
an inexpressible sweetness is spread over every feature: her mouth, especially, has the most gracious smile you can imagine. The first glance assured me that I should not be miserable with such a companion. She introduced me to my aunt, who was sitting in a parlour neatly furnished with white dimity, that overlooked a delightful view of an extensive country. She rose to receive me, and, with the tender salute of a mother, bid me consider her house as my future home. The thoughts of dependence brought tears from my eyes: I could only stammer out my thanks in broken accents. She seemed to perceive the cause of my tears; but, without making any remark, changed the conversation to the occurrences of my journey, and united with her daughter in every kind attention that could have been paid to the most respected visitor, rather than a poor dependent relation who sought an asylum from their bounty. My aunt is about fifty, and has been extremely handsome: benignity and intelligence are marked in her countenance, and a certain dignity of manner that impresses respect mingled with love. Two such persons I did not expect to find in a Welsh cottage; for the house deserves no better title, though it has every convenience the wants of the family require. I have a chamber to myself, and view from my window a prospect that might supply Salvator Rosa 
with a subject: a mountain of sublime height rises before it, partially clothed with trees of varied beauty; through the midst of them rushes a cascade, which, after rain, swells to a cataract, dashing its silvery foam against the craggy rocks. The house is white on the outside, and stands in the midst of a garden, which my aunt and cousin cultivate with their own hands. The country around is beautiful and romantic: the walks are really charming, and, to me, full of novelty. The first few days I seemed stupid, and passed my time without employment. Miy aunt, who made allowance for my former habits, as well as my awkwardness in those occupations that fill every hour of their time, asked me, one morning, if I should not like to have something to do; and added, that the best cure for melancholy was a succession of agreeable business. She then requested me to gather some flowers, and new dress the bouquets that adorn the chimney-piece. After many trials before I could arrange them to my own satisfaction, I finished them, as my aunt and cousin kindly told me, with some taste. Finding me pleased with my task, she has since given me others, which, though very different from town amusements, are not without interest. You would smile to see me equipped in a printed apron, and a basket of corn on my arm, as soon as breakfast is over, to accompany Rachel to the 
poultry-yard, where we are presently surrounded by a numerous tribe of the feathered race, who divert me extremely with their rivalships, their quarrels, and, above all, with the tender care of the hens for their young broods. The moment we enter, all is bustle and noise: each eager to push through the crowd, in order to pick up the first grain that falls from my basket. The king of our yard is remarkably beautiful: I cannot describe him better than in the words of Dryden :

" High was his comb, and coral red withal, In dents embattled like a castle wall;

His bill was raven black, and shone like jet; Blue were his legs, and orient were his feet;

White were his nails, like silver to behold: His body glitt'ring like the burnish'd gold."

This handsome bird struts about with an air of majesty, attended by the females, who are also very pretty; for Rachel is attentive to bring up those which are the beauties of the brood. To give you the history of one of our days, I should begin with the morning. I rise at six, three or four hours before my accustomed time: this gives me a day before you are awake, and my health is already improved by it. You would be surprised to see how rosy I am grown. As soon as we are dressed, we all assemble in the common parlour, to hear Mrs. Saville read a chapter in the 
Bible, which she has begun on my account, as I had only read scattered passages at school. Could you be present at our morning orisons, you would be charmed with the impressive manner in which my dear aunt reads the sacred volume. I never heard any thing so solemn before. Sarah, an old servant, who has lived many years in the family, and has faithfully adhered to her mistress through all the vicissitudes she has undergone, always attends; besides a young girl, named Fanny, that my aunt has taken from a neighbouring cot, to assist Sarah in the laborious part of the work. At first, I was astonished to see the servants take their seats amongst us ; but my aunt, without appearing to condemn my foolish pride, convinced me that the salvation of the meanest of mankind is as important in the sight of the Universal Father as that of the most powerful monarch, and that heads of families are bound to use their utmost endeavours to afford religious instruction to every branch of their household.

When reading is finished, we walk in the garden whilst breakfast is made ready. This sweet enclosure reminds me of the hanging gardens of Babylon; for it is partly formed on the side of a hill, and the walks wind up the ascent, forming terraces one above another; the uppermost shaded with a row of tall trees. On one side is a grove, with underwood of 
nut-trees; and at the bottom glides a clear stream, in which we often watch the gambols of the fishes, for our amusement. Choice flowers, of various kinds, are cultivated with great care; for both my companions are skilful florists, as well as botanists. One part, concealed by a shrubbery, contains all kinds of useful vegetables, and simples for medicines, which Mrs. Saville dispenses to the poor; for she is their doctress, their counsellor, and their friend. Did you know how she is reverenced and belored, you would not think me quite so much to be pitied. An hour or two is devoted to gardening, by Rachel and myself; (for I am learning to be useful;) whilst my aunt overlooks her family concerns, and attends to the applications of the poor. I have not yet discovered the secret of her management; for, with a very limited income, she has always the means of relief for the truly distressed. But more of this hereafter.

When our business is finished, we sit down to useful needlework, whilst one of us reads some instructive book to the rest. The most handsome piece of furniture in Mrs. Saville's house, is a large mahogany book-case, well supplied with a select collection of books in most sciences. This she calls her treasure, and says it is the only fragment she has saved from the wreck of her early fortunes. In her husband's 
life-time she was accustomed to all the indulgences of affluence; but Mr. Saville having lived to the utmost verge of his income, and his estate being entailed, it went to a male heir, and, consequently, very little remained for her.

We dine early, and the afternoons are often passed in drawing; an art in which Rachel excels, particularly in taking views from nature. Sometimes we converse or walk; and, they tell me, they occasionally pass an hour or two at the parsonage-house. But I have not yet seen either Mr. Palmer or his wife, as they are gone on a short excursion to the sea. We close the day, as we began it, with the Bible; and retire to rest before the London fashionables have finished their dinner.

However Gothic this mode of living may appear to you, I begin to think it is rather more reasonable than that into which I was cast at Mr. Campbell's. Time is requisite to reconcile the mind to new views; and regret will sometimes force itself on my mind at the recollection that I was so lately the gay, modish, and admired Caroline Greville; and that now I am an obscure, dependent, country girl. The thought would overwhelm me, did not the example of Mrs. Saville convince me that it is possible to endure such a metamorphosis and be happy. Adieu. You shall soon hear again from

Caroline. 


\section{LETTER III.}

FROM THE SAME TO THE SAME.

So, my dear girl, all my acquaintance pity me, and wonder how I exist. You may tell them that I begin to like my new manner of living, and believe, when I am more accustomed to it, I shall become quite fond of it. My time never passed so quickly; for I am always employed. If I happened to be alone when I lived in London, how tedious the hours seemed! because, without an engagement, I had no pursuit. Now the case is widely different: every occupation is interesting. Do not suppose that there is no variety: Mrs. Saville's conversation alone is a fund of amusement and instruction. She has seen a great deal of the world, mixed much in society, has studied mankind, and enriched her mind with reading. She possesses the uncommon art of correcting the faults of those she is with, so agreeably, that she wins their love whilst she obliquely reproves them.

By leading me to a succession of employments, she has almost cured me of that slothful habit of lounging away time in doing nothing, or some trifle equivalent to it.- "Chase away your chagrin, Caroline," says she, 
seeing me look thoughtful, " by pursuits that enlarge your understanding and improve your heart. Come with me, my love; you shall assist me in teaching twenty little girls their duty, in a school that $I$ have established at a short distance. Their good dame, to whom I pay a small stipend, instructs them in reading and working; but I take upon myself to explain the importance of religion and virtue, the necessity of governing the temper, and the advantages of order and good habits. The little prattlers all love me; and I seldom pass an hour more pleasantly than in beholding the improvement of this innocent assembly." I accompanied her to the school, and enjoyed a delight that I had never felt before. I intend to repeat my visits, and have taken particular charge of six of these children. At the sight of their benefactress, love and reneration were spread on every countenance, and each seemed eager to obtain a smile of approbation.

Sometimes our table is covered with maps of different countries; and my aunt elucidates the climate, produce, and character of the inhabitants of each.

Her favourite study is Natural History, in which she is assisted by Mr. Palmer, who has a very extensive knowledge on the subject. They wish to initiate me, but I am such a novice that I fear they will have a great deal of trouble. However, I am desirous of turning my attention that way, from the pleasure I 
perceive every object affords to my aunt and cousin ; for Rachel, too, is a naturalist. The most insignificant flower or insect is to them a subject of admiration. They glean from this source many enjoyments to which I am a stranger.

Mr. Palmer has engaged us to attend a lecture at his house twice a week; the substance of which I am to write down, and shall send to you, if you have time or patience to read them.

Thus does this enlightened woman contrive to provide a succession of amusements in this retired solitude; and so happily do I spend my time, that, except being an incumbrance to Mrs. Saville, I would not resume my former situation for any consideration. And then, my sweet Rachel, (but you must not be jealous,) she is so affectionate, so amiable, so modest, and such a pattern of filial piety, that I love her entirely, and am fully conscious of my own inferiority. The separation from you is one of my greatest troubles; but I rejoice that this mode of communication still enables me to assure you, that I am, with unalterable regard,

\section{Your}

Caroline. 


\section{LETTER IV.}

FROM THE SAME TO THE SAME.

\section{DEAR EMILY,}

Mr. and Mrs. Palmer are a pleasing couple: superior to the flippancy of modish politeness, they are sufficiently refined for the society of any rank, whilst they possess an ease and simplicity which are quite charming. He is the father of his parish. His business is to instruct the ignorant, relieve the distressed, visit the sick, comfort the afflicted, and reform the vicious. When these important and interesting duties give him leisure, the study of nature is his recreation. His wife is young and pretty: she is a model of domestic management, and is the governess as well as the mother of the children. We spent a long afternoon with them yesterday: the conversation turned upon instinct, and since you express an inclination to profit by my studies, I shall give you Mr. Palmer's opinion on the subject, in the clearest manner I am capable of expressing it.

"Thesubject of animal instinct," said he, "comprises many other interesting subjects, and requires an accurate investigation of the habits of animals. Dr. Paley, 
in conversation, once defined instinct ' as a propensity prior to experience ;'-a definition that aptly expresses those unerring operations of the animal, and more especially the insect tribe, by which their food is obtained, and the safety and provision of their future offspring secured, when they themselves have ceased to exist, and which we again perceive to be punctually and circumstantially followed by their young, unaided by parental precept or example. It has been justly remarked that * " the sagacity and laborious industry exerted in the various instances of animal architecture have one uniform tendency. They are all designed for the multiplication, protection, and nourishment of offspring. But many of them are so artful, and require such persevering labour, that the human mind is bewildered when it attempts to reason upon them. Some philosophers have had recourse to conformation of body, and mechanical impulse, to account for it. Their reasonings, however, though often ingenious, involve the subject in tenfold obscurity. We can hardly suppose that the animals actually foresee what is going to happen, because, at first, they have not had even the aid of experience; and, particularly in some of the insect tribes, the parents are dead before the young are produced. Pure instincts of this kind, therefore, must be referred to an-

* Smellie's Philosophy of Natural History, vol. xi. page 118. 
other source. In a chain of reasoning concerning the operations of nature, we are under the necessity of resorting to an ultimate cause, which, though unable to trace through all its ramifications, and only to understand partially some of its effects; yet from those effects, thus dimly seen, we perceive the most consummate wisdom, the most elegant and perfect contrivances, to accomplish the multifarious and wonderful intentions of nature. In contemplating the operations of animals, from man down to the seemingly most contemptible insect, we are necessarily compelled to refer them to pure instinct, or original qualities of mind, variegated by nature according as the necessities, preservation, and continuation of the different species require.'*-'Reason acts with intelligence and design, profiting by experience, comparing motives, balancing probabilities, and is able to adapt itself to every change of circumstance. Hence, if there be any actions which are performed with every indication of design, forethought, and wisdom, which are not the result of instruction nor of individual experience, but of a power operating above the consciousness of the creature, and directing it with unerring certainty to the desired end by means far above its comprehension whether in man or brute, those actions are instinctive: if, on the other hand, there be any actions which

* Hancock, p. 16. 
evidently result from observation and instruction, indicating an intelligent power of combining means, and adapting them to ends of which the creature is conscious, these actions come within the province of reason. Addison, in speaking of instinct, remarks, ' I look upon instinct as upon the principle of gravitation in bodies, which is not to be explained by any known qualities inherent in the bodies themselves, nor from any laws of mechanism; but, according to the best notions of the greatest philosophers, is an immediate impression from the first Mover, and the Divine energy acting in the creatures :

For reason raise o'er instinct as you can, In this 'tis God directs, in that 'tis man.'

"The exact limits of instinct are difficult to define, as the sagacity of animals often approaches to reason, and appears to outstep that faculty, which forms part of their nature, and impels them to certain actions that are essential to their well-being, or that of their offspring. In animals of the same species, instinct is invariably the same; though the individuals that compose it have never had an opportunity of learning it from example. A canary-bird hatched in a cage, builds a nest as similar to those formed by canary-birds in their native woods, as she can with the materials that are given her; yet she has seen none of those of her own species for a model. 
"Instinct directs each kind of bird to choose that material, and to adopt that peculiar form, that best suit the constitution and number of her young. This impelling principle guides the eagle to fix her eyry on the summit of a tall tree; whilst the lark, moved by the same irresistible inclination, places her humble dwelling on the ground. Were the feathered tribes led by accidental choice alone, great confusion would ensue. A waterfowl might build in the sandy desert, whilst an ostrich might destroy her future progeny by laying her eggs on the bank of a river; whereas, under this infallible director, every oviparous animal deposits its offspring in that situation where it is likely to find protection against injuries, and a plentiful supply of food.

"The results of instinct are stable, and exactly adapted to the wants of its owner as a species, whether beast, bird, fish, or insect: but reason is a yielding quality, governed by circumstances, and accommodating itself to the particular inclination or desires of the individual. Instinct teaches men to shelter themselves from the inclemencies of heat and cold; but reason enables every man to choose a dwelling and situation peculiarly adapted to his own taste and convenience. Reason, consequently, is various : instinct uniform. The first is the privilege of man, and is the test of an intellectual nature: the latter 
has something belonging to it almost mechanical, and marks no degree of superiority or merit in the possessor. One bee is as expert in forming the cell with geometrical exactness as another. The individuals of a whole species are equally skilful in performing the tasks of instinct: each fulfils his part in perfection, nor do they ever improve or degenerate: the bees of the present day do not excel those in the days of Adam. The same remarks belong to all the various tribes of animals : they rear their young, procure their food, and defend themselves from their enemies, as well as the first of their kind, and no better.

"Here, then," continued he, " is a clear distinction between reason and instinct.

"Let us pursue the comparison.-Reason is progressive; not only from infancy to mature age, but from one generation to another, as appears by the progress from the savage state to that of a highly civilized nation. In the first periods of society, men only supply the absolute wants of nature: but, as they advance, knowledge, founded on experience, produces the rude beginnings of the sciences; useful discoveries are made, inventions are multiplied, and the comforts of human life augmented. But the arts of animals, if the expression is allowable, are always stationary, and reach at once to perfection. Every individual knows its proper business, without a model 
or a teacher. Another remarkable difference subsists between reason and instinct: the former is directed by motives, whilst the latter seems to have no other design than the gratification of an irresistible impulse. Men weigh consequences, and act according to their view of the readiest means of producing certain effects : animals perform their instinctive habits without foreseeing the result.

"As an example of this distinction, let us trace the operations of a man going to erect a mill. First he calculates the extent of his means, and whether his finances are adequate to the undertaking. $\mathrm{He}$ chooses a proper situation; purchases timber; engages numbers of his fellow-men, skilled in different arts, to assist him-bricklayers, carpenters, and blacksmiths. For each he provides proper tools and materials; and when they are set to work, every part is contrived to answer a particular purpose, and is adapted to a determined place. He also takes into consideration the use for which it is designed; whether it is to grind corn, or any other article that may require different machinery: and lastly, whether it is to be set in motion by wind, water, or steam. All this demands reflection, contrivance, design, science, and experience ; of which the most sagacious animal that was ever discovered is wholly incapable. A bird lays the twigs for her nest, and lines it in the same manner as her 
ancestors did before her, without these mental operations. Many animals store their provisions, that can have no foreknowledge of the change of seasons. Men sow, reap, and gather in the fruits of the earth, from experience and reason, which teach them the necessity of providing, in the abundance of the one, for the sterility of the other. Men act from motives; animals from their propensities. Reason is more dignified than instinct; but the latter excels reason in the perfection of its operations. The cells of a bee-hive are constructed upon geometrical principles; yet all the cells of every hive, even in different countries and ages, have always been, and still are, of the same shape and proportions. Show me the artist that could form twenty thousand of these minute cells with such exactness, let his tools be ever so nicely adapted to the purpose.

"The complete operations of instinct are greatly promoted by the admirable conformity of the organs of each animal to its modes of life; which combines with the exquisite perfection of their senses, to enable them to perform their respective tasks, in a manner superior to the most ingenious imitations of men. But some creatures, it must be confessed, display an extraordinary sagacity, particularly when domesticated, adapted to circumstances, and seeming to approach to reason. This is consistent with the order of nature, which is 
composed of gradations, which are so closely linked together, that it is very difficult to define the limits of the different classes.

"Another illustration of the wonderful manner in which pure instinct operates, is the choice which different animals make of plants for food. Smellie* remarks, that there is hardly a plant that is not rejected as food by some animals, and ardently desired by others. The horse yields the common water-hemlock to the goat, and the cow the long-leafed water-hemlock to the sheep. The goat again leaves the aconite or wolf's bane to the horse. The euphorbia, or spurge, so noxious to man, is greedily devoured by some of the insect tribes. The leaves of the broad-leafed kalmia are feasted upon by the deer and the round-horned elk, but are mortalìy poisonous to sheep, to horned cattle, to horses, and to man. The bee extracts honey from this flower, without injury to itself; but the man who partakes of this honey after it is deposited in the hive-cells falls a victim to his repast. 'In the autumn and winter of the year 1790, at Philadelphia, extensive mortality was occasioned among those who had eaten of the honey collected in the neighbourhood of that city, or had feasted on the common American pheasant, or pinnated grouse, as we call it. The attention of the American government was ex-

* Vol. i. page 350 . 
cited by the general distress, a minute examination into the cause of the mortality ensued; and it was satisfactorily shown that the honey had been chiefly extracted from the flowers of the kalmia latifolia, and that the pheasants which had proved thus poisonous, had fed harmlessly on its leaves. The consequence was that a public proclamation was issued, prohibiting the use of pheasants as food for that season.*

"Kirby t observes that the instincts of a considerable number of insects are endowed with an exquisiteness to which the higher animals can lay no claim. What bird or fish, for example, catches its prey by means of nets as artfully woven and as admirably adapted to their purpose as any that ever fisherman or fowler fabricated? Yet such nets are constructed by the race of spiders. What beast of prey thinks of digging a pit-fall in the track of the animals which serve it for food, and at the bottom of which it conceals itself, patiently waiting until some unhappy victim is precipitated down the sides of its cavern? Yet this is done by the ant-lion and another insect : and even the dwellings of the beaver, and the hanging nest of the tailor-bird, exhibit less wonderful and elaborate indications of instinct than a society of bees, with all their

* Oration, by Dr. Mason Good, p. 24.

+ Vol. ii. p. 472. 
peculiar arrangements for the future, and the good order of a numerous society of different gradations of rank and utility. It is, however, in the deviations of the instinct of insects, and their power of adapting their operations to a change of circumstance that the exquisiteness of these faculties is most decidedly manifested. If the nest of a bird is pulled out of a bush, though otherwise uninjured, she has no resource but to build another; but if insects in particular situaations are disturbed in their usual mode of proceeding, $o r$ by the act of man placed in entirely novel circumstances, they surprise us by the wonderful ingenuity with which they adapt their actual powers to their new position. I once confined the caterpillar of the puss moth in a small basket, when about to undergo its transformation into the chrysalis state. It was covered over with a fine piece of net at the top. Two were in the same basket: one fixed itself to the lace net, the cotton texture of which was evidently preferred by it to the smooth osier, for it rambled all round its enclosure and seemed to be choosing with great deliberation a favourable spot to begin its operations. When decided, it thickened the lace by smearing it with a strong glutinous liquor from its mouth, which, though it fastened backwards and forwards in thick filaments, it afterwards so covered with this viscous liquid as to leave no traces of thread. But this 
did not seem sufficiently secure, for it gnawed off portions of the basket, an operation which was most distinctly heard, and then worked up these minute fragments with the gum from its mouth: in this manner it formed a solid case, which dried as hard as stone; and as the basket was in part green and white, these colours were speckled minutely over its case. The other caterpillar confined with it, chose the bottom of the basket; but the surface was evidently unsuitable to it. It repeatedly begun and discontinued its spinning till a leaf was thrown in; on this it immediately seized, and rolling it or rather disposing of it in a hollow form, it immediately attached it to the bottom and side of the basket by liquor from its mouth, and then proceeded in all respects like the other caterpillar, gnawing off portions of the basket, and scattering them over the case till it was rendered quite firm and hard. The astonishing power of the creature was shown in the manner it bit off these minute portions, the sound of which was remarkably clear and distinct. It is probable that if left to itself it would have used sand or earth; but I never saw a cocoon made by this caterpillar when at liberty to choose its own materials. The apis muscorum, L. and some other species of humble-bees, cover their nests with a roof of moss. Mr. P. Huber having placed a nest of the former under a bell glass, he stuffed the interstices 
between its bottom and the irregular surface on which it rested, with a linen cloth. This cloth the bees, finding themselves in a situation where no moss was to be had, tore thread from thread, carded it with their feet into a felted mass, and applied it to the same purpose as moss, for which it was nearly as well adapted. Some other humble-bees tore the cover of a book with which he had closed the top of the box that contained them, and made use of the detached morsels in covering their nest.

"I once witnessed a similar instance of ingenuity in a tame dormouse which escaped out of its box, and contrived to conceal itself for two days in the corner of a pantry, close to where the bread was kept. In order to keep itself warm, it had bitten off with its teeth part of a damask napkin which it afterwards thoroughly carded with its feet, so as to leave no trace of threads or texture, but merely a mass of soft down, in the middle of which the fugitive was found imbedded and asleep.

"The instincts by which insects and animals provide themselves with food, or add to the comforts of their local position; the manner, for instance, in which cattle will take shelter during a storm, are all referable to sensations which we can partly understand; but we are less able to account for the wonderful geographical knowledge which they sometimes display. 
The bee, however devious have been its excursions from home, returns straight to the hive ; and the following well authenticated narrative places this geographical instinct in a strong point of view.

"In March 1816, an ass, the property of Captain Dundas, R.N. then at Malta, was shipped on board the Ister frigate, Captain Forrest, bound from Gibraltar to that island. The vessel having struck on some sands off the Point de Gat, at some distance from the shore, the ass was thrown overboard to give it a chance of swimming to land. The sea was running so high, that a boat which left the ship was lost : a few days afterwards, however, when the gates of Gibraltar were opened, the ass presented himself for admittance, and proceeded to the stable of Mr. Weeks, a merchant, which he had formerly occupied, to the no small surprise of this gentleman, who imagined that from some accident the animal had never been shipped on board the Ister. On the return of this vessel to repair, the mystery was explained; and it turned out that Valiante (so the ass was called) had found its way from Point de Gat to Gibraltar, a distance of more than two hundred miles, through a mountainous and intricate country, intersected by streams, which he had never traversed before, and in so short a period that he could not have made one false turn. His not having been stopped on the road was attributed to the circumstance 
of his having been formerly used to whip criminals upon, which was indicated to the peasants, who have a superstitious horror of such asses, by the holes in his ears, to which the persons flogged were tied." My letter is already too long.

Ever yours, Caroline. 


\section{LETTER V.}

FROM THE SAME TO THE SAME.

\section{DEAR EMILY,}

An ant-hill, in one of our most curious flowerbeds, has given us a great deal of trouble; but I do not regret it, because it has been the means of opening a scene of new wonders to my mind. Though Rachel was vexed to see her flowers covered with ants, yet she could not help watching their motions, which drew my attention to them. I was surprised to perceive, that, though they were generally without wings, some of them were furnished with four large ones. Rachel informed me that the winged insects differ in sex from those which have no wings, and are the parents of the community; that the greater number of them are a kind of neutral insect, that labours for the whole, by building their nests, and taking care of the young; with many other curious particulars, which would almost make one believe that they were endowed with reason, their instincts are so completely fitted to their wants. I passed the chief part of my morning in observing this busy multitude, and was particularly diverted with seeing several of them 
attack part of a peach that was lying on the ground. After having satisfied their appetites, they began to endeavour to remove the remainder to their city; but finding it too unwieldy for their powers, they divided it into pieces, and each one trudged off with its load. Soon after, another party seized a beetle, which was likewise a weight above their match: they had recourse to the former expedient of division. They sawed off his limbs, and carried him away in triumph; but not without other difficulties to subdue, for a small ridge intervened between them and their nest, which, like good pioneers, they levelled in one spot, and then proceeded with their treasure.

Rachel, perceiving the interest I took in their movements, proposed entertaining me with an account, selected from the papers of Mr. Smeathman, concerning the termites, an insect that abounds in the tropical climates, the habits of which are very similar to those of the ant, but still more wonderful. I enclose a copy of it for you, since you tell me that my letters have stimulated you to look into the book of nature. I think it must afford you much amusement. I am glad to hear, that, during your retreat in the country, you turn your attention to the same kind of objects. that now form my daily recreation, as it gives me some hope that the simple incidents of my rural life will not be wholly uninteresting to you. Rachel de- 
sires you will admit her into the circle of your friends, and ventures to unite her love with that of your affectionate

Caroline.

SOME ACCOUNT OF THE TERMITES, OR WHITE ANT OF TROPICAL CLIMATES.*

The attention of mankind is almost equally drawn to those creatures that are either particularly useful, and therefore brought under their observation, or so destructive as to render precautions against their ravages necessary. Rapacious beasts are not the only enemies against which men are obliged to contend. Insects of various species, that, from their diminutive size and apparent insignificance, appear, at first sight, to be incapable of injuring a creature that is endowed with reason, and is justly termed lord of the creation, are, nevertheless, able to cause him much inconvenience. For it has often happened that the farmer has been disappointed of his harvest, that a nation has been reduced to a scanty portion of food, and other calamities have arisen, from the depredations of in-

* The principal part of this account is taken from Mr. Smeathman. 
sects. Amongst the destructive classes may be ranged the termites, found in Africa and other warm climates, whose mischievous propensities are exerted in such an extraordinary manner, that no vigilance is a security against their attacks. It seems like a traveller's wonder to say, that a little insect, not larger than an ant, can undermine houses, destroy the supports and the woodwork, make its way through the floors, consume clothes, furniture, books, and every other article that is not made of stone or of metal. If the natives abandon a town composed of wooden houses, these industrious ravagers will clear it away so completely, that in two or three years a thick wood arises on the vacant space, and not a vestige of a house remains, unless any of the posts were made of iron-wood.

Some instances of their rapacity may be amusing to those not interested in the consequences; in order, therefore, to give a more exact idea of their operations, I shall relate the following circumstances. An engineer, who had been surveying a district in the Brazils, at going to rest, left his trunk on a table, as he supposed, in safety ; by the morning, he found his clothes and papers so far destroyed, that he was not able to collect a piece of either so large as a square inch.

At another time, a party of them discovered a cask 
of Madeira, and worked so effectually on the staves, as to let out the liquor.

The larger species (for there are several) chiefly make their approaches under ground, penetrating beneath the foundation of houses or stores, and rising again, either through the floors, or by entering the bottom of the posts that support the building; when they follow the course of the fibres, and make their way to the top, boring holes and cavities in different places as they proceed. Multitudes enter the roof, and intersect it with pipes, or galleries, formed of wet clay; which serve for passages in all directions, and enable them more readily to fix their habitation in it. They prefer the softer woods, such as pine and fir, which they hollow out with such nicety, that they leave the surface whole, after having eaten away the inside. A shelf or plank attacked in this manner looks solid to the eye, when, if weighed, it will not out-balance two sheets of pasteboard of the same dimensions. It sometimes happens that they carry this operation so far, on stakes in the open air, as to render the bark too flexible for their purpose; when they remedy the defect by plastering the whole stick with a sort of mortar that they make with clay; so that, on being struck, the form vanishes, and the artificial covering falls in fragments on the ground. In 
the woods, when a large tree falls from age or accident, they enter it on the side next the ground, and devour at leisure, till little more than the bark is left. But in this case they take no precaution of strengthening the outward defence, but leave it in such a state as to deceive an eye unaccustomed to see trees thus gutted of their insides. It is an extraordinary fact, that when these creatures have formed pipes in the roof of a house, instinct directs them to prevent its fall, which would ensue from their having sapped the posts on which it rests; but, as they gnaw away the wood, they fill up the interstices with clay, tempered to a surprising degree of hardness: so that, when the house is pulled down, these posts are transformed from wood to stone.

We have already seen that it is easier to shut one's door against a fox or a wolf, than to exclude these insidious enemies. On considering their destructive powers, incalculable numbers, and amazing increase, an inquiry arises in the mind of a casual observer. To what purpose was this insect created? and why was it endowed with instincts that lead it to be so injurious to man? But he who has habituated himself to believe in the infinite goodness of the Father of the universe, will hesitate before he presumes that any part of his works is absolutely mischievous or useless. He perceives that, in various other instances, apparent evil 
is the source of great benefit; whence he concludes that the same arrangement may prevail in this case; and, on further investigation, he discovers that, in the countries where the termites abound, vegetation is so exceedingly rapid and abundant, and counterbalanced by an equal celerity of destruction from natural or accidental causes, that, unless some indefatigable agents were provided to clear away every substance tending to decay, these fertile regions would become uninhabitable from the pollution of the air. In this point of view, this insect is a most valuable creature; and were it possible to annihilate the race, the consequences would be so baneful as to render their loss a serious calamity. It appears to be an invariable law of nature, that whatever has reached. perfect maturity should decay, and yield its place to fresh productions. This principle is as observable in the vegetable, as in the animal kingdom: thus, when trees, and even woods, are partly destroyed by tornadoes or fire, the instincts of many creatures impel them to consume the remainder, or prepare it for a speedy dissolution. None are more expert at this business than the termites; for, in a few weeks, they will divide and carry away the bodies of large trees, and leave a vacant space for a new growth of vegetable produce.

However troublesome to individuals, therefore, this 
little creature may be, its general use camnot be doubted. Its depredations on the labours of man may be called accidental, and are the result of its propensities, to promote the good of the whole.

It is time to describe its figure, and the instincts with which it is endowed for the purposes of its own preservation. These creatures have received the name of white ants, from their colour when first hatched, and the similarity of their habits to the common ant; though they greatly excel it in their structures and internal policy.

They live in communities, and build nests different in form, situation, and colour, according to the respective species. Mr. Smeathman, from whom this account is borrowed, has chosen the termes bellicosus, as being the largest and most easily observed, for the object of his particular description. The nests of this species are so numerous, that, in some parts, they are scarcely fifty yards separate, and of such magnitude that they might be mistaken for a village of the natives. They resemble a sugar-loaf in shape, and rise from ten to twelve feet perpendicularly above the ground: the outside shell may be compared to a dome, which encloses, and defends from the injuries of the weather, the interior of the building, which is curiously divided into apartments for different purposes, that will be better understood when the 
changes and habits of the insect are further described. The height of these hills, compared with the size of the architect, is vast, and their strength so great, that the wild bulls, which stand as centinels to the rest of the herd ruminating on the plain, generally take their place on one of them that is about half built. The commencement of this huge cone is a small turret or two, about a foot in height, and of a sugar-loaf shape : at a little distance, other turrets, of a similar kind, are raised; when, by increasing the number, and augmenting the size, the base of the building is covered with them ; the highest and largest remaining in the centre, till, by filling up the intervals between them, they are gradually formed into one large dome. When this is effected, they take arway the middle ones entirely, (except the tops, which, united, make the crown of the cupola,) and then apply the same clay to some other purpose.

In each community there are three orders of inhabitants, which are produced from changes similar to those of the silk-worm and several other kinds of insects. The working termites are about a quarter of an inch long, and are far the most numerous, being in the proportion of an hundred to one soldier, which is the denomination Mr. Smeathman gives to them after the first transformation: in this state they assume a different form, and are increased to the bulk 
of fifteen labourers. The organs of the mouth undergo a remarkable change, evidently adaptedto the new office of its owner. Whilst a labourer, a mouth formed for gnawing and taking hold of bodies was necessary, and it was accordingly well suited to that purpose; but when the insect is impelled by instinct to guard against the hostile attacks of an enemy, offensive weapons become requisite : it is now furnished with a formidable pair of piercers, or jagged forceps, capable of inflicting a painful wound. These forceps are placed in a strong, horny head, larger than all the rest of the body. The third metamorphosis is still greater : almost every part is altered from its original form, and four brownish, large, transparent wings, appear to enable the perfect termes to seek a convenient spot for a new settlement. The bodies of these are enlarged to the bulk of thirty labourers, and on each side of the head is a large round eye; but whilst the creature lived under ground, no eyes were visible. The greater number of the multitudes of these flies, which emigrate from the parent colony, perish in the course of a few hours, and become the prey of innumerable birds, reptiles, insects, and lastly, of man, as they are esteemed a nourishing, delicate food, that wants no other cookery than simply roasting before the fire. The few pairs that are so fortunate as to survive the 
various casualties that assail them, are found by labourers, (termites,) which, at this season, are running continually on the surface of the ground, on the watch for them. As soon as they discover the objects of their search, they begin to protect them from their surrounding enemies, by enclosing them in a small chamber of clay; where they become the parents of a new community, and are distinguished from the other inhabitants of the nest by the title of king and queen. Instinct is the principle which directs the attention of these labouring insects to the preservation of their race, in the protection of this pair and their offspring. The chamber that forms the rudiment of a new nest, is contrived for their safety, but the entrances to it are too small to admit of their ever leaving it; consequently, the charge of the eggs devolves upon the labourers, who construct nurseries for their reception. These are small, irregularly-shaped chambers, placed, at first, round the apartment of the king and queen, and not exceeding the size of a hazelnut; but, in nests of long standing, they are of far greater magnitude, and distributed at a greater distance. These receptacles for hatching the young are all composed of wooden materials, apparently joined together with gum, and, by way of defence, cased with clay. The chamber that contains the king and queen is nearly on a level with the surface of the 
ground; and, as the other apartments are formed from it, it is generally situated at an equal distance from the sides of the nest, and directly beneath its conical point. Those apartments which consist of nurseries and magazines of provisions, form an intricate labyrinth, being separated by small, empty chambers, and galleries, which surround them, or afford a communication from one to another. This labyrinth extends on all sides to the outward shell, and reaches up within it, to two-thirds, or more, of its height: leaving an open area above, in the middle, under the dome, which reminds the spectator of the nave of an old cathedral. Around this are raised three or four large arches, which are sometimes two or three feet high, next the front of the area; but diminish as they recede further back, and are lost amidst the innumerable chambers and nurseries behind them. The mechanical skill displayed in the contrivance of these chambers and passages, they being all arched so as to give support to each other, with the form of the hollow dome, adapted to collect a genial warmth for the tender young, which passes to the nurseries through openings suited to the purpose, must be attributed to instinct; for the termites are not endowed with any faculties superior to other insects, if required to act out of that line marked for them by Providence. In constructing their habita- 
tions, providing materials, guarding their infant progeny, collecting food, and defending themselves against their enemies, their instincts are admirable, and assume the appearance of order and design; but take one of them away from its fellows, and place it in a situation entirely new to it, it has no judgment to direct its conduct, or to extricate it from its unfortunate lot; therefore, its habits, however wonderful, (and they are truly so, as will be further shown,) are only the irresistible effects of impulse, and performed without a knowledge of the future, or a motive for choosing one mode of building in preference to another.

Great precautions are taken to keep the apartments dry; the area mentioned before forms a roof that is water-proof, and would carry off any water that might accidentally enter the dome, by a communication with some of the large, subterraneous passages that run at the base in various directions: these are lined with the same kind of clay of which the hill is composed, and ascend the inside of the outward shell in a spiral manner, winding round the whole building till they reach the top: they intersect each other at different heights, and open either into the dome immediately, or into the interior building. From every part of the large galleries issue small pipes, or lesser galleries, leading to different parts 
of the building. Many of these run under ground, descending into the earth three or four feet perpendicularly; from whence the labourers collect the finer particles, which, after being worked in their mouths to the consistence of mortar, become that solid clay of which their hills, and all their buildings except the nurseries, are composed. Some of these pipes extend to a vast distance, at least with respect to such minute creatures, being carried out more than an hundred yards from their main city. The large galleries are the great thoroughfares, and are well calculated by their spiral direction for that purpose ; as the termites have great difficulty in ascending a perpendicular, particularly the soldiers, probably from the weight and size of their head. If any part of the building happens to be upright, the inconvenience of ascending it is often obviated by a road, made like a flat ledge, directed in the manner of those roads which are cut on the sides of steep hills, to render the passage easier. It is probable that it is for the same convenience that they build a kind of bridge, of one large arch, which answers the purpose of a flight of stairs, from the floor of the area to some opening in one of the columns which support the great arches. This passage shortens the distance exceedingly to those labourers who have the task of carrying the eggs from the royal chamber to some of 
the upper nurseries; which, in the largest hills, would be four or five feet in the straightest line, and much more if carried through all the winding passages which lead through the inner chambers and apartments.

The king and queen, after once they are immured in their solitary cell, never quit it. The queen, like the queen bee, is the mother of the whole community. In this confinement she undergoes a considerable change; not so much by an alteration of form, as by an increase of size in a particular part. The abdomen, or lower body, stretches out like a bag, enlarging to a vast bulk, compared with the size of the labourers. Smeathman says he has seen this sack above five inches long. These queens are the parents of multitudes of eggs. Some of them have been observed to lay sixty in a minute, which, if uninterrupted, would amount to eighty thousand in one day of twenty-four hours. Instinct directs the labourers to watch the queen, in order to take away the eggs as soon as they are deposited, and to carry them to the distant cells, where they are hatched, and attended afterwards by these labourers, with the same care as most other creatures bestow upon their own progeny.

It is another peculiar instinct of all the different species, that the working and fighting insects never 
expose themselves to the open air, without the greatest necessity; but either travel under ground, or within such trees and substances as they destroy. If that necessity occurs, they makes pipes, of the same composition as their nests, varying the materials according to their kind: one species using red clay, another black clay, and a third a woody substance cemented with gums, as a security from the attacks of their enemies, particularly the common ant, which, being defended by a strong, horny shell, is more than a match for them, and when they can get at them, rapaciously seize them, and drag them to their nests, for food for their young brood. If any accident breaks these pipes, they repair the breach with all speed. Instinct guides them to perform their office in the creation, by mostly confining their attacks to trees that are beginning to decay, or such timber as has been severed from its root for use, and would decay in time. Vigorous, healthy trees do not require to be destroyed, and, accordingly, these consumers have no taste for them.

On opening one of their hills, a general alarm is excited. Some of the fighting insects immediately run to the place, and appear to survey the mischief, though they can only do so by feeling, as it may be remembered that they are blind: their quick 
mations express terror and rage, and they bite fiercely every thing within reach. By striking their forceps against the nest, they make a ticking kind of noise, which the labourers seem to understand, as they generally reply to it by hissing. After some time, if all is quiet, the fighters retire into the nest ; and the working insects fill up the chasm with fresh mortar, working with great regularity and dispatch. The soldiers have, by this time, disappeared, except here and there one, in the midst of several hundred labourers, who seems to overlook their work and hasten their operations by a stroke with his forceps, though he never assists them in their labour.

On renewing the attack, the same scene is repeated: but it is remarkable, that each class adheres to its own instincts; for, let the emergency be ever so great, the one order never attempts to fight, or the other to work.

Mr. Smeathman relates, that, as he was one day on a shooting expedition, he perceived a numerous body of a very large species of termites, that issued out of a hole, and marched rapidly forward, in two parties, chiefly composed of the working insects; though they were attended by soldiers scattered among them, as if to keep them in order. During their march, which seems to have continued some 
time, several of the fighting insects mounted up the plants which overhung the path the troop pursued, and placing themselves on the points of the leaves, which were from ten to fifteen inches above the ground, frequently tapped the leaf with their forceps, which produced a general hiss, and a quicker pace. After watching their progress for more than an hour, they began to descend into the earth, by two or three holes. It is remarkable that this kind were furnished with two conspicuous eyes, and, consequently, fitted for these excursions above ground.

It is not necessary to point out all the peculiarities of instinct of each distinct species; but it may be curious to observe the varieties of the form and situation of their nests. One kind forms upright cylinders of well-tempered black earth or clay, about three quarters of a yard high, and covered with a roof of the same material, in the shape of a cone, projecting on all sides beyond the pillar. After one of these turrets is finished, it is neither altered nor enlarged; but if the community becomes too numerous for the habitation, the foundation of another turret is laid, within a few inches of the first. These turrets are often increased to the number of five or six, at the foot of the same tree, in the recesses of the woods, Within, they are 
divided into a vast number of irregular cells, but by no means so varied and artfully disposed as the interior of the hills of the termes bellicosus.

Another species varies both as to the substance and situation of its nests. They are composed of small particles of wood, made into a sort of paste with the gums and juices of trees; and are frequently fixed between the arms of trees, often surrounding the branches at the height of seventy or eighty feet from the ground; being of a round or oval shape, and of a very large size.

The termites, as has already been said, abound in all tropical countries; but their huge nests are most numerous in places not fully cultivated. As far as relates to their own wants, and the particular office for which they are designed, their instincts are admirable, and afford a striking instance of the exact adaptation of the means to the end.

A more full account of their economy and internal management might have been given; but it is apprehended that enough has been shown to prove that this creature is amply endued with such an instinctive principle of action, as enables it to pursue its own interest in the most perfect manner, and to fulfil the destination of its Great Creator. 


\section{LETTER VI. \\ FROM EMILY TO CAROLINE.}

MY DEAR CAROLINE,

THE patience you have shown in your misfortunes, and the excellent use of your time in retirement, have made you a great favourite with my father and mother; as they flatter themselves that I shall profit by your example, and, in due time, become a very good girl. I hope so too; but I have a great deal to overcome before I can be half so amiable as you are. You are contented under the greatest disappointments, whilst the most insignificant trifle puts me out of humour. Yesterday I had set my mind upon taking a ride with a pleasant party of young people, but nothing would content my mother but that I should stay with her at home, to receive an old gentleman, who had engaged to spend the afternoon with her; because he is a philosopher, and your letter on instinct must be shown to him. I submitted with a very ill grace, and was some time before I could recover the serenity of my countenance.

Our visitor made me some amends for my disappointment, by a pretty anecdote* which he related, * Rev. John Hall's Travels in Scotland. 
as a proof that something like sagacity, superior to instinct, on particular occasions, excites animals to deviate from their accustomed habits.

"Whilst I was travelling in Scotland," said he, "as I was one day amusing myself with the objects within my view, on the road between Huntley and Portsoy, I observed two magpies hopping round a gooseberry-bush, in a small garden near a poor-looking house, in a peculiar manner, and flying out and into the bush. I stepped aside to see what they were doing, and found, from the poor man and his wife, that, as there are no trees all around for some miles, these magpies, several succeeding years, had built their nest, and brought up their young, in this bush ; and, that foxes, cats, hawks, \&c. might not interrupt them, they had barricadoed not only their nest, but had encircled the bush with briers and thorns, in a formidable manner ; nay, so completely, that it would have cost even a fox, cunning as he is, some days' labour to get into the nest.

"The materials in the inside of the nest were soft, warm, and comfortable; but all on the outside so rough, so strong, and firmly entwined with the bush, that, without a hedge-knife, hatch-bill, or something of the kind, even a man could not, without much pain and trouble, get at their young; for, from the outside to the inside of the nest, extended as long as my arm. 
"They fed the young brood with frogs, mice, worms, or anything living, within their power to subdue. It once happened that one of the magpies having seized a rat, which it was not able to kill, one of the young ones came out of the nest to its mother and the rat, while they were fighting on the outside of the bush, and assisted her to kill it, which they were not able to accomplish, till the father, arriving with a dead mouse, also lent his aid.

" These magpies had been faithful to one another for several summers, and drove off their young, as well as every one else that attempted to take possession of their nest. This they carefully repaired and fortified in the spring, with strong, rough, prickly sticks, that they sometimes brought to it by uniting their force, one at each end pulling it along, when they were not able to lift it from the ground."

Believing that the whole circle of naturalists at the Parsonage cannot find you such another pair of magpies, I send you the narrative-

And am, as ever, your affectionate

Emily. 


\section{LETTER VII.}

FROM CAROLINE TO EMILY.

\section{DEAR EMILY,}

Your friend's description of the artful contrivances of those ingenious magpies, would make ample amends for staying at home. The fondness of animals for their young is truly surprising; and when called forth by particular circumstances, seems to give them powers beyond the common limits of their faculties.

A few evenings ago, as I was enjoying a walk with my dear Rachel, she led me through some verdant meadows, covered with the sheep of a neighbouring farmer.* Our path lay within a hundred yards of a clear brook, formed by a small stream that descends from a mountain. Many ewes and lambs were feeding near us, but one in particular drew our attention by the singularity of its motions. She approached us, bleating very loudly, and, after looking pitifully in my face, ran off towards

* This anecdote is attested as a fact by Mr. Collet, in the Monthly Magazine for December 1808. 
the brook. At first we regarded her with a careless eye : but, on a repetition of the same actions, bleating still louder, and again running towards the water, showing an anxiety for us to follow her, by repeatedly looking behind her till she reached the brook, where she stood still, she excited more notice; and having watched her for some minutes, without being able to account for her behaviour, we continued our walk, and had nearly reached the gate that led into the next field, when she came running after us the third time, and seemed yet more earnest, if possible, than before. We then determined to follow her, in order to discover the cause of her uneasiness. As soon as we turned towards the rivulet, she ran with all her speed, looking frequently behind her. When we reached the brink of the stream, she peeped over the edge of a hillock into the water; looked up in our faces, as if to solicit our commiseration; and bleated with the most significant voice I ever heard from one of those creatures we call dumb. Judge of our surprise when, on looking over the brink, we perceived her lamb standing close under the hillock, with the water nearly over its back. Rachel ran to the farm-house for help, whilst I staid by the anxious mother to assure her of our assistance. The lamb was presently rescued from its dangerous situation, when its fond dam began to lick and suckle 
it ; looking up at us with pleasure, if not gratitude, and expressing her sensations by several cries, very different from those bleatings she had uttered in her distress.

The delight we felt was little inferior to that of this tender creature, whose maternal solicitude impelled her to a conduct that nearly approached to reason. Indeed, it is extremely difficult to fix the limit where instinct ends, and the reasoning faculty commences: so nearly interwoven are the gradations of being, that the distinctions are scarcely perceptible.

The farmer's wife was also well pleased at saving her lambkin, and entreated us to rest ourselves in her parlour, and partake of a bowl of raspberries and cream. We accepted her hospitable invitation, and were well entertained with her conversation, as she was qualified to give us much interesting information concerning the sheep. "Our old shepherd," said she, "has had long experience in his business: he can readily distinguish, by the cries of the mother, whether a lamb is lost by drowning, falling into a pit, or destroyed by birds or beasts of prey. In the two first cases, she runs about in a frantic, disordered manner, utters a wild sort of cry, comes hastily back, and will look into the hole or pit where it is. If the lamb be carried away, her behaviour is still more disordered: she runs about from one of her neighbour's lambs to another, and the 
tremor of her voice shows the perturbation she suffers. Sometimes she expresses her woes in a long, melancholy tone; at other times, her bleat is a wild, inarticulate strain, expressive of her anguish. There are few creatures," continued she, "that defend their young with more warmth, as long as they are able, than the sheep; though, at other times, they are remarkable for the meekness of their spirit. When we put them to their mothers again after weaning, each sheep knows her own lamb, and ever after associates with it."

Upon this, I inquired how it was possible she could know that the lambs were recognised by their mothers : for to me all sheep have the same countenances. "So far from that," replied the farmer's wife, " the shepherds know every sheep of the flock;; and my husband remembers an instance of a man being hanged for sheep-stealing, at Bury St. Edmund's, on the oath of the prosecutor, who swore to the countenance of the sheep." We all agreed that we should be sorry to deprive a fellow-creature of life on a circumstance that appeared to us so uncertain; yet it was admitted as sufficient evidence in a court of justice. Rachel remarked, that though the innocent and gentle disposition of the sheep rendered it an amiable animal, she thought it had but little intelligence or attachment. The farmer's wife said that they were not so deficient 
in either as they appeared to those not conversant with them; as she could prove by two stories she had heard from their shepherd, who was a Scotchman, and had witnessed the facts.*

"No animal," resumed she, "is more attached to that spot of earth on which it was reared, than the sheep. A ewe that was driven from Scotland into Yorkshire, made her escape, and after passing through towns, crossing rivers, \&c. revisited her native spot in the hills of Annandale. Another from Perthshire came back to Hundishope, a store-farm nearly twenty-three miles distant from Edinburgh. When she reached Stirling, it was fair-day: she durst not venture through the town amongst the populace, but rested herself at its north side till the fair dispersed, and came through late in the evening."

Our repast being finished, we thanked our kind hostess for our entertainment, and returned by another path, along the sea-shore, leading over the crag of a projecting rock, which commanded a most beautiful view of the setting sun, gradually sinking into the ocean, and tinting the waves with the richest colours. Whilst I was enjoying the extensive prospect, Rachel exclaimed: "Observe, beneath, that crowd of fishermen! they seem to have found something curious in the water; let us descend, and see what it is !"

* Repertory of Arts. 
We accordingly did so, and found a worm of prodigious length, perhaps more than twenty feet long, and not thicker than a crow-quill. The fishermen said they had seen some of the same species as many yards in length; but we scarcely gave them credit for their assertion. Rachel knew, at the first glimpse, that it was a gordius marinus; and said that its power of contraction and extension was so great, that it could not be measured: for that Mr. Palmer had put one of eight feet, alive, into spirits, and it instantly shrunk to one foot, but increased twice its former size in bulk. Whilst we were looking at it, it twisted itself into an indescribable variety of convolutions, and in its motions frequently described the most graceful swells imaginable. I wanted to give the men a trifle to carry it home; but Rachel said it was scarcely possible to preserve it in its natural state, for, if suffered to die in sea-water, one part will decay, whilst the other is alive; and so sensible is this creature to anything contrary to its nature, that even fresh water occasions an immediate contraction.

Upon our return home, we gave an account of the objects that had excited our attention; when Mrs. Saville, who often contrives to draw moral instruction from trifling circumstances, remarked, that the pleasure of this huge worm seems to consist in its

* Transactions of the Linnean Society. 
agility, and perpetual change of form, which probably arises from a back-bone of balls and sockets, like the serpent tribe. "This species of enjoyment," said she, " is wholly animal; yet it is adapted to the class of existence to which the gordius belongs. The gradations of enjoyment are as regular as the order's of creatures, or the degrees of intellectual capacity. Man is superior to every other inhabitant of this globe: his rational powers enable him to turn his attention on the objects by which he is surrounded; he can investigate their structure, their habits, and the laws that direct them to pursue their own good; and he alone can refer the arrangement and government of this beautiful world, with all the creatures that dwell on it, to that Great Source of goodness and intelligence that created it."

Rachel, with ready recollection, immediately applied those lines of Burns, in confirmation of her mother's assertion that every creature has its own peculiar happiness.

The partridge loves the fruitful fells;

The plover loves the mountains :

The woodcock haunts the lonely dells;

The soaring heron the fountains.

'Thro' lofty groves the ring-dove roves,

The path of men to shun it;

The hazel-bush o'erhangs the thrush;

The spreading thorn the linnet. 
Thus, ev'ry kind their pleasure find ;

The savage and the tender:

Some social join, and leagues combine;

Some solitary wander.

This conversation was scarcely finished, when Rachel, with more earnestness than usual, inquired whether Sarah had taken in her linnets; for she that moment recollected that she had carelessly left them abroad, when she went from home. "They are safe," replied Mrs. Saville ; "but, my dear girl, you have been on the point of losing them both." Rachel's cheeks flushed deeper red than usual at this intelligence. "You had left Robert at liberty," continued Mrs. Saville, "and by some accident the fastening of Henry's cage was undone; and just as Fanny was bringing home the cows across the lawn, she perceived him at the cage-door, ready to join his friend. She hastened towards him, before he had time to escape."

In order to make this account intelligible, I must tell you the history of Rachel's linnets. They were caught by a nephew of her father's, when a schoolhoy, who is since dead; and, being great favourites with their master, Rachel took them under her protection.* These birds are very remarkable for an attachment to each other, though they have not been

* Dr. Lettsom related these circumstances in the Monthly Magazine. 
brought up together, and are both of the male sex. They have now been kept several years, and their friendship appears to be strengthened by time. The first tokens of their mutual regard were observed in the early part of their acquaintance: when one sang; the other joined it ; and, at night, each slept on that side of the cage which was nearest his friend. At length their attachment was more fully ascertained, when they were set at liberty whilst their cages were cleaned. One of these affectionate birds took the opportunity of flying to the other's cage, and they were afterwards occasionally indulged with enjoying each other's company in the same cage; when they always expressed their high gratification, by fluttering towards each other, joining their bills together, and each gently pecking the tongue of his friend by turns. After some time, their young master ventured to allow one of them to fly abroad in the open air, whilst the cage of the other was hung on the outside of the window as a pledge for the return of his friend. Rachel grants this indulgence sometimes to one and sonetimes to the other. They both appear greatly delighte. vith the company of the wild linnets, with whom they sport for several hours together; but no temptation can allure them to forsake each other. As soon as the hour of rest approaches, they return to the empty cage, which is placed near the other. Were both 
allowed to go abroad together, it is not very likely they would ever come home: but so strong is their attachment, that they prefer captivity to separation. Should death divide these fond friends, it is supposed that the survivor would soon die with grief.* They were named Robert and Henry, after two favourite schoolfellows of Rachel's cousin; and, as he valued them highly, she has tended them with great care since his death.

If Rachel had not such a particular motive for keeping these birds, they would have been set at liberty long ago ; for she disapproves the cruel custom of confining birds in cages.

I hear the summons for dinner, which obliges me to put an abrupt termination to my letter. Adieu.

Caroline.

$\therefore \quad$ * Which actually happened to Dr. Lettsom's linnets. 


\section{LETTER VIII.}

FROM EMILY TO CAROLINE.

\section{MY DEAREST GIRL,}

I ADMIRE your friendly linnets, and think they should have been named Damon and Pythias, after the celebrated friends of ancient story. They prove, at least, that birds have affection, if they have not reason. But I can assure you that they are capable of attachment, not only to their own species, but also to those who feed them, and to the place where they have been sheltered and nourished.

We are apt to consider sparrows as stupid, and regard them with an unfavourable eye because they eat a little of our corn ; but a friend of my mother's related an instance of the sagacity of one she had brought up tame from the nest, that really astonishes me; yet, as she is a person of strict veracity, you may believe it to have happened exactly as she told it.*

This lady lived at Fulham at that time; and when she went, for the winter, to her house in London, which was situated near the Thames, she conveyed

* This anecdote is related on the authority of Mrs. Powell of Tottenham. 
the sparrow, having covered his cage, in the carriage. After some months, the window of the drawing-room was one day left open, and, as the bird was suffered to fly tame about the room, it took its flight, and was lost without hope of recovery.

About ten days after this circumstance, she had occasion to send a servant to Fulham, who told the maid left there, of the unfortunate accident of losing the sparrow, and his mistress's concern on the occasion. Upon which she observed, that for a day or two a sparrow had come constantly into the kitcten, and, with unusual familiarity, had placed itself upon the chairs and dressers. It proved to be the sparrow that had escaped from London, and had been a week finding its way to Fulham; as it had taken flight in quite a contrary directiore, the window looking towards Northumberland Gardens.

The same bird, the following spring, formed an attachment to a female of his own kind, and made a nest ; and, in order to gather materials for it, frequently visited the house, for bits of rag or thread, which he carried away in his beak. Sometimes he brought his wife into the parlour, and once was accompanied by all his little ones; but they were soon alarmed, and flew away. When they were able to take care of themselves, he returned to his kind protectress, and lived in the room as before. This faithful creature 
met with an unfortunate end, being accidentally crushed in a window-shutter.

Can your friend Mr. Palmer tell me by what sense this bird was guided to the spot whence he was taken? It could not be sight, for he was conveyed from one place to the other in such a manner that he could not possibly trace his way. It is not likely that the sense of smelling could have retained an influence for so many months. Nor can I devise any known quality with which birds are endowed, that can account for it. You see that, in imitation of you, I am becoming a naturalist; and shall add to your store of curious anecdotes of animals, whenever I meet with any deserving your notice.

You remember that my father is a great sportsman, and is generally accompanied in his shooting expeditions by Mr. Craven, a respectable farmer, who is one of his tenants. When they return from the exploits of the day, they generally engross all the conversation with relating their sanguinary achievements, or the hairbreadth escapes of the poor animals, who owed their preservation, probably, more to the bad aim of the marksman, than to the swiftness of their wing. My patience is often exhausted by being obliged to listen to subjects in which I feel so little interest, and which too often savour of cruelty; for I can take no pleasure in the needless destruction of the 
meanest creature that breathes. When we are at Woodlands, Mr. Craven is a frequent guest. Though his manners are not elegant, he is a man of observation and good sense, and has availed himself of the advantages of a country life, to become acquainted with the habits of many animals that live wild around him, as well as those domesticated in his farm-yard; and, as he has no reluctance to display his stock of knowledge, when admitted into our circle, I was so fortunate as to give a turn to the history of leaping over five-barred gates, and similar feats of dexterity, by inquiring the means used by the poor victims to elude the pursuit of their enemies. This question led to the modes of defence peculiar to different species of creatures, and the alarm they give to their companions at sight of their natural enemies.

The appearance of a hawk excites a note expressive of fear in a hen turkey followed by her brood, which is learnt by the young ones, and afterwards applied by them to the same purpose.

A rabbit apprized of danger, will convey the intelligence to her neighbours by thumping in her burrow with her hinder feet.

Rooks, whilst they feed, are guarded by a watchman, who perches on one of the tallest trees near them, that he may perceive an enemy at a distance, and expresses alarm at the sight of a man with a gun. 
Fieldfares corne to this island from Norway, in winter, for the comforts of a milder climate, and the berries in our hedges: they associate in flocks, and, like other birds who live in society, have a guardian to watch over their safety. He is generally placed at the extremity of a bush, rising on his wings; and, if alarmed, gives a peculiar and loud note of terror. The lapwing, after warning her young to conceal themselves, by a note intelligible to them, upon the approach of men or dogs towards her nest, appears more terrified than before, in order to deceive those she fears.

Partridges are still more artful: they pretend to limp and scream before their pursuers, till they have withdrawn them from their young.

In other instances, Nature has furnished animals with peculiar weapons of defence. The petrel, which is a bird remarkable for fat, has the singular capacity of squirting oil from its bill when it has no other means of annoying its enemy.

The voluntary power of electrifying an enemy, is possessed by the gymnotus electricus in a surprising degree, and is an irresistible defence against those whom it attacks. It is a native of the river Surinam, in South America, and is said to exceed twenty feet in length. It can kill a man, when irritated. The same faculty enables it to seize its prey, by first be- 
numbing it, and then devouring it before it is recovered. Mr. Hunter has shown, that the organs productive of this wonderful accumulation of electric matter are so divided by membranes as to compose a very extensive surface, and are supplied with many pairs of nerves, larger than any other nerves of the body.

The torpedo enjoys a similar power in a less degree; and some other fishes likewise.

Here is a mode of defence of a very peculiar kind ; a proof, amongst many others, that Nature uses a variety of means to effect the same purpose. The echinus, or sea-hedgehog, is differently armed, with moveable spines, resembling those of the land animal of the same name. Some sea-fish are defended by the protuberances on their shells, which serve them for a fortification. The instincts of the eclinus teach it to foresee tempestuous weather, and it is furnished with the means of resisting its effects. It fastens itself firmly to plants or other substances, at a great depth, by means of tendrils that resemble the horns of snails. Twelve hundred of these cords have been counted in one animal. When afloat, they are contracted between the bases of their spines.

The sea-blubber, or sea-nettle, would be a most defenceless animal, being little more than a lump of transparent jelly, and very slow in its motions, were it not for a caustic quality, that blisters the flesh of 
those that touch it, and causes a painful degree of inflammation.

Fear is, no doubt, a great defence to those creatures that owe their safety to flight, though it seems that they often acquire a sense of danger from experience; for M. Bougainville relates, that in the Falkland Islands, the fowls settled on the heads and shoulders of his people, and the quadrupeds ran about their feet. Such a scene would remind one of the Garden of Eden.

I have now given you the chief points of information which I drew from my sporting acquaintance, who has wandered far beyond his own sphere; hoping to receive from you further hints on this amusing topic.

The Misses Ormond, who, you may remember, were sometimes admitted into our parties when you were at Mr. Campbell's, are come to pass the summer within a mile of Woodlands, in consequence of a large estate, with a title, coming unexpectedly to their father, through the accidental death of a very distant relation; who, at the early age of twenty-four, was killed by a fall from his horse in a fox-chase. It is a pleasant walk to Belvoir Lodge, and I have called upon them frequently, hoping they would be agreeable companions in the retirement of the country; but their former inclination to pride and airs of consequence is so much increased by this sudden elevation, that I am sometimes inclined to relinquish them, 
were it not that I have the vanity to hope I may lead them to a degree of improvement in their tastes and sentiments. The other day, Charlotte, with the most provoking coolness, inquired whether I knew what was become of you. I showed her our correspondence. She smiled, and said you were very romantic; but though she pretended to feel contempt for the obscurity of your present mode of life, she could not deny some praise to the magnanimity you have shown in adversity.

Continue, my dear girl, to instruct me by a recital of your occupations and amusements: you have already wrought a material change in the mind and sentiments of your affectionate friend,

EMILY. 


\section{LETTER IX.}

FROM CAROLINE TO EMILY.

DEAR EMILY,

Your anecdotes have amused us extremely, and led us to propose the subject of the modes of defence used by animals, as well as the weapons given them for that purpose, to Mr. Palmer for his next lecture; but, as he requires time to collect matter for our instruction on this curious topic, I shall dismiss that for the present, and relate a remarkable instance of ingenuity, seeming to arise from reflection in two goats, that happened lately near this place.

On the crag of a high rock, overhanging the sea, are the ruins of an ancient castle, once the seat of feudal grandeur, but now serving only to heighten the romantic wildness of the prospect. One of the bastions remains nearly entire, along which, at a great height, runs a projecting ledge, perhaps a foot wide. A couple of goats, grazing about the ramparts, by some means got down upon the ledge, and one of them advancing till it arrived at an angle, was enabled 
to turn; but, in its way back, met its companion, which produced a most perplexing dilemma, for it was impossible to pass each other. Rachel and I having wandered near these ruins, in order to gather some wild strawberries, which grow in the neighbouring woods, arrived at this critical moment, and were witnesses of their distress, without being able to assist them. The poor animals were sensible of their unfortunate situation, and uttered the most doleful cries. After anxiously viewing them for some minutes, we ran to some cottages at a little distance, to see if it were possible to discover any means of extricating them. Men, women, and children, led by curiosity, followed us to the spot; but they could only sympathize with the poor animals, without daring to attempt their relief, lest they should be precipitated on the rocks beneath. Many plans were proposed, but all ineffectual. After a considerable time, when hope had almost given place to despair, one of the goats was observed to kneel down with great caution, and crouch as close as it could lie; which was no sooner done, than the other, with great dexterity, walked over him, and they both returned the way they came, in perfect safety.*

* This circumstance actually happened on the ramparts of Plymouth Citadel, and is attested by Captain Martin. 
Did not this look like a concerted scheme between these two goats to get free from the terrible apprehension of starving on this precipice? You may believe, that a general joy was felt at the success of their stratagem, and no small surprise at the contrivance. To you, who have probably never seen a goat but in a tame, domestic state, the story may seem improbable; but it would more easily gain credit from an inhabitant of these mountainous regions, who must often have observed the wild goats climb with rapidity and elegant ease to the highest pinnacle of the most rugged rocks; and when they have attained to a height that seems adapted only to be the restingplace of the towering eagle, frisk about as carelessly as a wanton child would do on a grass-plat, and then look down without fear upon the vales below.

No animal more strikingly demonstrates the harmony that prevails between the instincts and inclinations of the inferior classes of creation, and the places destined for their abode, than the goat. Nature has formed it to inhabit wild and uncultivated regions, where nothing grows but a few alpine mosses and lichens, a little wild thyme, or scattered blades of mountain grass : but these are the very food the goat delights to regale upon.

There is another coincidence that is too remarkable to be ascribed to chance: their hoofs are calculated 
exactly to secure them on the brink of the steepest precipices; they are hollow underneath, with sharp edges, like the inside of a spoon, which prevents them from sliding off the rocky eminences they frequent. A foot that is so nicely adapted to the purpose required, by an animal whose native character leads it to climb amongst rocks and declivities, would have been useless or inconvenient to a creature which grazed on a level. Its disposition, also, accords with the suppleness of its limbs and the agility of its motions: always restless and active, it walks, stops short, runs, skips, jumps, advances, retreats, exposes itself to view, then hides itself behind a thicket, or flies out of sight; and all without any apparent motive but the pleasure of changing from one pasture to another. But with so much caprice, they seem to have a tenderness that is amiable; they soon become tame, and will feed out of the hand of those to whom they are attached. Buffon says they will easily suffer themselves to be sucked, even by young children : hence, the fables of heroes nourished by a goat. $\mathrm{He}$ adds, that adders, and that strange-looking bird, the goat-sucker, fasten to their teats during the night, and deprive them of their milk.

They are very numerous in this country. Mrs. Saville often makes cheese of goats' milk; and the 
flesh of the kid is thought preferable to lamb. The haunches are frequently salted, and used instead of bacon. But I cannot say that I admire the flesh of the old ones, as it has a strong, peculiar taste.

Do not suppose that I lead the life of a recluse: though at so great a distance from the metropolis, we have our festivities. If they are of a different kind from balls and masquerades, they are, at least, full as innocent, and sometimes leave a tranquillity and satisfaction on the mind that can only be procured from those pleasures that consist more in making others happy than in present self-gratification. Mrs. Saville, whose principal study is to do good, promotes the welfare and establishment in life of those girls who have been brought up in her school, after they have left it. If they form a matrimonial connexion that meets her approbation, she either gives them a wedding dinner, or supplies them with some useful article towards house-keeping, according to the circumstances of the party. You will, perhaps, think this liberality very inconsistent with the narrow fortune to which I formerly told you she was limited; but, by denying herself every superfluous indulgence, she has always something to spare for the wants of others, which she loves to relieve in that delicate manner that 
consults their feelings as well as their necessities.

Last week a young woman, who, from the excellence of her conduct, had been one of her favourite scholars, gave her hand to the son of a small farmer in the neighbourhood. As his relations were numerous, and it is customary to invite every branch of the family, and all intimate acquaintance, to assist at the joyful solemnity, it was decided that the feast should be celebrated at the house of the new-married couple, and that Mrs. Saville should only furnish the materials for the dinner, and honour the company for an hour or two with her presence, attended by myself and Rachel, who performed the office of bridemaids. Mr. Palmer united the happy pair in the holy bands of wedlock; and we paid a visit to the bride, as soon as we thought she had had time to put her domestic affairs in order, and had the satisfaction to see the good effects of Mrs. Saville's instructions. We found her busily employed with her spinning-wheel at the door, and every part of her dress perfectly neat, though free from any attempt at finery. She appeared much pleased with this mark of notice; and, with a sort of conscious pride, showed us every corner of her house, which might serve as a pat- 
tern for others in the same station. Though humbly furnished, every thing was in its place: even the clothes in her drawers were arranged in the neatest manner. Mrs. Saville frequently makes a round of such calls amongst her poor neighbours, that she may know who best deserves her bounty, and in what manner she can most properly relieve their wants. On these occasions, she gives her advice where she sees it necessary; but so kindly does she mix encouragement with reproof, that she renders even this welcome. These visits are considered as proofs of her favour, and every one is eager to obtain them. If she passes a cottage door, the owner is certain of having incurred her displeasure; and so sincerely is she beloved, that few are happy till they have regained her esteem. In all times of difficulty, they apply to her for counsel and help: you would be much pleased to see with what condescension and sympathy she listens to their complaints, soothes their sorrows, and leads them, with a gentle hand, from error to the right way.

Though rigidly exact in her own conduct, she is always ready to soften the faults of others; for she often says, had she been exposed to the same temptations, with so few advantages, she might have been guilty of the same : and so far from assuming to her- 
self any praise, she frequently remarks, that much of the applause the best receive, is because their perverse inclinations are not seen.

Can I live with such a woman, and not endeavour, at a humble distance, to imitate her virtues? My misfortunes, as they appear in the eye of the world, have been the greatest blessing that has been bestowed on your happy

Caroline. 


\section{LETTER X.}

\section{FROM THE SAME TO THE SAME.}

\section{MY DEAR EMILY,}

Mr. Palmer came in this morning after breakfast, to tell us of a remarkable circumstance that had happened in a large room belonging to the parsonagehouse, which is an ancient building.* A very unpleasant smell had been observed for some time in this apartment, for which it was not easy to account, when, having occasion to employ a carpenter to make a small opening in the wainscot, in order to repair it, out flew such multitudes of bats as really darkened the place; according to Mrr. Palmer's belief, not less than two hundred. It appears that they had crept in, through a small crevice between the bricks, on the outside of the wall, and so concealed themselves in the cavity between the wall and the wainscot. How long they had been there is uncertain; but long enough to bring forth and half rear their young, who flew after their parents with that fond attachment that is so striking amongst the various tribes of animals. Some of them,

* A circumstance, in all respects similar, happened, a few years ago, in a very old house at Tottenbam High Cross. 
which were in the act of sucking when they were alarmed, clung to their mothers' breasts without letting go their hold.* The windows being open, many escaped; but a great number were buffeted to death by the servants, who were collected together by the cries of astonishment uttered by the carpenter, who was really terrified at such an unusual concourse of living creatures, that proceeded, as if by enchantment, from the wall.

Mr. Palmer brought one of those that had been killed, in his pocket, that we might examine the peculiarities of its structure; especially its wings, which consist of an extremely thin, light, delicate membrane, that extends from one shoulder entirely round the body to the other, and connects the fore and hind legs together. From the delicacy of its texture, and its flexibility, the creature can fold this membrane into a very small compass when it inclines to rest; but when its wants impel it to take flight, it has, likewise, the power of stretching it out like a sail, to a considerable extent. From the skeleton of this wing, when divested of its covering, it plainly appeared that the principal bones resemble so many very long fingers; the fifth, which is much shorter than the rest, may

* I do not vouch that this was observed amongst the bats discovered at Tottenham; but Mr. Bingley mentions it as a habit of the race.-See British Quadrupeds, pp. 33, 48. 
properly be called the thumb, and being armed at the end with a sharp and hooked claw, enables the bat to adhere closely to walls, the clefts of rocks, and such like places, where they remain in a torpid state during the winter, hanging by their claws with their heads downwards, and their wings wrapped round them, probably for warmth.

Mr. Palmer, perceiving that we were desirous of knowing more of the habits of these curious animals, which partake so largely of the nature of both birds and beasts, related some experiments that had been made with them. A gentleman* kept one of them for the purpose of examining it more particularly. He offered it a common house-fly when it was asleep, and, in order to rouse it, touched its nose with the fly. The bat, sensible that its prey was at hand, made a kind of smack with its mouth, then threw itself suddenly forward by his hind feet, and immediately devoured the insect. A large blue flesh-fly was afterwards presented to it, and was received in the same manner as the former one; but this fly was so large, that the bat was obliged to have recourse to contrivance, to get it into its mouth. He raised himself somewhat higher than usual on his fore legs; bent his head, with great dexterity, under his belly, and forced the fly into his mouth, by thrusting it from side to side against that

* Mr. Bingley. 
part of the membrane which extended between the two hind legs; by which artful means he gained his point, and swallowed his prey without further difficulty.

Spallanzani, a naturalist of great eminence, discovered that bats, when perfectly blinded, and afterwards set at liberty, had the extraordinary faculty of guiding themselves through the most complicated windings of subterraneous passages without striking against the walls; and that they avoided, with great nicety, cords, branches of trees, and other obstacles, placed, by design, in their way. He was so much at a loss to conjecture how this was effected, that he attributed it to some unknown sense bestowed upon this creature for its security. But Mr. Palmer very ingeniously attributes it to an extreme delicacy of feeling in the wing, which presents to the air an enormous surface in proportion to the size of the animal, and is covered with an exquisitely fine net-work of nerves. He therefore supposes that, in the action of flight, the air, when struck by this wing, so well adapted to its office, impresses a sensation of heat, cold, or resistance, which directs the bat to avoid any object that would obstruct its flight; just as you may have seen a blind person perceive a door, or a wall, by the difference of the resistance of the air, without the assistance of touch.*

* See Bingley's British Quadrupeds, p. 35. 
It is a remarkable propensity of various kinds of animals to fall asleep in winter, and to remain in a state of torpidity till the spring returns; insensible to pleasure or pain, and preserving their existence without the refreshment of food, partly from not exhausting themselves by action. Mr. Palmer's reply to my inquiries on this interesting subject so well deserves your attention, that I shall repeat it. - "The wise provision of the Creator, for the comfort of every race of creatures, is so admirably adapted to their wants, and so convincing a proof of his providence, that I am happy," said he, "to seize every opportunity of displaying it to you, my young friends, in its proper point of view. The torpidity of the bat leads me to say, that the same contrivance prevails, not only amongst many other animals, but is extended also to vegetables. Your own observation must have shown you, that in all those that survive the winter, there is a living principle that resists the strongest frosts; the effect of these only occasioning disease in them, or, if I may apply the term, putting them asleep. Our native trees lose their leaves in winter, whilst their stems remain uninjured. Many of our herbaceous plants lose their stalks, though their roots retain their functions. There are plants still more robust, which, after their roots have been frozen in the ground, the frost having penetrated several feet beneath their ra- 
mifications, revive, notwithstanding, at the return of spring. May not this stagnation of the operations of the fluids of these plants be justly compared with the dormant state of the torpid animals, to which we will now turn our attention? We see," continued he, " the ant fall asleep in a very slight degree of cold; and the common fly does the same, with every appearance of being dead. Nor are these, by numbers, the only insects subject to this lethargic sleep. Quadrupeds have frequently the same propensity. In dormice, marmots, and many other sleepers, life appears to be suspended when cold weather approaches. This suspension of the vital powers is so complete in some of the species, that their heart ceases to beat for whole months. The snail and the toad undergo the same stupefaction. Several serpents exhibit a phenomenon still more surprising: they can bear to be frozen to so great a degree as to become brittle, and die if they happen to be broken in this state; but if they be left unmolested in their holes, into which the warmth of spring penetrates very gradually, they revive, and give proof that they were not dead. Is it not a striking mark of creative wisdom, that, in all these tribes, this change takes place in the season when their food begins to fail-when the fruit and herbs on which they feed disappear? After having prepared them by an increase of fat, occasioned by the 
temporary abundance of summer, and in this fat supplied them with a narcotic to incline them to sleep, as well as food to support them while it lasts; and that at the same time that these little devourers are laid asleep, and, from their concealment in their hidingplaces, they cease to afford prey to the larger devourers, whom they serve for food, these, in their turn, also lose thought and motion. Those that would be deprived of food, by the snow covering that which they feed upon, sleep till the snow melts, and a little longer. Perhaps, for a similar reason, the white bear, which lives by fishing on the sea-shore during the summer, and on the islands of ice in autumn, does not fall asleep till the ice, united, thickened, and raised too high above the water, is no longer the resort of the seal. As the means of subsistence continues longer, a much severer degree of cold is requisite to deaden, in this animal, the appetite for seeking it, than in the black bear, which is a great devourer of honey and vegetables. Still less cold can the brown bear endure, which lives on animals that winter drives early into their retreats.

"This exact correspondence between the inclination to eat, and a supply of food, cannot be attributed to blind chance or accident, but to the arrangement of an All-wise Intelligence, that has fitted all the parts of the universe to each other; and, in the races of ani- 
mals now under our notice, has ordered that hunger should cease when famine would take place, as a means of prolonging their existence, and preserving them from starving."

The dinner-bell rings.

Believe me,

Your sincerely attached

Caroline. 


\section{LETTER XI.}

MY DEAR FRIEND,

When I was in Scotland last year, an anecdote I heard of a drover's dog so fixed my attention, that I was induced to take some pains to authenticate it ; and, in doing so, acquired so much fresh information, and so many surprising details of the shepherd dogs in that country, that the whole species have risen considerably in my estimation, and I have imbibed a respect for their superior powers that man himself does not always excite. Among the mass of anecdotes I collected, I will select such as will most illustrate our subject. I must begin by remarking that there are no species of animals so varied in their nature and propensities as the shepherd's dog; and these propensities are preserved inviolate in the same breed from generation to generation. Some kinds will manage sheep close at hand admirably; others excel in gathering sheep from the hills-will turn them this way, and that, as far as they are commanded, or can see the motion of their master's hand or hear his voice. The good qualities of some consist in the perfection of their 
social intercourse. A very singular feat is related* of a dog belonging to John Graham, late tenant in Ashesteel. A neighbour came to his house after it was dark, and told him he had lost a sheep on his farm; and that, if not recovered before the morning, the case would be hopeless. The night was pitch-dark, which was the cause of the man's losing his ewe. John went with him, accompanied by his dog Chieftain; and having made the man point out the very track that the sheep had taken, he called the dog to his foot, and pointing with his finger to the ground, said, "Fetch that, I say, sir ; bring that back-away." The dog scented slowly about on the ground for some seconds, but soon began to mend his pace, and vanished in the darkness. "Bring her back-away, you great calf," vociferated John with a voice of exultation as the dog broke to the hill; and as all the best dogs perform their work in silence, nothing more was seen or heard for a long time. While the men were waiting, the conversation turned on the small chance there was that the dog would find the ewe, for it was agreed that she must long ago have mixed with the rest of the sheep on the farm. How that was, no man will ever be able to decide. At the end of about half an hour, the trusty animal brought the identical lost sheep to the expecting party; which

* Hogg's Shepherd's Calendar, p. 297 ; from which most-indeed all the following singular anecdotes are taken. 
the man took on his back, and went his way rejoicing. John called him by all the ill names he could think of ; which the dog seemed to take in very good part. Such language seemed to be his flattery to his dog.

Mr. Hogg relates of his own dog, Sirrah, feats yet more astonishing. I will give it you in his own words, or otherwise the narrative would lose much of its native energy and grace.* "I was sent to a place in Tweeddale called Stanhope, to bring home a wild ewe that had strayed from home. The place lay at a distance of fifteen miles, and my way to it was over steep hills, and athwart deep glens; there was no path, and neither Sirrah nor I had ever travelled the road before. When I left the people of the house, Mr. Tweedie, the farmer, said to me, 'Do you really suppose that you will drive that sheep over these hills, and out through the midst of all the sheep in the country?' I said I would try to do it. 'Then let me tell you,' said he, 'that you may as well try to travel to yon sun.' Our way, as I said, lay all over wild hills, and through the middle of flocks of sheep: I seldom got sight of the ewe, for she was sometimes a mile before me, sometimes two: but Sirrah kept her in command the whole way; never suffered her to mix with the other sheep, nor, as far as I could judge, ever to deviate twenty yards from the track by which

*. Shepherd's Calendar, p. 302. 
he and I went the day before. When we came over the great height towards Manor Water, Sirrah and his charge happened to cross it a little before me : our way lying down steep hills, I lost all traces of them, but still held on my track. I came to two shepherds' houses, and asked if they had seen anything of a black dog, with a branded face and long tail, driving a sheep? No, they had seen no such thing; and besides, all their sheep both above and below the houses seemed to be unmoved. I had nothing for it but to hold on my way homeward; and at length, on the corner of a hill at the side of the water, I discovered my trusty coal-black friend sitting with his eye fixed intently on the burn below him, and sometimes giving a casual glance behind to see if I was coming : he had the ewe standing there, safe and unhurt. When I got her home, and set her at liberty among our own sheep, he took it highly amiss. I could scarcely prevail with him to let her go ; and so dreadfully affronted was he that she should have been let go free after all his toil and trouble, that he would not come near me all the way to the house, nor yet taste any supper when we got there. I believe he wanted me to take her home and kill her. He had one very laughable peculiarity, which often created no little disturbance about the house: it was an outrageous ear for music. He never heard music but he drew towards it; and he never 
drew towards it, but he joined in it with all his vigour. It was customary with the worthy old farmer with whom I resided, to perform family worship evening and morning; and before he began, it was always necessary to drive Sirrah to the fields and close the door. If this was at any time forgotten or neglected, the moment that the psalm was raised, he joined with all his zeal, and at such a rate that he drowned the voices of the family before three lines could be sung."

A single shepherd and his dog will accomplish more in gathering a flock of sheep from a Highland farm, than twenty shepherds could do without dogs; and it is a fact that, without this docile animal, the pastoral life would be a mere blank : without the shepherd's dog, the whole of the mountainous land in Scotland would not be worth sixpence. He may be classed with the camel and the reindeer, who, in their respective countries, may be said to be the chief riches and support of the inhabitants.

The multitude of surprising stories, that are well authenticated, of these intelligent animals, would fill volumes, particularly of their attachment to their masters. Rachel has a pretty little spaniel, that, had he the faculty of speech, would have a better title to the appellation of a rational being than some that walk on two legs. He is accustomed to lie and indulge himself on the lawn behind the house; but the 
other morning, as he was going to recline on his favourite spot, he perceived that a heavy dew had wet the grass, and he ventured to the hall, took the mat in his teeth, placed it on the lawn, and then composedly lay down on it.

Such instances of sagacity clearly prove, to my mind, that some animals are endued with a capacity that enables them to observe, and to act from reflection: whether it is called reason or instinct is immaterial; the facts are the same, and are incontrovertible. It is evident that there are gradations of the intellectual powers; and, consequently, that some species of creatures are far more intelligent than others. Dogs seem highly favoured in this respect, and to possess more sense than most of their fellow-brutes; but, as they live on such a very familiar footing with man, I think it probable that they owe part of their superiority to that circumstance. In the qualities of the heart they must be allowed to excel; for what creature is so docile, so faithful, so affectionate, or so generous as the dog? He does not show his attachment merely by following his master and protecting his property, but will sacrifice his own life to defend him when attacked. His powers of discrimination are very great; for the same dog that is gentle, tractable, and playful with the family to which he belongs, becomes, on the approach of a stranger, particu- 
larly if he is shabbily dressed, bold, courageous, and implacable. No bribe can seduce him from the duty he owes to his benefactor. Our favourite poet, Gay, extols his fidelity, in the character of the shepherd, who, with great simplicity, acknowledges that he has learned many moral virtues from those creatures that are called irrational. He says :

"My dog, the trustiest of his kind, With gratitude inflames my mind:

I mark his true, his faithful way,

And in my service copy Tray."

To what innumerable purposes are the capacities of this useful race applied! Their instincts enable them to hunt and catch our game, even in the water. They guard our flocks and herds with amazing dexterity. In our rambles, we have frequent opportunities of observing the qualities of the shepherd's dog. Vast flocks of sheep are fed upon the mountains in this country, and the shepherd receives more assistance from one of these dogs than half a dozen boys could give him. It is really curious to see with what expedition he obeys his master's commands : he watches his eye, and is gone to execute his commission at a word, whether it is to drive the flock with regularity to their pasture, or to conduct them home at night; and, though other flocks are browsing on the same pastures, he prevents any stranger from intermixing 
with those under his care. I have seen a shepherd point out to his dog a straggling sheep on a height more than a mile distant. At the well-known signal, the dog went off at full speed, and soon returned with the runaway to the flock. They acquire this command over the sheep merely by their voice, for they are trained too well to their business to injure their fleecy charge with their teeth.

Dogs that attend drovers have the same qualities. They distinguish accurately the cattle or sheep that belong to the several droves that follow one another; and will neither suffer one of another flock to enter theirs, nor one of those they guard to escape.

I need not point out their use in protecting our houses and property from thieves; but one of their valuable properties I must mention, before I conclude their eulogium. I mean that of conducting the blind. How many unfortunate wretches, deprived of sight, friendless and poor, are led from door to door, to solicit a small pittance from the hand of charity, by a faithful dog, who conducts them with as much care, and probably more certainty, than one of their own species!

I shall finish this long letter by an instance of sagacity and contrivance, in a terrier belonging to $\mathrm{Mr}$. Palmer, that is really surprising. This dog is extremely attached to the horse that draws his master's chaise; and the moment he sees the servant take out 
the harness, he barks and jumps about for joy. $\mathrm{He}$ had been long permitted to accompany the horse whenever they went abroad; but, having become disagreeably clamorous and troublesome at setting off, $\mathrm{Mr}$. Palmer had given orders that Trim should be beaten and prevented from attending them. The dog was much hurt at this treatment, and, after two or three beatings, disappeared at the moment of setting out, though he had been seen in the yard just before. They are in the very frequent habit of calling at Mrs. Saville's before they proceed to any distance. Trim, determined to avoid the discipline, and yet to enjoy the excursion, came to our cottage, in full expectation that his master would presently follow; but, as he was disappointed, he staid quietly till the next day, and then returned home. A few days after, Mr. Palmer set out for another ride. Trim took a different means to compass his purpose: he left the yard, as before, sooner than the chaise ; but, instead of proceeding to Mrs. Saville's house, he lay at the corner of a lane, which he knew his master must pass to get into the high road. The fidelity of Trim, and the ingenuity of his contrivance, have rendered him a great favourite; and, notwithstanding his noisy joy, he is permitted to attend the chaise, which he never fails to do with marks of the highest satisfaction.

Can you forgive me for troubling you with such 
trifles? - but the uniform tranquillity of our lives does not afford sufficient variety to supply me with anecdotes of a more amusing kind. You must accept my endeavours to please, however deficient I am, and believe me,

With sincere attachment, Ever yours, Caroline. 


\section{LETTER XII.}

FROM EMILY TO CAROLINE.

\section{MY DEAR CAROLINE,}

THE story of your goats proves, beyond doubt, that some animals are capable of reflection; and its probability is confirmed by a similar instance of contrivance in two of the same species, in a different part of the world. At Ardinglass, in Red Bay, near Glenarm, in Ireland, two goats happened to be moving towards each other, over a deadful precipice, on a path so narrow that it was impossible for them to pass each other, and still less practicable for either to turn round: the least attempt to effect the one or the other of these movements would have precipitated them from the rock, which is there four hundred feet perpendicular. In this dilemma, they looked at each other with great seriousness for a length of time, as if they were deliberating how to extricate themselves from the difficulty; which at length they contrived to do, by one of them lying down prostrate, whilst the other walked over his body, each afterwards pursuing his own course with perfect composure.*

* Mr. George Black, brother to the celebrated chemist of Edinburgh, was an eye-witness of this fact. 
The faithful attachment of dogs to their masters has been too often recorded to require confirmation from any new example; yet I cannot deny myself the pleasure of relating an affecting instance of canine friendship, that happened in France during the anarchy of the reign of terror.

A few days before the overthrow of Robespierre, a revolutionary tribunal had condemned Mons. Ran ancient magistrate and a most estimable man, on the pretence that he had been guilty of conspiracy. Mons. R — had a spaniel, at that time about twelve years old, which had been brought up by him, and had scarcely ever quitted his side. He was thrown into prison. His faithful dog was with him when he was seized, but was not suffered to accompany him into confinement. The dog took refuge with a neighbour of his master's, and every day, at the same hour, returned to the door of the prison. Such unwearied fidelity at length excited the compassion even of the porter, and the dog was allowed to enter. The joy of the master and his dog was mutual. It was found difficult again to separate them; and the gaoler, fearful (if the dog should be discovered there) that his governors might consider him as favouring a prisoner, was compelled to carry him out. The animal returned regularly every evening, and was as regularly admitted. On the day appointed for receiving sentence, 
the dog, in spite of the guards, penetrated into the hall, and crouched between his master's legs. At the execution he was also present, and was with difficulty forced from the body. For two nights and a day he remained on the grave. The friend of his master, who had before afforded him an asylum, unhappy at not seeing the dog as usual, and guessing to what place he had retired, stole forth by night, and finding him at the grave, caressed and brought him back. He tried every means that kindness could devise to induce him to eat; but in a short time the dog escaped, and regained his favourite place. For three months he came every morning to his protector, merely to receive his food, and immediately returned to the grave. At the end of this time nature gave way: he languished, refused to take any nourishment, and died. What friendship could have been more pure, more.constant, or more fervent? The hour of adversity did not dismay him; and though he could not fully comprehend the injuries offered to his master, he suspected that some harm was intended, and guarded him, as far as was possible, with the greatest vigilance. How deep, how lasting were his regrets! His attachment deserved a monument that should have perpetuated the memory of his master with the fidelity of the dog, bearing this inscription:

"I loved thee even unto death." 
It seems very extraordinary that such an affection should subsist between creatures so different in their natures, their powers, and their inclinations; between whom, one should suppose, there could be no sympathy or communication of ideas; did we not daily see instances of this strong, marked attachment of the canine race to their masters, and, in different degrees, to every member of his family. May we not attribute this valuable property of the dog to the goodness of the Great Creator, who has so amply provided for the wants of man in every situation? How many have been saved from drowning, from thieves, and from other dangers, by the sagacity of their dogs ! Some time ago I read a paragraph in the newspaper, of the preservation of a man by the means of his dog; and although the names of the persons have escaped my memory, yet the circumstances were related in such an authentic manner, that $I$ shall venture to repeat them.

A gentleman's servant, in the neighbourhood of Windsor, went out with two horses and a dog, for the sake of exercise. After some hours, the horses came home without either the man or the dog. This caused great alarm to the family: other servants were despatched different ways in quest of the poor fellow, who was supposed to have met with some unfortunate accident. After a very tedious search, the dog 
was seen standing in the midst of a turnip-field, with evident marks of distress and uneasiness. On seeing the servants approach, he advanced, and, by every possible sign, indicated his anxiety for them to follow. He led them in this manner into a lane, where, as they saw nothing, they attempted to return; but the dog's importunity was so great, that they determined to follow wherever he should lead. He conducted them to the side of a ditch, in which they found the groom in a state of insensibility, having received a fracture of the skull by a fall from the horse. A proper vehicle was procured, and the unfortunate man was conveyed to his master's house, and placed in a comfortable bed. A surgeon was sent for, and the wound was dressed. During this operation, it was impossible to keep the dog out of the chamber. As soon as all was quiet, this faithful creature placed himself upon the bed; and though the poor sufferer, in the violence of his delirium, often struck the dog, the animal seemed to understand that he was not in his right senses, for neither blows, nor the repulsive voice of his agonised master, could drive him from the post he had chosen. The man recovered, and, no doubt, ever after valued this affectionate creature, to whose attachment he owed his life.

Of all the different kinds of dogs, the Newfoundland seems to possess the most sense, and the strongest 
attachment. An extraordinary instance of both, Bewick, in his History of Quadrupeds, relates in the following words: "During a severe storm, in the winter of the year 1789, a ship belonging to Newcastle was lost near Yarmouth, and a Newfoundland dog alone escaped to shore, bringing in his mouth the captain's pocket-book. He landed amidst a number of people, several of whom in vain endeavoured to take it from him. The sagacious animal, as if sensible of the importance of the charge, which, in all probability, was delivered to him by his perishing master, at length leaped fawningly against the breast of a man who had attracted his notice among the crowd, and delivered the book to him. The dog immediately returned to the place where he had landed, and watched with great attention for every thing that came from the wrecked vessel, seizing hold of them, and endeavouring to bring them to land."

I dare say you know that the habits of this breed of dogs lead them to swim and dive; and it is most likely that in a state of nature their food is fish, for they are known to devour raw trout and other small fish. Providence has accordingly furnished them with web-feet, which serve them for paddles, and are not bestowed on any kind of $\operatorname{dog}$ but those that frequent the water. How exactly the habits and form of all creatures correspond with one another! Had you 
not led my attention to the Book of Nature, I should have overlooked this, and many other beautiful proofs of design in the creation of the inhabitants of the world.

Farewell, my Caroline: continue to instruct with your amusing correspondence

Your affectionate

EMILY. 


\section{LETTER XIII.}

FROM CAROLINE TO EMILY.

\section{DEAR EMILY,}

"Blest be the gracious power who taught mankind To stamp a lasting image of the mind !

Beasts may convey, and tuneful birds may sing, Their mutual feelings in the opening spring;

But man alone has skill and power to send The heart's warm dictates to the distant friend:

'Tis his alone to please, instruct, advise, Ages remote, and nations yet to rise."

IN these sentiments of gratitude for the invention of letters, I cordially unite with Mr. Crabbe, the author of the lines I have borrowed for the expression of my own feelings upon the subject. What, indeed, would have been my distress, on my first retirement into Wales, if all intercourse with you, my dear Emily, had been impossible! But, by means of this delightful invention, wherever a post can reach, an exchange of sentiments may be enjoyed:- our joys, our sorrows, may be communicated to the friend of 
our hearts, though separated by hundreds of miles. Through this medium, you are become acquainted with my revered Mrs. Saville, and my beloved Rachel. You know their characters, you admire their excellences, and love them for their kindness to me, a stranger, under circumstances that too often deprive us of the regard of old acquaintance, who are more attached to our fortunes and rank in society than to ourselves. The friendship of my good aunt and cousin is generally founded on esteem : towards me, at first, it was compassion, and that ardent desire of doing good, that is the principal spring of Mrs. Saville's actions. By this time, I am vain enough to believe, that I have gained a higher place in their regard, by my sincere endeavours to conform to their inclinations, and, at a humble distance, to imitate their virtues. Cheerfulness is cultivated here as a duty: every thing that is morose, austere, and gloomy, is banished from this happy cottage. One of Mrs. Saville's first maxims is, to be contented with that lot which Divine Wisdom has chosen for us, and to silence all murmurings and regrets for the privation of those things that others possess, by remembering how much we enjoy that which multitudes have not. Gratitude, she thinks, is the most acceptable part of devotion ; and she is almost angry if she hears any one complain 
of small inconveniences. She often tells us, that the secret of being happy is, to be satisfied with the present, and to leave the disposal of the future with full confidence to the Supreme Ruler of the universe: for orer anxiety destroys the health, and incapacitates us for duties that require our immediate attention. Every day opens to her a new scene of activity and usefulness : of course, she is never teased with that languor of mind well known amongst fashionable loungers by the name of ennui. Her time is divided between acts of benevolence, the cultivation of her mind, and social pleasures. She has found a few select friends, even in this retired situation, that vary and enliven our enjoyments: amongst these, the Palmers are our greatest intimates. We seldom pass a week without spending an evening together; not in the formal style of visiting, but in that familiar way that gives full scope to conversation. At our last meeting, part of your letter was read aloud; and I am desired to return our general thanks for the amusement it afforded us. Every one of us was affected by the story of Mons. $\mathrm{R}$ — , to whom the friendship of a dog must have been a consolation when all the world had abandoned him. "He must have been a very faithful creature indeed," said Laura Palmer, a most engaging little girl of ten years old, "and I should have 
grieved when he died. Papa, if you will give me leave, I will repeat a sweet story of a dog, that I read this morning, in the book you lent me." Mr. Palmer nodded approbation; and Laura, with great diffidence, gave us the following account:- " In digging up the ruins of Pompeii and Herculaneum, which were overwhelmed by the lava thrown up in an eruption of Mount Vesuvius, the skeleton of a dog was found, stretched over that of a child ten or twelve years of age. It was conjectured, by those who superintended the workmen, that this dog, from his position, was attempting to save his young master at the moment of the dreadful catastrophe that destroyed the city. This opinion was confirmed by the discovery of a collar of curious workmanship, that is preserved in the gallery of the Grand Duke of Tuscany, upon which was inscribed a history of this dog, in Greek. From the inscription, it appears that this dog, whose name was Delta, belonged to a man called Severinus, whose life he had saved on three different occasions: first, by dragging him out of the sea, when nearly drowned; again, by driving off four robbers who attacked him unawares; and, the third time, by destroying a she-wolf, which was near tearing Severinus in pieces, on account of his having taken her cubs from her, in a grove sacred to Diana, near Herculaneum. After these exploits, 
Delta attached himself particularly to the only son of Severinus, followed him wherever he went, and would take no food but what he received from the hand of this child. The circumstances and the inscription place the existence of the dog out of all doubt; amounting to a proof that the faithful animal would not forsake his young master, and, when he found it impossible to save him, like a servant of unshaken fidelity, shared his fate."

"After all these fine stories of the generous nature of dogs," said Mrs. Palmer, "the inferiority of the cat must be allowed; as her general character is artful, revengeful, cruel, rapacious, and ungrateful. Nature has endowed her with the qualities of a beast of prey, being formed to live upon animals weaker and more defenceless than herself. Yet, when domesticated, there have been some instances of sagacity and attachment in this creature, that may serve to diminish the stigma that is cast upon the species. Our countryman Mr. Pennant tells us, that a very remarkable incident befel Henry Wriothesly, Earl of Southampton, the friend and companion of the Earl of Essex in his fatal insurrection. After he had been confined in the Tower a short time, he was agreeably surprised by a visit from his favourite cat, which, according to tradition, having found her way thither, descended the chimney of 
his apartment, and seated herself by her master. $\mathrm{He}$ adds, that a picture, in the possession of the Duchess of Portland at Bulstrode, of this nobleman, in a black dress and cloak, with the faithful animal at his side, may be supposed either to confirm the fact, or to have given rise to such an extraordinary story.

"A circumstance happened in my own neighbourhood, a few years ago," continued Mrs. Palmer, " the truth of which I cannot doubt, as it was related to me by a person who was a spectator of the occurrence." The mistress of the house was sitting by the fire, when the cat came to her, and, looking up in her face, mewed most piteously. At first, being engaged, she paid no attention to it; but the cat was not to be discouraged by this neglect: she continued her cries, going towards the door, and returning to the lady, in the greatest agitation. These actions were so often repeated, and in such an impressive manner, that she felt curious to know the cause of such uneasiness; though she was reluctant to leave her seat, till the cat, extending her claws, pulled her by the apron. She could no longer resist the importunity of the distressed animal: she rose, and followed her conductor into a small wash-house, where some tubs, partly filled with water, were standing, into one of which a child nearly two years

* On the authority of Mrs. Cobbold of Ipswich. 
old, had fallen, and was in danger of drowning. This intelligent cat saved the child's life, and in this instance showed a degree of attachment superior to that commonly observed in her kind. Yet, on the removal of the family, some time afterwards, she could not be retained in their new habitation, but, in spite of every precaution, returned to their former abode."

"The attachment of cats to houses rather than persons," replied Mrs. Saville, " is supposed to arise from their perfect knowledge of the outlets and passages of the place where they have lived, as well as the holes in which the rats and mice have fixed their retreats. Now it is possible that the aversion they show to a change of situation may originate from a fear of want of food, from not knowing, where to seek for their prey."

Thus our meetings pass in the most agreeable and profitable manner, instruction being mixed with our conversation; and it seldom happens that we part without hearing some curious anecdotes, either relative to history, the characters of great men, the wonders of nature, or some other interesting subject. And when any thing is more extraordinary than usual, I insert it in a common-place book that I keep for the purpose. Looking over this book in the 
morning, I was struck with the following article, which I thought worth your perusal. Mr. Parkinson, in his Organic Remains, makes a calculation of the number of pieces he found in a species of animal fossil, of the family of encrinites, that is truly astonishing. "A careful examination," says he, "ascertains the curious fact that, independently of the number of pieces which may be contained in the vertebral column, and which, from its probable great length, may be very numerous, the fossil skeleton of the superior part of this animal consists of at least twenty-six thousand pieces." They are disposed in the following manner:

Of the bones forming the body, there are five central • . . . 5

Five ribs . . . . . 5

Five clavicles $\quad$. $\quad$. 5

Five scapulæ $\quad$. $\quad . \quad \ldots \quad 5$

Arms.- Six bones in each of the ten arms . . . .

HANDS.-Each hand being formed of two fingers, and each finger consisting of at least forty small bones, these, in twenty fingers, make • . . . . 800

Tentacula : thirty proceeding from each of the six bones, in each of the ten arms, make a d 1,800

Carried forward $\quad 2,680$ 


Brought forward
Thirty proceeding, on the average,
from each of the eight hundred
bones of the fingers, make
Total

What wonderful art and mechanism does this creature display! And though so complex in its construction, yet, when alive, every limb, every joint, and every bone, performed its part without disorder, or in any way interfering with each other: affording complete enjoyment to the creature, and enabling it to move in every direction which the functions of its nature required.

The globe we inhabit abounds with objects both curious and surprising; yet multitudes of people, and those of the better sort, live fifty or sixty years upon it without making the faintest attempt to become acquainted with them. Does this proceed from a want of taste, or a neglect in forming the mind early to observation? I rather think the latter; for surely none can see the beauties of creation and not admire them. Children brought up in crowded cities are to be pitied in this respect: they see scarcely any thing but the works of art, and they associate the ideas of beauty and value to the productions of the mechanic only. An insect is often an object of abhorrence to 
GOD'S WORKS FULL OF WISDOM.

them, when, if they would examine it in its true point of view, it would teach this important lesson: That the most insignificant of the Creator's works are full of wisdom and goodness.

Mrs. Saville is preparing for a walk; Rachel is at my elbow, with my bonnet in her hand: so adieu, adieu, says your affectionate

Caroline. 


\section{LETTER XIV.}

FROM EMILY TO CAROLINE.

\section{DEAR CAROLINE,}

So far from pitying you for your banishment from London, and from all the luxuries of genteel life, I am inclined to envy the delights you enjoy in your snug cottage; where you seem to possess all the solid comforts you can desire, with many intellectual pleasures that are seldom to be found amongst those who are continually on the search for something new to banish reflection and kill time. The society of Mrs. Saville and the amiable Rachel alone is a compensation for that of half your town acquaintance, whose highest subject of investigation is the most becoming dishabille, or the most dazzling full dress. The Misses Ormond weary me with this topic: every time they have a fresh supply from their milliner or dress-maker, their coach is ordered, for the friendly purpose of exhibiting the latest fashions to my admiring eyes. But your example has checked my ardour for being the first in the mode, or giving in to every folly that is authorised by the multitude. My ap- 
plause, therefore, diminishes in value, and they already laugh at me, as being quite Gothic, because I will not become a slave to fashion. Our correspondence is also a subject of ridicule for them: they say we write about nothing but cats, dogs, and magpies, and that our letters could only amuse a man who shows wild beasts at a fair. They have no eyes for the beauties of nature, or the wonders displayed in the dispositions of the various tribes of animals. The only individual they notice, of the inferior orders of creation, is a delicate French lap-dog, which they carry in their arms, and on which they bestow as much tenderness and attention as would bring up a child. This dog is washed and combed regularly, and fed upon the most delicate food, whilst the petition of an officer's widow, with four children in a starving condition, was refused because they had nothing to spare; when, only a few days before, they had purchased this useless creature for five guineas. But they are so wholly occupied with themselves, with their rank and consequence, and the gratification of their vanity, that they have no place in their hearts for the pleasures of sympathy with the unfortunate, or the exquisite gratification of relieving their distress. They have a great desire to be accomplished, especially in music, because it is fashionable; but, except for that, they have neither taste nor application. And as for 
the cultivation of their understandings by a course of reading, it is forbidden by want of leisure and inclination. Their reading seldom extends beyond a popular novel. They openly avow that they do not think it necessary in order to make a figure in company, and therefore it is a useless labour; "For," says Charlotte, "if a young lady can dress, dance, and play, there is no opportunity of inquiring whether she knows a great deal. Besides, the men do not choose learned wives, lest they should have more knowledge than themselves." An elderly lady, who was sitting by when she made this remark, said, that men of sense were not afraid of women whose minds were enriched with the productions of the best authors; but they very properly avoided the pedantic display of smatterers in learning, who assumed, upon very partial acquirements, a superiority to which they had no pretensions:- - that she who outstepped the limits of that modesty which is the chief ornament of the sex, whether in exhibiting her knowledge, or in the freedom of her manners, rendered herself equally an object of disgust and ridicule:- that it was not ignorance, but humility, that was valued in young women; and that, whilst they kept their proper places, there was no danger of a well-furnished mind exciting the jealousy of the other sex.

I was sorry her observations were interrupted by 
the arrival of a cousin of Lord Ormond's, who is lately returned from the East Indies. He brought with him many curiosities, as presents for the young ladies. After the shawls, chintz, and taffeties had been opened and sufficiently admired, several birds and a monkey were introduced. The latter, his lordship did not choose to accept; because, he said, he still bore the scar of a bite, given him, fifty years ago, by one of the tribe in a fit of revenge, "The animal," continued he, "was of that species called montego: he was kept by a farmer, at a few miles' distance from the village where I went to school. It was a holiday; and a party of us directed our walk to the farm, in order to amuse ourselves with the tricks and grimaces of this monkey, which, being the only one in that part of the country, was regarded as a great rarity, and often visited by the boys of our school. It was fortunate for me that he was confined by a strong chain to the shed which was built for his habitation, or he might have attacked my throat, and done me a more serious injury. All my companions had furnished their pockets with nuts, apples, and gingerbread, which they had provided for his refreshment; a precaution that I alone had forgotten. Being very unwilling to approach Jacquot with an empty hand, I offered him a cockle-shell that I had picked up on the sea-shore: he seized 
it greedily, and presently opening it with great adroitness, was much incensed to find nothing in the inside of it, perhaps supposing that I had imposed upon him. He instantly expressed his resentment by throwing it away with great indignation, and, by his whole behaviour, showing his contempt for the trick he thought I had put upon him. My companions continued playing with him for more than half an hour, whilst I and another amused ourselves about the farm-yard. At last we were summoned to prepare for our return, when each of us took leave of the monkey by shaking his fore paw : a civility he received very cordially till it came to my turn, when, recollecting the offence I had given him, he flew at me with the utmost rage, and left this mark in my hand, which I shall carry to my grave. Therefore, no monkeys, if you please, young ladies," said the old gentleman in an angry tone.

The girls looked vexed, but did not dare to reply; for though they have a great ascendency over him by wheedling and coaxing, like other weak men, he is violent when opposed.

The conversation took a general turn, and I was well entertained by many of the observations of the traveller, who has been long abroad: and perceiving that my attention was fixed upon the animals, and that I was desirous of knowing their habits and in- 
stincts, he very politely indulged my curiosity with several particulars that he had seen in different parts of Asia. But nothing delighted me so much as the extraordinary contrivance of a certain species of sparrow, found in Hindostan, which, in the night-time, lights up her nest with glow-worms; and, after collecting them for this purpose, she fastens them to the inside of her nest, by means of a peculiar kind of clay, of a glutinous nature. What an elegant illumination, could our minds be divested of the sufferings of the poor glow-worms, whose brilliancy subjects them to a painful death! They form an apt emblem of beauty, that so often misleads its possessor into error and folly.

The subject is less pleasing, but the conduct of the creatures that are exposed to each other's fury, in the combats of wild beasts, in the island of Java, at which this gentleman was present, marks their instincts for self-defence in a very strong point of view.†

When a tiger and a buffalo are to fight for the amusement of the court, they are both brought upon the field of combat in large cages. The place is surrounded by a body of Javanese, four deep, with levelled pikes, in order that, if the creatures endea-

* Asiatic Annual Register, 1802.

† Stavorinus' Voyages to the East Indies. 
vour to break through, they may be killed immediately. This, however, is not so easily effected, but that many of these poor wretches are torn in pieces or dreadfully wounded by the enraged animals.

When every thing is in readiness, the cage of the buffalo is first opened at the top, and his back is rubbed with the leaves of a certain plant, which have the singular quality of occasioning intolerable pain. The door of the cage is then set open, and the animal leaps out, raging with agony, and roaring most dreadfully. The cage of the tiger is then likewise opened, and fire is thrown into it, to make the beast quit it; which he generally does, running backwards out of it. The tiger no sooner perceives the buffalo, than he springs upon him: his huge opponent stands expecting him, with his horns upon the ground, in order to catch him upon them, and throw him in the air. If the buffalo succeeds in his design, and the tiger recovers from his fall, he generally loses every wish of renewing the combat; and if the tiger avoids this first attempt of the buffalo, he springs upon him, and seizing him in the neck, or other parts, tears his flesh from his bones. In most cases, however, the strength of the buffalo overcomes the address and ferocity of the tiger.

This gentleman has promised to pass a few weeks at Belvoir Castle, which will probably afford me op- 
portunities of collecting more anecdotes on our favourite topic, as he appears to be a minute observer of the wonders of nature.

My letter is extended to so great a length, I can only add, that I am, with sincere attachment,

Yours,

EmiLy. 


\section{LETTER XV.}

FROM CAROLINE TO EMILY.

\section{MY DEAR EMILY,}

Revenge is not confined to the monkey tribe: other animals are very susceptible of this odious passion; and as they are deficient in that reason which is given to us to restrain our evil propensities, they yield to the impulse of their feelings, without an attempt to subdue them. Sonnini, who visited Egypt, tells us that the camel, so distinguished for its patience and forbearance, is yet sensibly affected by injustice or ill-treatment. " "The Arabs," says he, "assert, that if a person has struck one without cause, he will not find it easy to escape its vengeance; and that they will retain the remembrance of it, till an opportunity offers of gratifying their revenge. It is said, that in their fits of rage, they sometimes take up a man with their teeth, throw him on the ground, and trample him under their feet. Eager to revenge themselves, they no longer retain any rancour when once they are satisfied; and it is even sufficient, if they believe they have satiated their vengeance. Accordingly, when an Arab has excited the rage of a camel, he 
lays down his garments in some place near which the animal will pass, and disposes them in such a manner that they appear to cover a man sleeping under them. The camel knows the clothes of him by whom he has been treated with injustice, seizes them in his teeth, shakes them with violence, and tramples on them in a rage. When his anger is appeased, he leaves them; and then the owner of the dress may make his appearance without fear, load and guide the animal, who submits, with amazing docility, to the will of a man whom, just before, he wished to destroy.

"I have sometimes seen," says he, " dromedaries, weary of the impatience of their riders, stop short, turn round their long necks to bite them, and utter cries of rage. In these circumstances, the rider must be careful not to alight, as he would infallibly be torn to pieces; he must also refrain from striking his beast, which would only increase his fury. Nothing can be done but to have patience, and appease the animal by patting him with the hand, which frequently requires some time, when he will resume his way and his pace of himself."

To those who view the animal kingdom with an attentive eye, the correspondence of the structure of the different creatures, as well as the peculiar senses bestowed upon each, with their wants and the climates 
they inhabit, are no less convincing proofs than their instincts, of the Infinite Intelligence that has adapted them exactly to that place which they are appointed to fill in the ranks of creation. The camel is to the Arab, what the rein-deer is to the Laplander: it is his all-his treasure. These creatures supply food and clothing to their possessors, besides their wonderful powers of conveying their masters with great rapidity to a vast distance. The camel is formed to traverse extensive deserts of sand, where the thirsty traveller often perishes from want of water: it is accordingly provided with a peculiar resource against the calamity to which it is so frequently exposed. Besides the four stomachs which it has in common with other ruminating animals, it has a fifth bag, in which water is preserved without spoiling or mixing with the other aliments. When the camel is on a journey, and wants water to soften its food whilst ruminating, it has only to contract this bag by means of certain muscles, and as much water as is required passes into its stomach. In consequence of this peculiar formation, this valuable creature can take a prodigious quantity of water at one draught, and can sustain life for several days without drinking. They are, moreover, endowed with the extraordinary property of discovering water by their smell at half a league's distance; and, after being some time deprived of it, will 
hasten towards the spring, long before their riders perceive that any is at hand.

We have already seen that the goat is furnished with a hollow foot, to prevent it from slipping off the precipices: the broad foot of the camel is equally well adapted for treading on a sandy level; nor can it make a firm step on moist or slippery ground, or climb with safety a steep ascent or a shelving declivity. Had the camel and the goat, (the one an inhabitant of the plain, the other of the mountains, ) each remaining in other respects the same, exchanged feet, neither could have subsisted in their native climes. The properties of the rein-deer are as opposite to those of the camel, as the frozen regions he inhabits are to the scorching deserts of Arabia. He can endure the utmost extreme of cold, and his hunger is satisfied with a little moss, that his instincts teach him to seek with his hoofs under the snow.

Can any one observe this harmony of nature, and not acknowledge the Divine Hand that has so nicely adapted the creature and its natural situation to each other? The whole earth teems with such correspondencies, had I but knowledge and leisure to display them. The rational mind cannot doubt that the innumerable worlds that are dispersed in infinite space abound likewise in monuments of the same wisdom and goodness. 
An instance of this conformity of the structure of animals with the mode of life appointed for them occurred to us last night, as we were drinking tea at Mr. Palmer's. A boy having discovered the haunt of a viper near the garden hedge, $\mathrm{Mr}$. Palmer hastened to the spot, destroyed the dangerous intruder, and afterwards brought it into the parlour, in order to show us the curious formation of the jaws and gullet, so admirably adapted for swallowing food much thicker than the usual size of the creature's body. In order to accomplish this purpose, the head of this creature is broad and flat, having a wide mouth, of very uncommon and disproportionate size, which allows the jaws to gape to a great extent. But this opening, capacious as it is, would not be capable of receiving the viper's prey, had not its capacity of enlargement been still further increased by the following nice contrivance. The jaws are not united together at the bottom, as in the human mouth, by a sort of joint resembling a pair of hinges, but connected by a strong muscle, which is so elastic as to keep the features firm when not in action, and to allow their being stretched to an immoderate extent when the size or form of the prey seized by the viper requires it. The gullet, or throat, receives the food from the mouth, and being very large and elastic, easily enlarges or contracts, according to the size and shape of the substance to be swallowed. From hence a part only is at once received into the 
stomach, which is by no means so large a receptacle as the gullet: here it continues till the usual course of digestion reduces it to chyle, which, going off in the natural way, affords room for the remaining part to enter the stomach, and digest in like manner as the former.

The examination of this viper turned the conversation on the subject of serpents in general, and particularly on the strange power that has often been attributed to them, of fascinating their prey to that degree, that, notwithstanding the dread that every creature feels at the sight of their natural enemies, the prey of the serpent tribe are said to approach their destroyers, and even to go, by an irresistible impulse, into their mouths. Some naturalists dispute the existence of this power in the serpent, and imagine that fear occasions this self-devotion of its prey; whilst others suppose that the maternal affection of birds induces the old one to present herself to the ravager, with design to withdraw his attention from her young, and, in her anxiety for their safety, to venture incautiously so far that she can no longer recede from the grasp of her enemy. That this is not always the case, is proved by an experiment mentioned in the Philosophical Transactions. "A viper-catcher, who had more than sixty living vipers in a chest, put a living mouse in among them. Now, it is well known that these creatures never feed whilst in confinement, unless it be a 
fernale that is with young. One of the vipers in the chest happened to be in this situation. None of the others paid any attention to the mouse; but she raised up her head a little, and looked furiously at it. The terrified mouse stood still for a considerable time; though the viper continued rolled up in a spiral form, only raising up her head and looking at it, vibrating her tongue at the same time. The mouse at length took courage to move, but without running away, only walking, as if terrified, round and round the viper, squeaking frequently as it went; till at length it came before the head of its enemy, which was still in an erect posture, with the mouth open. The unfortunate mouse, after some time, drew nearer, and at last crept into the viper's mouth, where it was gradually swallowed, without obliging her to alter her position."

Tasso has given a beautiful description of one of this wily race, in his Jerusalem Delivered, which to you, who have a poetical taste, cannot fail of being an acceptable sequel to the subject.

"When lo! a serpent rushing from his cell, Opposed their passage, horrible and fell! Aloft his head and squalid breast he held; Bestreak'd with gold, his neck with anger swell'd; Fire fill'd his eyes; he hid the path beneath; And smoke and poison issued with his breath. Now in thick curls, his scaly length he wound; Now trail'd his opening curls along the ground." 
I will now dismiss the inferior orders of creation, and fill the remainder of my sheet with some anecdotes that will make you better acquainted with Mr. Palmer's character. When he was first presented to the living he now enjoys, ignorance and vice prevailed to a lamentable extent amongst his parishioners. His first care was to make himself beloved by the exercise of every kind office, and to alleviate, as much as possible, their temporal wants. Having gained their affections, he began to give them advice as a friend; and by the slow but powerful influence of example, united with precept, enlightened and instructed their minds. The interest he took in their affairs, the condescending and sympathetic visits that both he and Mrs. Palmer frequently paid to their neighbours of all classes, endeared them greatly, not to the parish only, but to those who lived beyond its boundaries. General esteem was followed by a degree of respect approaching to veneration. As he is far more desirous of promoting the cause of piety and virtue, than of obtaining the reputation of an orator, his discourses are plain and instructive; enforcing the example of our Divine Master, rather than displaying his learning on abstract subjects that his congregation do not understand: so that the meanest capacity may go home the wiser and better for the lesson delivered from the pulpit. The great aim of his life is, to discharge conscientiously 
the sacred functions of his profession, with the moderation and humility of a Christian, without aspiring after riches or dignity. Nor will you accuse me of drawing a flattering picture, when you know that, through the means of a powerful family connexion, he was, some time ago, presented to a lucrative and dignified benefice; but no offers, however tempting - no persuasions,- - could induce him to leave his flock, to whom he considers himself united for life; and that, having once engaged to devote his time and faculties to their spiritual improvement, he has determined to reject every proposal of temporal advantage, that should dissolve a connexion so dear to him, and that yields so much satisfaction.* With such opinions, you may believe he has no taste for the pleasures of luxury or indulgence: his table is plain, though plentifully supplied. His wife admires his principles, and promotes all his plans. Simplicity, with neatness, appears in every part of her domestic arrangements. The children are brought up to be useful, rather than to shine: the cultivation of their understandings is preferred to showy accomplishments; but great attention is paid to their manners, and the government of the temper. They are but young at present, therefore it is impossible to decide on their future charac-

* A similar anecdote is related of Dr. Burgess, the present bishop of Salisbury. 
ters; but hitherto they are distinguished by their gentleness, activity, and affectionate dispositions.

With this happy family I pass much of my time in a very agreeable manner; perfect intimacy subsisting between them and Mrs. Saville. I am neither dull nor solitary with such associates. My mind is opened to new views; I see things in a different light; and this retirement, which would formerly have been a banishment, is now my choice. My amusements, my employments are new; but they have not less zest than my former ones, and they afford far greater variety than one dull round of visiting and public diversions.

Adieu, my Emily: write soon, and you will give pleasure to your sincerely affectionate

Caroline. 


\section{LETTER XVI.}

FROM EMILY TO CAROLINE.

\section{DEAR CAROLINE,}

WheN my father and Mr. Craven return from the sports of the field, they generally chat over the exploits of the day, and are often led into curious disquisitions on the nature of animals, and other topics of natural history. On these occasions, I am usually an attentive listener, as I employ myself with my work; but seldom take any part in the conversation, unless my curiosity is particularly excited, my father not being fond of interruption. But the other evening I was so much interested, I could not restrain myself from urging Mr. Craven to give me all the information he could on the amazing swiftness of the flight of birds.

A partridge that had escaped beyond the aim of their guns, gave rise to an argument on the comparative velocity of different creatures.

My father remembered having seen a famous racehorse, called Eclipse, gallop a mile in a minute; and he was of opinion that few birds could fly faster. Mr. Craven replied, that the instance he mentioned far exceeded the utmost efforts of horses in general, but that even that extraordinary example would not bear 
any comparison with the ease and swiftness with which the winged tribes cleave the air; especially when the extreme fatigue, lassitude, and debility, that follow such exertions in a horse, are taken into the question. "But," continued he, " in order to give you a more accurate idea of the surprising capacity of birds to pass over a vast space in a short time, I will relate the gradations of motion in different animals, as I heard them from a gentleman who still preserves a taste for the almost-forgotten diversion of hawking, and who has paid particular attention to the present subject. At a Newmarket coursing meeting, the fleetest horse in training was taken out, and a hare being found at a few miles' distance from any cover, the very best brace of greyhounds were let out of slips. It was a dry morning in March, when hares are supposed to be most swift. The greyhounds were never able to turn the hare, which is a proof that her speed was superior to theirs. The jockey who rode the horse was one of the most skilful of his profession, and of a remarkably light weight. His account of the pursuit, in the language of sportsmen, was, that he could live, or keep up with the dogs, but could not draw or get nearer the hare; nay, he acknowledged that she continued to gain upon him.* Rabbits never venture far from their burrows, but it is well known

* Sir John Seabright favoured me with the above information. 
that, for the distance they go, they run much faster than a hare: a fact clearly shown by this circumstance, that few greyhounds ever kill a rabbit in coursing: when they happen to catch them, it is by surprise, or a sudden spring. The slowest flying hawk will strike upon a rabbit with scarcely an appearance of moving; so much more rapidly does it fly, than a rabbit can run. Yet this hawk flies too slowly to catch a partridge: a much swifter species of hawk is requisite for that pursuit, and one of still greater speed for a pigeon; but for a swallow, a hawk must be found that can outstrip all these competitors. Therefore, if we take the speed of the swiftest horse at sixty miles an hour, (though no horse ever maintained that pace for so long a time,) as a standard by which the rest may be estimated, and pursue the calculation from the horse to the greyhound, hare, rabbit, slow hawk, partridge, pigeon, swallow, and hawks of the swiftest kind, we may pretty satisfactorily account for the amazing rapidity with which birds perform long voyages. If we only suppose them to go at the rate of half a mile in a minute for the space of twentyfour hours, they will pass over in that time an extent of more than seven hundred miles; but, if assisted by a favourable current of air, there is reason to suppose that an equal voyage may be performed in less time." 
My father, though astonished at the result, acknowledged that Mr. Craven's reasoning had the greatest air of probability, however incredible it might appear, at the first view, to those who had never made the comparison between the known speed of quadrupeds and the probable swiftness of birds. "How surprising," said I, " that such a little tender creature as a swallow should be capable of enduring such excessive fatigue, and travelling to such vast distances!" This remark drew from Mr. Craven many observations on the harmony of the structure of birds, with their habits and necessities, and the migration of various kinds of animals; which show that he has collected knowledge from books as well as from experience, and pleased me so well that I cannot withhold them from you. "The goodness and wisdom of Providence," said he, " have furnished every creature with those things best adapted to its wants. Birds of passage are admirably qualified for such expeditions as their instincts prompt them to undertake. Let us select the swallow as an example. The narrowness of its front, if the expression be allowable, exposes but a small surface to the resistance of the air. The glossy smoothness of their feathers, which lie so compactly over one another, and, above all, the membraneous cells or cavities distributed in their bones for the reception of air, make them light and buoyant. The length of the outward fea- 
thers of the wings of the swallow tribe qualify them in a peculiar manner for their mode of life, which is being almost always on the wing. Their food is insects, and their forked tail serves as a rudder, to enable them to dart either way in pursuit of their nimble prey, which would otherwise escape them."

At this moment, my cousin Henry, who is a student at Cambridge, but much fonder of the diversions of the turf than the stores of ancient learning, entered the parlour, and confirmed the assertions of Mr. Craven with respect to the progressive swiftness of different kinds of birds, and their capacity for maintaining their speed for a great length of way. He said, that a favourite carrier pigeon won him a considerable sum, by flying from Newmarket to London, a distance of sixty miles within the hour. Since this conversation, I have gone every evening about sun-set to the hill behind the plantations, to watch the rooks returning home from feeding; and I observe that, in the space of a few minutes, I often see them pass a considerable extent; for I can perceive them four or five miles before they reach me, and as far after they have passed me; and the whole, comparatively speaking, the action of a moment. The surprising power of wing bestowed on birds of passage makes me long to know some particulars of their excursions : perhaps your friend $\mathrm{Mr}$. Palmer will satisfy my curiosity. If you can obtain 
any particulars on this subject, it will furnish you with a topic for your reply, which I shall impatiently expect, as nothing affords me more pleasure than to hear from you, and to share in the adventures of your cottage life.

Direct to me in London; for, to my great mortification, my father's affairs oblige him to take up his abode there for a few weeks. I am, my dear Caroline, your affectionate friend,

Emily. 


\section{LETTER XVII.}

FROM CAROLINE TO EMILY.

MY DEAR EMILY,

Your inquiry concerning the passage of birds from one country to another has procured for us a very entertaining lecture from Mr. Palmer on this curious subject, the general sense of which I shall transcribe in my own words. Many species of birds change their situation regularly at particular seasons of the year; either because the food which they live upon fails, or for the sake of a warmer or colder climate, or in search of a more secure retreat for rearing their young. Some cross wide seas, and retire to distant countries; whilst others migrate only from one part of the same country to another part that is more or less warm, according to their constitution. Linnets are said only to shift their quarters, breeding in one part of the island, and removing with their young to another. It appears, that all the individuals of a species do not always make the same journeys, or retreat to the same places. The hooded crow remains in North Britain the whole year, whilst some of the species 
have been known to breed on Dartmoor, in Devonshire. Of those which inhabit Sweden, some remain in certain provinces the whole year; whilst others, in different situations, change their habitations.

It is well known that the cuckoo leaves us in autumn, and does not return till spring: but where he hides himself during the winter, has not yet been discovered.

The wryneck is supposed to feed on ants: when these insects have retired into their winter quarters, hunger obliges him to seek support in a warmer climate.

The fieldfare and the redwing live on berries. Our hedges supply them with this kind of food in winter; and in summer they are feasted in the forests of Norway, and other northern countries.

Larks, fly-catchers, wagtails, and warblers, feed on insects and worms; yet only part of them quit our island on the approach of winter, though it is reasonable to suppose that the same motive would influence them all to act alike.

Every species of curlews, woodcocks, sand-pipers, and plovers, leave this country in the spring, and retire to the North of Europe to breed. As soon as the young can fly, they return here; because the frost, which sets in early in those cold regions, hardens the ground, and deprives them of their natural subsistence, 
which is worms, as their bills can no longer penetrate the earth in search of their prey.

Lapland is a country of lakes, rivers, swamps, and mountains, covered with thick and gloomy forests, that afford, in the summer season, a secure, undisturbed retreat to innumerable multitudes of water-fowl of almost every species, which, in winter, disperse over the greatest part of Europe. Wild swans, geese, ducks, goosanders, divers, and other water-fowl, repair to Lapland to pass the summer, where they rear their young, and are daily regaled on myriads of the larvæ of gnats, and other insects that abound in the lakes of that country. Few of these tribes breed in England. They return from their northern excursion about the beginning of October, and first hover round our shores, till, compelled by severe frosts, they betake themselves to our lakes and rivers. Some of the web-footed are of more hardy constitutions than others, and they are able to endure the ordinary winters of the northern regions; but when the cold is unusually severe, they are obliged to seek a shelter in our more moderate climate.

The gannet visits our shores, in pursuit of the shoals of herrings and pilchards that annually migrate into our seas, and sometimes extends her journeys even to the Tagus, to prey on the sardina. Few of the different species of wild geese and ducks breed 
here: perhaps, because they are too much interrupted in a populous country; for it appears that birds of a shy disposition sometimes leave their usual station for the sake of privacy, when the number of inhabitants increases. Naturalists assert, that when great part of our island was a mere waste-a tract of woods and fens, many species of birds, which now migrate at the breeding season, remained in full confidence throughout the year.

The egret, a species of heron now seldom found in this country, in former times abounded here in great numbers; and the crane, that has totally forsaken us, bred familiarly in our marshes, as, like other clovenfooted water-fowl, (the heron excepted,) they make their nest upon the ground, exposed to the rude touch of every intruder. When the number of people increased, forests were cut down, swamps drained, and the plough made inroads where the ground had never before been turned up: these operations disturbed the solitary haunts of the timid wild-fowl, and by degrees drove them to seek a situation more congenial to their habits; whilst those species that nestle on the almost inaccessible rocks that in some parts impend over the British seas still breed there in vast numbers, having nothing to fear from man, except the rare disturbance of a few desperadoes who venture their lives in search of birds' eggs. 
The migration of animals is a surprising propensity, evidently impressed on them for their preservation by their Creator. Each species knows the proper season for departure, and the course they should pursue. They understand one another, and assemble for their voyage at some appointed signal unknown to us. The time, the place, and the order of their passage, differ according to the species; and what is a still more striking proof of design in these emigrations is, the conformity between the regetation of some plants and the arrival of certain birds of passage. Linnæus observes, that the wood anemone blows in Sweden on the arrival of the swallow, and the marsh marigold when the cuckoo sings. And it is most probable, that it is only from the want of accurate observation that many more such agreements remain unknown; for there may be attractions, or objects of arersion, between plants and animals, that are wholly concealed from us. It is said, that birds of passage follow a leader during the day, who is occasionally changed, and during the night makes a continual cry, that their company may be kept together by the sound.

Swallows that have been hatched too late to acquire their full strength of pinion, or such as are maimed or diseased, have frequently been found in the hollows of rocks on the sea-coasts, and even under water, in a torpid state, from which warmth has revived them. 
From these circumstances doubts have arisen whether swallows migrate or lie dormant; but there are so many proofs of their migration, that there is ground to believe these deviations are only accidental. On the approach of cold weather, they have been often observed hovering on the sea-coast, as if waiting for a calm, or a favourable wind, to waft them to their destined port. In warm climates these tender birds remain stationary, because there is no cold to injure them, or destroy the insects upon which they feed.

Linnæus says, that the female chaffinches alone leave Sweden in September, and migrate to Holland, forsaking their mates till the return of spring; a deviation from the usual course for which it is not easy to account.

This extraordinary propensity to change their residence is not confined to birds; fish and insects are known to migrate at certain seasons. Shoals of herrings, cod, and haddocks, approach our shores at a particular time of the year, and quit them with equal regularity, without leaving a single one behind.

Adanson, a celebrated traveller, relates, that near the river Gambia, in Africa, about eight in the morning in February, there suddenly arose over his head a thick cloud, which darkened the air, and deprived him and his companions of the rays of the sun. He soon found that it was a swarm of locusts, raised about twenty 
or thirty fathoms from the ground, and covering an extent of several leagues. At length, a shower of these insects descended, and, after devouring every green herb whilst they rested, renewed their flight. This cloud was brought by a strong east wind, and was the whole morning in passing over the adjacent country. To the testimony of this traveller may be added, that gnats, bees, and musquitoes, sometimes migrate from one place to another.

Here Mrs. Saville interrupted Mr. Palmer, by remarking that rats migrate from place to place; as, when she was young, she had once an opportunity of observing. Being on a visit with a relation who resided in an old mansion, she slept with a maid-servant at the end of a long gallery in a chamber to which belonged an anti-chamber divided from the bedchamber by folding doors, which were set open on account of a light placed in the middle of the anti-chamber. About midnight they were awakened by a noise, and, on opening the curtains, were much alarmed on seeing a great number of rats surrounding the rushlight. Not knowing how to drive away these unexpected enemies, they threw a pincushion into the midst of them, and in a moment the whole company disappeared. The sudden decampment of the rats frightened the two girls almost as much as their appearance. The servant explained the phenomenon as an 
omen of some misfortune, which, though not satisfactory to Mrs. Saville's more cultivated mind, she was still unable to account for what she had seen, and was almost ready to doubt the evidence of her senses. In this state of suspense she lay watching till morning. When it was time to rise, the maid attempted to reach some of her clothes that had fallen on the ground, when a rat, which had concealed itself in them, flew at her and tore her arm. The next day, carpenters were employed to examine the apartments, but neither crack nor cranny was found through which a rat could pass; it was therefore supposed that these rats were on a journey, and in their passage came down the chimney, and returned by the same aperture."

Mr. Palmer said, that this was an extraordinary instance of the migration of rats, which, in this country, is effected in smaller companies than in the cold regions of the north; where, as travellers relate, the great Norway rats migrate in astonishing multitudes, and never go out of their way, but pass over any obstruction they meet in their road.

Evening closed the conversation. Before we parted, it was proposed that Rachel and I should accompany Mr. and Mrs. Palmer on a little excursion to the sea-coast. We both looked at Mrs. Saville for her

* This circumstance happened in an out-room of the author's, in the house opposite Bow Church in Cheapside. 
approbation, for no pleasure could tempt either of us to do anything disagreeable to her. With a gracious smile she nodded assent, and to-morrow we leave her for a few days. On my return, I shall write again, if your town engagements will leave you leisure to read an epistle from one whose best claim to your notice is her affection.

Caroline. 


\section{LETTER XVIII.}

\section{FROM THE SAME TO THE SAME.}

\section{DEAR EMILY,}

After a very pleasant excursion through the Isle of Anglesey, I am again fixed under the protection of my kind friend Mrs. Saville, who has the valuable art of rendering "to-morrow cheerful as today ;" and, by a happy succession of employment for the body and the mind, teaching her inmates to be contented with themselves, and strangers to ennui. Every one of her family feels the sympathy of friendship for each other. She well knows how to mix the dignity of authority with kindness. Her servants are bound to her, not merely by the sordid ties of interest, but by those of affection: they daily feel her solicitude for their most important concerns, and they reward her care by unfeigned attachment. Old Sarah was as much rejoiced to see us safely returned as Mrs. Saville herself. She lived with my aunt before Rachel was born; and though she treats her with great respect, she is as fond of her as if she were her mother. 
Had you seen our reception, you would have supposed we had been absent a month, instead of a few days.-But I have said enough on this subject: it is time to amuse you with something of a different nature.

In the course of our excursion, we visited the small Island of Priestholm, which lies near the coast of Anglesey. It might be called the land of puffins : fifty acres of ground were literally covered with them; the air, the sea, the rocks, seemed alive with them. They are so tame and inactive as to suffer themselves to be knocked down with a stick. Their legs are placed so far back, that they stand with their heads nearly upright. Their bill forms a triangle, and is of an orange red. The upper part of the plumage, and a collar round the neck, are blackish, softened into a greyish white; and the under parts are quite white. The legs are orange. Their tail and wings are short. They do not rise from the ground with facility; which makes them generally careful to alight on places from whence they can either run down the slope of a hill, or throw themselves from the rocks.

Puffins are birds of passage, and resort to these coasts in the spring, remaining here till about the 11 th of August. They are formidable enemies to the rabbits, that were once numerous on this island; for, on their arrival, they immediately take possession of 
the burrows in the crevices of the rocks, or on the sloping ground; and if the latest comers find all the holes occupied, they make new ones for themselves. We were told that the male birds undertake this task; and that, while they are thus employed, they are so intent on their work, that they are easily caught with the hand. These invaders have nearly extirpated the rabbits; for few of these defenceless animals are able to resist the strength of their beaks.

They form something like a nest, of a few sticks and some grass put together, on which the female lays a single white egg, that is generally hatched in the beginning of July. The parent birds are thought to sit alternately, and each by turns goes abroad for food. They are easily taken whilst sitting or rearing their young; and if set at liberty, these silly birds, instead of flying away, either from parental fondness, or for the sake of shelter, hurry back to their young brood, and fall into the hands of their enemies.

Young puffins are pickled for sale, and form an article of traffic peculiar to this neighbourhood; but they are apt to have a strong flavour, from feeding on sprats and sea-weeds.

As we have lately turned our attention to the subject of migration, perhaps you will be entertained with some account of the land-crab, that is found in the Bahama Islands, as well as in most tropical countries, 
and feeds upon regetables. These animals not only live in a kind of orderly society in their retreats in the mountains, but march regularly about April or May to the sea-side, in a body of some millions at a time. At the proper season, they sally out from the stumps of hollow trees, the clefts of rocks, and the holes which they dig for themselves under the surface of the earth. When they are on their march, the ground is covered with them, so that a step can scarcely be taken without treading on them. The sea is their place of destination, and to that they advance without any deviation. No geometrician could send them to their appointed station by a shorter course: they neither turn to the right nor to the left, whatever obstacle intervenes; even if a house stand in the way, they will attempt to scale the walls. Natural impediments are not so easily overcome; they are obliged to conform to the face of the country: if it is intersected with rivers, they are then seen to wind along the course of the stream. The procession from the mourtains is generally formed into three divisions. The first consists of the strongest and boldest males, that, like pioneers, clear the way, and face the greatest dangers. These are often obliged to halt for want of rain, and seek the most convenient retirement, till a change of weather enables them to go forward. The main body is composed of females, which never 
leave the mountains till the rainy season is begun. They march in regular order, being formed into columns fifty paces broad and three miles long, and so close that they almost cover the ground. In a few days this company is followed by a parcel of stragglers, male and female, that are not so strong as those which have advanced before them. They travel chiefly in the night; but if a shower falls in the day, they do not fail to take advantage of it. If they are alarmed, they turn back in a confused, disorderly manner, holding up their nippers and clattering them together, as a sort of threat to their enemies. When any one of them happens to be wounded or maimed, so that he cannot proceed, they devour him without mercy, as if determined to get rid of all impediments, and then pursue their march.

As soon as their journey, which lasts several weeks, is concluded by reaching the shore, they prepare to cast their spawn, by suffering the waves to wash over their bodies; which is supposed to assist the growth of the eggs, for they soon afterwards appear under the barbs of the tail in a bunch as large as a hen's egg. They now seek the shore for the last time, and deposit their spawn in the water, leaving it to the chance of accidents to preserve or destroy them. At this season, when it is said that the waters are blackened by the crabs' spawn, shoals of hungry fish ap- 
proach the shore, in expectation of this annual supply of food, and countless millions of these eggs are devoured by their rapacious enemies. Those that escape the general destruction are hatched under the sand; and soon after multitudes of these young crabs are seen travelling towards the mountains. The old ones, by this time, are grown so lean and feeble, that they are obliged to remain in the flat parts of the country till they are more able to return: in this state they retreat into holes, closing the entrance with leaves and dirt, that they may be secured from the air whilst they throw off their shells and gain new ones. During this operation, they are quite naked, and almost motionless. As soon as the new shell is sufficiently hardened, the crab sets out on its return, and having recovered its flesh, is at that time very good eating.*

It has been asserted, that when crabs have lost their shells, the place of their retreat is frequently guarded by a hard-shelled crab, who, at that time, advances boldly to meet the foe, and will with difficulty quit the field; yet shows great timidity on other occasions, and has a wonderful speed in attempting his escape; but, if often interrupted, feigns death in order to deceive his pursuer, whilst he watches an opportunity to sink himself into the

* Encyclopædia Britannica. 
sand, leaving only his eyes exposed. Whether this account refers to any particular species of crab, or to the whole kind, I am not able to ascertain.

I cannot conclude without relating a very singular circumstance that has happened at the parsonagehouse, and given Mr. Palmer much uneasiness.* I must begin my story by telling you, that a large house-dog is kept in the yard, who is a sagacious animal ; kind to his friends, but formidable to those whom he regards as the enemies of the family. This $\operatorname{dog}$ is let loose of a night. A labourer, who has been employed on the farm long enough to gain some confidence, was entrusted with the key of the barn, and frequently employed to bring sacks of corn from the barn to the house for family use. One night this man went, after the dog, who knew him well, was unchained, and took a sack of corn. The dog attended him very quietly as long as he pursued the path that led to his master's house; but when he turned his course into the road that led him to the village, he caught hold of his coat and would not let him stir; as much as to say, "Where are you going with my master's corn?" The man tried then to go

* This singular instance of sagacity happened at Church Eden in Staffordshire, and is related on the authority of the late Mr. Sneyd, of Belmont. 
back again with the sack to the barm; but the dog, as if conscious of his design, would neither let him do that, nor yet carry the sack to the parsonage. In this dilemma the man was obliged to remain all night, standing with the sack of corn and the dog, who held him fast, though he did not bite or hurt him in the least; and in this strange situation he was found in the morning. A circumstance so extraordinary led to a discovery of his guilty intention; for he could not account how he came there with a sack of corn, pinned down by the dog, but by throwing himself on Mr. Palmer's mercy, and making an open confession of his dishonesty.

The sagacity of this faithful dog has not only saved his master's corn, but is likely to be a means of reclaiming the man, by an early exposure of his fault; for it seems he has been led away by some bad companions, who persuaded him to this attempt. $\mathrm{Mr}$. Palmer has taken great pains to convince him of the danger of such associates, and the enormity of his offence ; and the more effectually to preserve him from any further intercourse with them, and to remove him from a place where his character is lost, has prevailed with a friend of his in Shropshire to take him on trial, having first informed him of his misconduct. This last act of kindness entirely overcame him; he wept like a child, and made the most solemn promises 
of amendment. As he is young, and not hardened in vice, hopes may be entertained that he will keep his word, and afford his master the satisfaction of having, by well-timed lenity, saved a fellow-creature from ruin.

Dinner is announced: I have only time to bid you adieu, and close my letter.

Caroline. 


\section{LETTER XIX.}

FROM EMILY TO CAROLINE.

\section{DEAR CAROLINE,}

LONDON is not the field for natural history, nor did I expect, in this region of bustle and visits, to collect any instances of the sagacious faculties of the brute creation; but where the mind is intent on any single pursuit, there is no place so barren but may yield some supply of knowledge, nor any company so insignificant but may afford some gleanings worth preserving.

IVe joined a large family party a few days ago at my uncle's, where the younger part of the company was excused from the slavery of the card-table, and indulged with the enjoyment of free conversation. Amongst this cheerful group was a Westminster scholar, who related a curious fact of a blind heggar, who frequently solicits charity in that neighhourhood, particularly in Dean's Yard, accompanied by a dog, who is really a valuable friend to this poor man. He serves him as a guide, and conducts 
him from street to street with safety; but this office, though very useful, shows no unusual degree of intelligence. Many dogs are taught to lead the blind: this dog does more. When charitable people fling halfpence from the windows to his master, he searches carefully for them, picks them up with his mouth, and deposits them in the hand held out to receive them; and this he repeats, without being tired, whatever number of halfpence may happen to be thrown out. The dexterity of the dog in collecting the money, is an inducement for many to bestow the pittance for which the beggar pleads; especially the boys belonging to the school, who are highly amused with exercising the dog in his business, and trying to render the task more difficult by hiding the money in the mud. But whether he be guided by the scent of the copper, or the keenness of his sight, he seldom fails to find them.

This account interested the party: most of them found a story to relate, some of which are so curious, I must repeat them.

A dog belonging to Mr. Taylor, a clergyman who lived at Colton, near Wolseley Bridge, was accused of killing numbers of sheep. Complaints were made to his master, who asserted that the thing was impossible, because he was muzzled every 
night. The neighbours persisting in the charge, the dog one night was watched, and he was seen to get his head out of the muzzle, then to go into a field, and kill and eat as much of a sheep as satisfied his appetite. He next went into the river to wash his mouth or quench his thirst, and returned afterwards to his kennel, got his head into the muzzle again, and lay very quietly down to sleep." * This looks like a consciousness of doing what he ought not to do, and a determination to indulge appetite by stealth.

The same design is apparent in a horse, which had been observed to disengage his head from the halter, then to open the door of the stable and go out, in the middle of the night only, and regale upon corn in a field at a considerable distance from the stable. The horse returned to his stall before the break of day, and had continued this practice some time without being detected. He adroitly opened the door by drawing a string fastened to the latch with his teeth. And it is said that on returning to the stable he shut the door: but I am not so credulous as to attribute that to design, but rather to the

* Related by Miss Sneyd, sister to the late Mrs. Edgeworth. 
swing of the door, that closed after him without any effort to make it do so.*

It came next to the turn of a young lady to entertain the company on the same subject; who said she was not surprised at the adroitness of the horse in opening the latch, because she had heard of an instance of ingenuity in a cat very similar. "Some years ago," continued she, "a family in Waterford were alarmed by an outer door belonging to their house being frequently opened without any visible cause. At last, after many surmises, a cat was observed approaching the door, and striving to push it open; but, on finding it shut, she leaped up, put one paw on the handle of the latch, and with the other bent down the trigger till the latch was raised; then she let herself down, and pushed with her head against the door till it was sufficiently open to admit her. The family to whom this cat belonged saw her repeat the same feat several times." + “ Hunger, I suppose," said a gentleman, "was the stimulus to her contrivance. Goldfinches we often see obliged to obtain their drink by drawing up a little bucket, and their seed by lift-

* This anecdote was related to Dr. M`Donnel of Belfast, by a friend on whose veracity he could rely.

+ Mr. Boswell, of Belfast, can vouch for the truth of this anecdote. 
ing up the lid of a box ; which, though more common, is equally curious. A friend of mine," continued he, "Mrs. Attersal, of Crab Tree, near Fulham, had a pug-dog which learned to pull the bell whenever he wanted to be fed." I remarked, that these actions, so contrary to the habits of the animals in a state of nature, ought to be attributed to the power of acquiring new habits from instruction, and associating with man in a domestic state, rather than to instinct. "Your observation," replied the gentleman, "reminds me of a pig, which was brought up by the late Sir Henry Nildmay's gamekeeper amongst the puppies, at his seat in Hampshire, and, from imitation, learned to point; and afterwards assimilated his manners so much to those of the dogs with whom he had lived, that he became a destroyer of sheep. And, as a further proof of the capacity of different animals to receive new habits from education, I remember a badger at Lord Belmour's, which also points, and accompanies his lordship on his shooting expeditions. He is likewise useful in a way more congenial to his nature: he fishes for his master, and brings the salmon out of the water without offering to eat them."

This entertaining conversation was concluded by the relation of an affecting incident that happened some years ago, near Amboy, in the Jerseys, in 
North America. A child was accustomed, when it got its breakfast, to go beside the decaying trunk of a tree, in the cavity of which lodged a large black snake. With this reptile the child was observed to divide its breakfast, giving the snake, generally, every third or fourth spoonful of its pottage and milk. The creature, harmless whilst unprovoked, rested its head on its benefactor's knee, looking in her face, and seemingly counting the spoonfuls; but when, by neglect, it did not receive its due share, it then made so free as to attempt to help itself: but for this impertinence it often got a blow with the spoon and a reprimand. The friends of the child, conceiving that this extraordinary friendship might have dangerous consequences should a quarrel ensue, prevailed upon the child to entice the snake from its habitation, when they killed it without pity; and by the same blow might be said to destroy their child,-for when she saw the fate of her friend and companion, she wept and lamented so much, that it undermined her health and brought her to the grave.

Poor child! her sensibility was great. Had she lived to maturity, she would, in all probability, have made a most affectionate wife and mother. Yet, who could blame her parents for their apprehensions of the insidious disposition of her favourite? Who could have divined such an unfortunate result? 
My time has passed more agreeably than I expected; but, notwithstanding that, I am imaptient to return to Woodlands, and my father has consented to do so next week, when I shall hope to find a letter from you.

Your affectionate

EmiLY. 


\section{LETTER XX.}

FROM CAROLINE TO EMILY.

\section{DEAR EMILY,}

THE manner of conferring a kindness shows the delicacy of the benefactor's mind more than the kindness itself. Patru, a very learned Frenchman, was driven by poverty to the mortifying necessity of selling his library. Boileau, the celebrated poet, purchased it; and, under the pretence that he had not room for it at that time in his own house, suffered it to remain in the hands of the original possessor as long as he lived. There might possibly be many friends who would have presented him with his books; but how few would have done this generous action, without seeking the credit of it, or laying Patru under an obligation! In like manner, Mrs. Saville and my dear Rachel lighten the weight of my dependent situation by frequent declarations that their happiness is increased by my company. In return, I endeavour to render myself useful, but my ignorance of domestic affairs incapacitates me for those offices in which Rachel excels; for her wise mother has made it 
a point to instruct her in every branch of family economy. I am her scholar; and, though very awkward in my new business, I hope, whenever we meet, to regale you with puddings and preserves of my own making. It is one of my dear aunt's maxims, that nothing is trivial or mean that is useful; and that the comfort and order of a family depend rery much upon an attention to trifles. No part of her household escapes her observation; and she is desirous that I should acquire those domestic habits, which are so different from my former mode of life, that I should find them an unpleasant task, were it not for the example and condescension of Rachel, who not only instructs me, but also gives me her assistance, and lightens my labours by the pleasures of her conversation.

Mrs. Saville has just entered the house, with something in her hand, and summons me down stairs. I obey her call, and will resume my pen presently.

$$
\text { * } \quad \text { * } \quad * \text { * }
$$

An elm, near our house, was cut down some time ago, and the sawyers have been this day employed to divide it into planks. Upon cutting it up, they discovered a hollow place, nearly in the centre of the tree, containing a bird's nest, and several eggs, which 
the saw has unfortunately broken.* It was this nest that Mrs. Saville wanted to show me. How long it had lain in its recess cannot be known; but, as the yolks of the eggs were not dried up, one would suppose that it could not be a very long period. It is difficult to account for the circumstance altogether. That a bird should choose such an unfavourable situation for her progeny, is contrary to the usual sagacity of those creatures, whose maternal solicitude is so striking; and that any part of an elm, a slow-growing tree, should grow so rapidly as to enclose nest and eggs before they were destroyed by moisture or insects, is surprising; especially as, from the cavity in which it lay, to the surface of the tree, were four or five inches of solid timber. The fact is certain, though to me inexplicable: I relate it as it happened. Leaving it to your penetration to develop the mystery, I shall fill the remainder of my letter with the history of a pair of eagles, that have taken their abode on the estate of Doctor M'Donnel of Belfast. $\dagger$ This gentleman has a farm at Fair Head; (which is a very remarkable promontory in the north of Ireland, termi-

* This circumstance happened on the estate of Mr. Parker of Chelmsford, in the year 1807.

+ This account was communicated by a friend of Dr. M'Donnel's. 
nated by the greatest basaltic pillars, perhaps, in the world;) these rocks rise perpendicularly from the sea about five hundred feet, and afford an habitation to a pair of eagles, which breed annually in the inaccessible precipice ; and their nest has seldom, if ever, been disturbed by man. At a certain time the young eagles disappear, and leave only the two old ones, who seem desirous of holding undivided empire. To what region the young eagles emigrate, is not known. If one of the old ones is shot, another soon appears; so that a solitary bird is seldom seen, and no one ever observed more than two old ones. What seems singular is, that although there is a considerable number of sheep breeding and grazing on the plain below, and that these eagles live on lambs, they never molest them, but carry on their depredations in Rathlin, in Hantine, and the Highland islands. Whether this arises from something noble in the disposition of the bird, sparing or contemning what is immediately in its power, or from the design of reserving the prey that lies so near its grasp for some pressing emergency, must be left to conjecture.

The late Marquis of Antrim obtained one of these eagles, and confined it with a chain. This bird was long domesticated, but was often, from the carelessness of servants, fed on putrid meat, and sometimes so much neglected, that he became very hungry. 
When regularly fed, he ate freely, without being disturbed by the attention of the spectators; but if he had been long deprived of food, he would never touch the most delicious morsel that was set before him whilst any person was present. This strange conduct was supposed to arise from an apprehension of being deprived of the food of which he stood in so great need; and therefore he always kept himself in a posture of defence and vigilance to guard it when of such value; but when it was of less importance, he gratified his appetite without any precaution. From this account, it appears that these birds possess a degree of reflection that enables them to adapt their conduct to circumstances.

There seems a mixture of reason and instinct, which differs widely from that pure instinct that never deviates from its rule, and is chiefly observed in the inferior orders of animals, such as insects, reptiles, and zoophites. The elephant, the horse, and the dog, are peculiarly intelligent : instinct in them, on many occasions, is subordinate to a mental capacity, approaching to the reasoning powers of man. Could the habits of all creatures be intimately known, it might be easy to trace the gradations from reason to pure instinct; but the fierce inhabitants of the forest, and those that dwell in the depths of the ocean, besides numerous tribes that are driven by fear into the re- 
motest solitudes, are secluded from that notice which is requisite to ascertain the degrees of intelligence bestowed upon them. But, from what is known, it appears that the superior orders of quadrupeds, and especially those that associate with man, are the most sagacious. Birds also enjoy this privilege very highly, when the protection of their young is concerned. Mr. Galton, in his very entertaining work on birds, remarks, that blackbirds generally build low in bushes, or in trees that are not very high; and he mentions an instance of a bird of this species, after having built its nest twice near the bottom of a hedge, and both hatches of its young falling a prey to cats, the third time she placed it in an apple-tree, eight feet from the ground. To what can this be attributed, but to the effects of experience and design? Mere instinct teaches finches that build in green hedges, to cover their habitations with green moss; the swallow, or martin, that builds against rocks or houses, to cover hers with clay; and the lark, to collect vegetable straw for the same purpose, as approaching to the colour of stubble, amongst which she builds. But should either of these birds change the colour of the material of their nests on account of a different situation, I should attribute that alteration to a higher principle, by varying the mode of compliance with the instincts of nature in assimilating the colour of birds' nests to 
the situation in which they are generally placed; but the deviation from the usual course would mark a choice, and therefore be superior to the natural impulse that guides the parent bird to build her nest after a peculiar manner.

This subject has insensibly led me further than I intended: it is time to come to a conclusion, and bid you adieu.

CAROLINE. 


\section{LETTER XXI.}

\section{FROM EMILY TO CAROLINE.}

\section{DEAR CAROLINE,}

ONE of my favourite amusements is riding on horseback: I have a white pony that carries me most agreeably, and is so tractable that I am not under the least apprehension when I am upon him. As I have had him for these two years, I am much attached to him; but I shall love him better than ever, since I find that he is capable of friendship; and, what is a still rarer quality, does not shrink from defending his friend in the hour of danger. My horse is grown extremely fond of a little dog that lives with him in the same stable; and whenever I ride, the dog runs along by the side of my pony. It happened yesterday, as the groom was leading the pony out for exercise, that they met a much larger dog, who very violently attacked the diminutive stranger; upon which my horse rose on his hind legs, and, to the astonishment of the groom, so effectually fought his friend's battle with his fore feet, that the aggressor scampered off in a cowardly manner, without any further attempt to renew the 
attack.* I reflected on the circumstance, as a very extraordinary instance of deviation from the natural instincts of a horse, and related what had happened, to a circle of friends who had come to dinner. One gentleman paid more attention than the rest to my narrative, and allowed that, as a voluntary act, it was a very unusual instance of sagacity and affection; but as a horse in a state of nature probably fights with his fore feet, it was rather a deviation from his domesticated habits than from his instincts. The friendship of animals of different species appears to me very extraordinary, as they can have no natural sympathy with each other ; and I suppose that it seldom takes place except in a domesticated state, in which many examples of it are to be found, even when there is a natural antipathy between them. I have read, somewhere, of a peewit that was kept tame in a garden, but voluntarily took up its abode in the kitchen during the winter: it associated with a dog and a cat in the chimney-corner, and gradually became so familiar as to show marks of indignation if either of them interrupted him when he was washing himself in a basin of water kept for the dog to drink.

Miss Seward, of Lichfield, who wrote Memoirs of Dr. Darwin, mentions a favourite cat that had been

* The Most Rev. Dr. Plunket, Roman Catholic Bishop of Neath, was witness of this fact. 
broken of her propensity to kill birds, and lived several years without molesting a dove, a lark, and a redbreast, that were kept tame, and used to fly about the room where the cat was daily admitted. The dove frequentiy sat on pussy's back, and the little birds would peck fearlessly from the same plate out of which she was eating.

A gentleman at Belfast* had a dog that was remarkable for pursuing and destroying birds when abroad in the fields; but he overcame this propensity so far as to allow a tame quail to run through the house with him, lie before the parlour fire beside him, and when, from longer acquaintance, he had become more familiar, he suffered it to run over him, and seemed to look at it with great complacency, as if pleased that it trusted to his generosity.

Many creatures have carried this friendly disposition much further than mere association; for I have heard of several instances of the young of one race being nourished and protected by a female of a different kind; nay, even when the strongest antipathy naturally subsisted between them. Mr. White, of Selbourne, asserts, that a cat suckled a hare, which followed her about the garden, and came jumping to her call of affection.

* Mr. Templeton. 
At Elford, near Lichfield, a hare big with young was shot: the young were taken from the mother alive, and the cat, who had just lost her own kittens, carried them away, as was supposed, to eat them; but it appeared afterwards that she was excited by a different motive, for she suckled and adopted them as her own.

It happened that some humane person, near Plaistow, seeing a puppy struggling in a pond, drew it out half drowned: a cat, with truly maternal solicitude, licked, cleaned, warmed, suckled, and recovered it.*

Polito, in his menagerie, used to show a lion's whelp, that had been brought up by a bitch, who, though much inferior to it in size, acquired authority over it.

Cats seem particularly disposed to adopt the offspring of a stranger; but the most extraordinary instance that I have heard, was related to me by a lady, $\uparrow$ who was an eye-witness of the fact. Her cat had a litter of kittens, that were kept in a hamper in the cellar. In order to please her children, she one day went down to see them. On looking into the hamper, she found a young rat amongst the kittens, which she ordered to be taken out. But the next

* Related by William Darton.

+ Mrs. Bell, of Putney Heath. 
day it was again found, a quiet inhabitant of the same place; and there was no doubt that the cat suckled it, and was disposed to bring it up with her own family.

The Right Hon. George Ogle had a badger suckled by a cat, which had nearly endangered the life of its possessor; for he related the circumstance to Lord Muskerry, who showed marks of unbelief, which Mr. Ogle thought necessary to remove or resent as an impeachment of his veracity. He therefore sent his servant to Bellevue, in the county of Wexford, to fetch the badger, and convey both cat and badger to Lord Muskerry's house in Dublin. His lordship immediately recollected the smile of contempt with which he had listened to Mr. Ogle's recital, and entertained apprehensions of the consequence; expecting that his next visitor would be some friend of Mr. Ogle's, to demand an explanation of his behaviour. He wisely gave a pleasant turn to the affair, by sending to the fish-market for one of the finest turbots that could be got, and regaling the badger with it: he then returned the animal with this message : "Give my thanks to your master, and tell him that his badger has feasted upon the best turbot that could this day be purchased in Dublin." Mr. Ogle was well pleased with the welcome his 
badger had received, joined in the laugh, and the affair ended happily, which might otherwise have had a serious termination.

In return for your entertaining account of the eagles, I send you some particulars concerning the eels found in the river Ban, in the same part of Ireland, communicated to Mr. Craven by a friend who resides in that kingdom. An amazing quantity of food is supplied to the people by the eels and the salmon of this river, which, at different seasons of the year, constitute a large share of the riches of the country around. The bounty of Providence has so ordered it, that the one migrates to the sea, when the other is prepared to ascend the stream; so that the great lake and shallow rivers are always replenished with either the one or the other, as if they occupied their station alternately by agreement. They assemble to migrate, exactly as birds do, and seem to have the most exact intelligence of the time and the place of setting out, as well as that to which they direct their course: always returning, with the most unerring certainty, to the same river from which they had emigrated. The eel never attempts to descend until a flood arises, which, besides disturbing the transparency of the water, assists in forwarding the motion of the fish. They never proceed whilst the moon or stars are bright; 
but choose a dark, stormy night for their journey. One or two flashes of lightning will put a sudden stop to their advancement, when, in other respects, they are most completely arranged, and in a state of preparation. Numbers of them often gather themselves into a very curious ball of great magnitude, and rolling down the stream in this order, break through the nets, and all other obstacles which impede their progress. The fishermen being aware of this stratagem, seek for these balls, and, after breaking them with poles, catch the eels in their nets with greater facility. After the parent fish have escaped to the sea, they do not return; but the young eels venture back, and show surprising instances of sagacity in finding the rivers, and pursuing their track.

Your example, and that of the amiable Rachel, have reconciled me to the retirement of the country. You have taught me to find amusement where, formerly, my inattention overlooked those objects that now so greatly interest me. Natural history, that I considered as the province of philosophers only, I find, is suited to every capacity; and it needs only to acquire the habit of observation, to find a charm in every plant, and throughout all the tribes of animated nature. Not the minutest fly escapes me unnoticed: a frog, a spider, creatures that I once held in abhorrence, now afford me entertainment, and daily 
teach me the sublime lesson, That every part of creation displays striking marks of the wisdom and goodness of the Deity; who has amply provided for the enjoyment, as well as the preservation, of the meanest of his creatures.

The clock has struck eleven : I must retire to rest, after wishing you a good night.

EMILy. 


\section{LETTER XXII.}

FROM CAROLINE TO EMILY.

MY DEAR EMILY,

Nature, indeed, opens a delightful book, abounding with novelties at every page, to those who will read in it. The ignorant, the stupid, and the inattentive, equally overlook its beauties:- those innumerable harmonies, that so loudly proclaim the benevolent designs of Him who has so largely provided for the enjoyments as well as the mere existence of all creatures - has adjusted their form and organs to their instincts, and fitted them exactly to fill up the situation in the material world in which he has placed them.

St. Pierre has a passage, in his Studies of Nature, so applicable to my subject, that I cannot resist my inclination to quote it.* "Nature has adapted to plants, the smelling, the mouths, the lips, the tongues, the jaws, the teeth, the beaks, the stomachs, the chylification, and the secretions,-in a

* Hunter's translation, vol. i. p. 57. 
word, the appetites and instincts of animals. Each one chooses that best adapted to its habits and constitution. Thus, the goldfinch frequents the thistle, because he finds a rampart in its prickly leaves, food in its seeds, and materials for his nest in its down. The bird-fly of Florida, for similar reasons, prefers the vignonia. This is a creeping plant, which finds its way to the tops of the highest trees, and frequently covers the whole trunk. He builds his nest in one of its leaves, which he rolls into the form of a cornet: he finds his food in its red flowers, resembling those of the foxglove, the nectareous glands of which he licks: he plunges his little body into them, which appears, in the heart of the flower, like an emerald set in coral; and he gets in sometimes so far, that he suffers himself to be surprised there and caught."

The same author mentions other examples of these beautiful coincidences: one, in particular, occurs to my memory at this time. "The rhinoceros, an inhabitant of the torrid zone, is clothed with a hide rolled up in several folds. This clumsy animal has the appearance of being invested with a threefold mantle; but being destined to live in the miry morasses of India, where he grubs up with his horny snout the long roots of the bamboo, he would have been in danger of sinking, from his enormous weight, 
had he not been endowed with the strange faculty of extending, by blowing himself up, the multiplied folds of his skin, and of rendering himself lighter in proportion to the space he stands upon." **

The strong digestive powers of the dog's stomach, is another instance of the same harmonious agreement. His appetite teaches him to swallow bones, which, though not ground into powder with his teeth, are presently softened and dissolved by the extraordinary power of the gastric juice of his stomach.

The air-bladder peculiar to fishes, by the dilation or contraction of which they rise or sink at pleasure, enables them to live in an element that would be destructive to most other animals, but which is their destined habitation. Their organs of sight and hearing differ from those of other creatures, but are adapted, in a particular manner, to that medium through which they are obliged to see and hear. Their fins, as artfully contrived for swimming as the wings of birds for flying, display great variety of form, number, situation, and force, according to the habits and wants of their owners. The size and shape of the mouths of fishes would, probably, go far to ascertain the kind of prey they feed upon, as there is no

* Hunter's translation of St. Pierre's Studies of Nature, vol. i. p. 339. 
doubt but each is fitted exactly to its purpose. That of the sturgeon is placed under the head, without teeth, like the opening of a purse, which he has the power of pushing suddenly out or retracting as he pleases. Before this mouth, under the beak or nose, hang four tendrils, some inches long, so strongly resembling earth-worms, that his prey is deceived by them, and approaching too near, he seizes and devours it. The teredo, or ship-worm, feeds upon wood, for which its calcareous jaws are admirably adapted. They frequently attack the keels of ships, and force their way so successfully into them as to endanger their safety. They bore their passage in the direction of the fibres of the wood, and cannot return or pass obliquely; consequently, a knot is fatal to them. Between the years 1731 and 1732, these minute invaders caused great alarm to the inhabitants of the United Provinces, by their numbers, lest they should materially injure the piles that support the banks of Zealand.

Birds that feed on seeds and vegetables, resemble quadrupeds that eat grass, in the number of their stomachs, the length and size of their intestines, and the gentleness of their dispositions : whilst those creatures that prey upon others, whether birds or beasts, are armed with offensive weapons; such as claws, talons, horns, \&c.: they are likewise endued with 
great strength, and a ferocity of temper that is unsocial and forbidding. The appetites and the construction of the animal agree together, and mark, in the most striking manner, the design of an Intelligent Being, who has formed each species to fill exactly that place in the universe where his wisdom has fixed it; and so necessary is every order of creatures, even those we call noxious, to the welfare of the whole, that, were any kind annihilated by accidental circumstances, it would occasion a very injurious deficiency. This was experienced by the inhabitants of a certain district in Germany, who were annoyed by a great number of sparrows that ate their corn. The indignant farmers, determined to get rid of these voracious plunderers, offered a reward for their destruction. The hope of the prize put so many hands to work, that, in a short time, the district was cleared of sparrows. But observe the consequence: the next year they were so overrun with caterpillars, that they were obliged to procure sparrows to devour them. Thus it appears that every link is requisite to complete the chain; that there is nothing superfluous, nothing deficient; but that every part of this wonderful system depends upon each other, and is connected with the rest.

I am led to these reflections by the sermon $\mathrm{Mr}$. Palmer preached last Sunday, on the goodness of God, 
displayed in the provision he has made for the happiness of all creatures, according to their capacities, and the rank they hold in creation; rising from the insect, too minute for our inspection, to man. For our perception does not reach to the higher orders of created beings, whose felicity, doubtless, exceeds our comprehension as much as their nature is superior to ours. The gift of life, with its appropriate enjoyments, is infinitely diffused. The benevolent Creator has bestowed it upon the innumerable creatures that inhabit our globe, which, though it contains countless millions, is but a minute speck in the universe; since astronomy teaches us that system upon system rolls in boundless space, at distances that no imagination can comprehend. Nor can the discoveries of man extend to that point where there is a cessation of new worlds. Every improvement in our glasses discovers stars that have escaped the former observations of the most acute astronomers. Since all parts of our globe swarm with animal life- - the earth, the water, the air, each abounding in its own peculiar inhabitants, can we hesitate to believe, that the other worlds, that are dispersed in the regions of unlimited space, are likewise peopled with innumerable multitudes of living creatures, all partaking of the bounty of the Universal Father, rejoicing in their being, and, by their existence, displaying his goodness? My heart swells with gra- 
titude at the idea ; and though it is a task far beyond my powers to point out the individual instances that are daily before our eyes, yet I cannot resist mentioning a few of those sources of enjoyment that are bestowed upon ourselves, and which every person, who is in the full possession of his senses, is capable of appreciating.

The pleasures of sight delight us from our earliest years; and the whole visible world seems formed to gratify the eye. What beautiful effects are produced by the combination of the seren primary colours, displayed in the various tribes of animals and vegetables that surround us on all sides! From these seven colours proceed innumerable tints and shades of exquisite beauty and infinite variety. For our gratification in this particular is consulted, not only by the different hues of green with which nature distinguishes the classes of trees and plants, but likewise by the variety of hues displayed on the same individual plant: the leaves are of one colour, whilst the stem or the empalement is of another. In a similar manner, the parts of the same animal are variously coloured. Birds and insects excel in this respect; especially the latter. The wings of a butterfly, or the corselet of a rase-fly, may probably exhibit the assemblage of twenty colours, blended with the skill of an inimitable artist. 
The gratification of every other sense is provided for in the same abundant manner: fragrant odours for the smell, and flavours for the taste. The vicissitudes of winter and summer, spring and autumn, are a source of many pleasures, from the perpetual change that they occasion. These are all chiefly corporeal pleasures, and are enjoyed by man in common with the inferior orders of animals. Man is a being of a mixed nature, and derives his principal satisfaction from sources of a higher kind. The delights peculiar to him are intellectual: the pleasures of remembrance, the anticipations of hope, the pursuits of the understanding, the intercourse of friendship, the consolations of sympathy, the union of satisfaction with the exercise of virtue, especially the social and benevolent virtues; and, above all, the inexpressible recompense of a good conscience. These are the enjoyments bestowed upon us, with many others, by our beneficent Creator, in our present imperfect state of existence, which is only a passage to a more complete state of felicity. If we contemplate our being, and that of creatures below us, in this point of view, the goodness of the great Creator in the diffusion of happiness is most striking, and calls for the unfeigned praise and gratitude of all rational beings.

I have insensibly got into a very grave, but I hope not unwelcome strain, from the impression of $\mathrm{Mr}$. 
Palmer's eloquence, which, had you been present, would have much pleased you.

My letter is protracted to a great length: I leave you to fill up my deficiencies upon the unlimited subject of God's goodness to his creatures, and wish you good night.

Caroline. 
SUPERIOR INSTINCT OF CERTAIN ANIMALS. 18.5

\section{LETTER XXIII.}

\section{FROM EMILY TO CAROLINE.}

\section{DEAR CAROLINE,}

I WAS so far from thinking your last letter too serious, that, I can assure you, it rather increased my usual cheerfulness, by the consideration that the whole universe is under the direction of a Being infinitely wise and good. Amongst the multitudes of proofs of his provision for the happiness of man in particular, may be reckoned the superior instinct, or rather sagacity of some animals, especially dogs, which frequently renders them extremely valuable, and puts them on a level with humble friends. I have lately heard two or three stories that do honour to the canine race; and, though they are unconnected with each other, I think they will gratify your taste for such anecdotes, and shall therefore make no further apology for relating them.

A little boy, about two years old, the son of a cottager, was accustomed to go with his parents when they went to work. One day, when their attention was engaged, he strayed to a rocky cliff at no great distance, where, it is supposed, that, being wearied by 
his endeavours to disentangle himself from the rocks and briers, he fell asleep, and by that means was overlooked by his parents, who, as soon as they missed him, made diligent search for him wherever they thought there was a probability of finding him; but all their efforts were fruitless. They had nearly given up the hope of recovering their lost little one, and were on the point of yielding to the terrible necessity of losing him for ever without knowing his fate, when the dog belonging to the cottage was observed to go out with his food in his mouth; and this unusual act he repeated so often as to raise a suspicion that he had some extraordinary motive for doing so. Curiosity, and a faint hope that he had discovered what they had so ineffectually sought, determined them to follow him; when, to their inexpressible joy, by tracing his steps, they were led to their child; and, by the time they had got up to him, the dog was found giving the food to the boy, whom he had sustained in this manner for several days.* The attachment, the fidelity, and the sagacity of this animal, are beyond all praise.

The courage of dogs is sometimes surprising. Captain Beaufort, of his Majesty's ship Blisson, relates an extraordinary instance of that quality in a dog which

* This circumstance happened in Ireland. A story very similar is related in The Family Tour, which occurred to a shepherd in Scotland. 
was named after the vessel. "It happened," says he, " that a huge whale reared his unwieldy back out of the water, near the ship. Blisson barked: the whale, unused to such an attack, flapped the sea with his monstrous tail. Blisson was in an agony of ardour to be at him. The whale put his nostril to the water's edge, and snorted a river into the air. Blisson could stand that no longer, but jumped into the sea from our quarter-deck, and chased him. Calling and roaring were of no use. Fortunately, the whale thought proper to dive, or my Blisson would have fared worse than Jonah."

Mr. Capel Lofft, of T'roston Hall in Suffolk, had a dog that showed a most affectionate and tractable disposition. This dog was of that kind called by Bewick the elegant terrier. The poor animal had by some chance met with a severe injury, and, in the agony it suffered, took refuge in Mr. Lofft's court-yard. He was from home, and, from the spasms that affected the dog, the family apprehended he was mad. On Mr. Lofft's return, he discovered that the hurt was in the under jaw, and it was two years before it got well. Gratitude for kindness, at a moment when it was so much wanted, seemed to produce the most tender attachment in this dog. Mr. Lofft gained an extraordinary influence over him, and broke him of his propensity to seize rabbits and worry cats, merely by the 
displeasure marked on his countenance, without beating him. When he was most incensed against an unfortunate cat that happened to fall in his way, his master would snatch him up in his arms, and quiet him in an instant. Time rendered his attachment so strong, that it seemed as if no provocation could induce him to bite Mr. Lofft or the children. A dispute having, on some occasion, arisen between this gentleman and one of his little boys, after proper expostulation, he was attempting to put the child out of the room, who made resistance. The dog, seeing the bustle, supposed his master was going to beat the boy, and tried to pull him away by the skirts of his coat; which pleasing action gave such a turn to the contest as to reconcile the father and son.

The sensibility of this animal was also shown by his great fondness for music. He would sit for hours on a chair by the piano, listening to the soft strains of Clementi's or Pleyel's sonatas. And Mr. Lofft adds, that he has frequently seen him beat time with his tail whilst some favourite airs were playing.

Men and dogs are not the only animals influenced by musical sounds. The horses at the equestrian theatres, which move in measured steps, are all taught by music. And extraordinary stories have been related of the attention of spiders to music, though they have not fallen under the observation of any person with whom I am acquainted. 
My next example of canine virtue, if the expression may be allowed, is an historical record, and may have reached you before: if it has not, it will give you pleasure to see how far the animal feelings can approach to the moral virtue peculiar to rational and responsible beings; and what a union of the most affectionate and the most hostile qualities can exist in the same creature, both springing from a noble, generous disposition. "The fame of an English dog has been deservedly transmitted to posterity by a monument in basso-relievo, which still remains on the chimney-piece of the grand hall at the castle of Montargis, in France. The sculpture, which represents a dog fighting with a champion, is explained by the following narrative. Aubri de Mondidier, a gentleman of family and fortune, travelling alone through the forest of Bondi, was murdered, and buried under a tree. His dog, an English bloodhound, would not quit his master's grave for several days, till at length, compelled by hunger, he proceeded to the house of an intimate friend of his unfortunate master's at Paris, and, by his melancholy howling, seemed desirous of expressing the loss they had both sustained. He repeated his cries, ran to the door, looked back to see if any one followed him, returned to his master's friend, pulled him by the sleeve, and, with dumb eloquence, entreated him to go with him. The singularity of the dog's behaviour, 
added to the circumstance of his coming there without his master, whose faithful companion he had always been, prompted the company to follow the animal, who conducted them to a tree, where he renewed his howl, scratching the earth with his feet, significantly entreating them to search that particular spot. Accordingly, on digging, the body of the unhappy Aubri was found. Some time after, the dog accidentally met the assassin, who is styled, by all the historians who relate this fact, the Chevalier Macaire, when, instantly seizing him by the throat, he was with great difficulty compelled to quit his prey. In short, whenever the dog saw the chevalier, he continued to attack and pursue him with equal fury. Such obstinate virulence in the animal, confined to Macaire alone, appeared very extraordinary, especially to those who at once recollected the dog's remarkable attachment to his master, and several instances in which Macaire's envy and hatred to Mondidier had been conspicuous. Additional circumstances increased suspicion, and at length the affair reached the royal ear. The king (Louis the Eighth) accordingly sent for the dog, who appeared extremely gentle till he perceived Macaire in the midst of several noblemen, when he ran fiercely towards him, growling and attacking him as usual.

"In those rude times, when no positive proof of a crime appeared, an order was issued for a combat be- 
tween the accuser and the accused. These encounters were denominated the judgment of God, from a persuasion that Heaven would rather work a miracle than suffer innocence to perish with infamy. The king, struck with such an accumulation of circumstantial evidence against Macaire, determined to refer the decision to the chance of battle. In other words, he gave orders for a combat between the chevalier and the dog. The lists were appointed in the Isle of Notre Dame, then an uninclosed, uninhabited place. Macaire's weapon being a great cudgel, the dog had an empty cask allowed for his retreat, to enable him to recover breath. Everything being prepared, the dog no sooner found himself at liberty than he ran round his adversary, avoiding his blows, and menacing him on every side till his strength was exhausted; then, springing forward, he griped him by the throat, threw him on the ground, and obliged him to confess his guilt, in the presence of the king and the whole court. In consequence of which, after a few days, the chevalier was convicted upon his own acknowledgment, and beheaded on a scaffold in the Isle of Notre Dame." This curious narrative is translated from the Mémoires sur les Duels; and is confirmed by many judicious critical writers, particularly Julius scaliger and Montfaucon, neither of whom has been regarded as a fabricator of idle stories. 


\section{CONSCIENCE DISARMS THE MURDERER.}

The fate of the chevalier affords not only a striking example of sagacity, nearly approaching to reason, in a dog; but also teaches the impressive lesson, that the conscious guilt of a murderer disarms the boldest villain from defending himself; and that this horrid crime, however privately committed or artfully concealed, seldom fails of discovery, and often by means the least likely to produce such an effect.

Your faithful friend,

Emily. 


\section{LETTER XXIV.}

FROM CAROLINE TO EMILY.

\section{MY DEAR EMILY,}

That I may make some return for the amusement your canine anecdotes have afforded me, I will relate the feats of a simple dog or two, of low degree, when compared with your heroic avenger of his master's wrongs.

A gentleman, with whom my aunt was formerly acquainted, occupied a farm in a remote district of Scotland, and had a dog of the genuine colly, or shepherd's breed, named Gashkan, which signifies a hero, or my hero: this dog attached himself to one of the servants employed in the farm, who, being married, was boarded out of the house; but times growing hard, and his master indulgent, William and Gashkan often got a good dinner in the farm-house kitchen; the former by invitation, the latter by permission. Thus, dinner being ready became a matter of consequence to Gashkan; and such was his observation, that he soon 
learned to distinguish the signals of preparation. When it was near the time of summoning the servants together, a large pot of broth was set down on the hearth, and a long trivet table, usually raised up to the wall to make room, was let down; then the dairy-maid gave a loud call at the door, which was answered by the servants from the fields, and whilst they were on their way, she made every thing ready for their reception.

The men knew, by the shadows on the mountains, when the time drew near; and if one of them grew impatient, he would say, "Gro, Gashkan, see if dinner be ready." Gashkan set off instantly. If, on looking in at the door, he saw the pot on the hearth, and the table let down, he ran back with great alacrity, licked his lips, wagged his tail, and frisked about his master; but if he saw no preparation in the kitchen, he went slowly back, with his tail and ears drooping; and when asked if dinner was ready, slunk sheepishly behind his master. All this the servants understood, as well as if he had delivered a message.*

Mrs. Palmer's eldest sister is settled in America :

* Mrs. Grant, author of "Letters from the Mountains," "The American Lady," \&c. has obligingly furnished me with this, and several other curious anecdotes. 
she has been married several years to a gentleman who cultivates a large tract of land in a remote situation. This mode of life gives her an opportunity of observing the manners of animals in a wild state; and as she is a naturalist, and knows Mr. Palmer's taste, she does not fail to enrich her letters with much information that is novel and interesting. In her last, she gives the history and character of a favourite dog of a mixed breed, whose parents might have been supposed to be a Newfoundland and a colly, had the latter kind been in America. "This dog," says Mrs. Mackenzie, "possessed the most amiable disposition, and was always on the watch to please, which made her a general favourite. - Thus she lived, caressing and caressed. She was very useful in driving cattle off the bounds, and every other kind of service that such animals are accustomed to be employed in about a farm. The man-servant who lived with Mr. Mackenzie at this time, was of a rough, tyrannical temper, and often treated this fine creature very harshly; sending her to great distances, to save his own trouble, and beating her most severely for every mistake. Her patience and attachment, notwithstanding this behaviour, were astonishing.

* I was supplied with this account by Mrs. Grant. 
"After some time she had puppies, of which she was fond beyond expression. The servant being allowed to drown some of the puppies, pretended to understand the permission in a general sense, and destroyed them all. It is supposed, that his motive for this conduct was to prevent her from being detained from following and assisting him. In order to make you acquainted with the detail of her business, it must be premised, that the small extent of cultivated ground on Mr. Mackenzie's farm, was surrounded by a slight fence of wattled touch-wood, which was easily injured. Therefore, the first task in the morning, and the last at night, was to drive the wild cattle and horses from the vicinity, to a great distance in the woods, lest they should break these frail enclosures. Dugald, knowing the docility of his companion, trusted to her exertions for the performance of this duty, without stirring himself from the bounds. When she had driven them away, she would return, and look meekly in his face for approbation; but his usual reward was threats, frowns, and vociferations; upon which she would immediately set out again, and scour the woods without stopping, till she had driven the objects of her pursuit to an incredible distance. On returning a second time, breathless and exhausted, she would fawn on her tyrant, before she 
lay down to rest, and look up to him, with speaking eyes, for a token of approbation, which, if obtained, transported her with joy. Yet this gentle creature, so docile, patient of injury, and grateful for kindness, would, in defence of her master, and in obedience to his commands, attack the largest animal with courageous alacrity, and seemed insensible of fear, when any duty was to be performed. Miss Mackenzie, who was at this time about eleven years old, had several favourite animals, on whom she bestowed much attention; amongst these, Zara and a cat held the first place, of whom you shall hear more in the sequel. For some days after Zara missed her puppies, she went about moaning piteously, and seemed inconsolable. Her young mistress observed, with great concern, that, in addition to her maternal sorrows, this poor dog suffered much from the distention of her teats, which it was not easy to relieve; but, being very fond of her, she contrived to press out the milk with her fingers. The grateful dog testified her thanks for this service, by signs and gestures that made speech unnecessary. Zara had chosen a retreat for depositing her offspring, that, no doubt, appeared to her secure from invaders. A large house, near her master's, had been burned down: the sunk story remained full of rubbish; and there, in the oven which had 
belonged to the ruined kitchen, Zara's puppies were lodged.

" The cat, who was a great favourite also till she became a mother, when the new duties she had to fulfil made Miss Mackenzie more attentive to her propensities, had kittens much about the same time. The young lady then perceived a degree of levity and cruelty in her cat, that had before escaped her observation. She neglected her usual occupation of mousecatching in the cellar, and lay on the top of the house, watching for bats, all the evening. Not contented with this equivocal game, the bee-catcher, the gentle wren, and even the sacred swallow, were taken and devoured in the presence of her tenderhearted mistress, who tried every means to correct her voracious disposition. She confined her, she crammed her, and beat her with a dead bird, but still these atrocities were repeated. The appearance of the young family delighted Miss Mackenzie: she now determined to feed her well, and hoped she would assume a more domestic character, and live once more on milk and mice. Every preparation for the comfort of the little strangers was anticipated, and an excellent bed was made ready in the garret; but the cat, suspicious of the officious visits of her mistress, carried her young ones to a high projection near the roof, that had been intended for a pigeon-house. 
After having conveyed them out of the reach of Miss Mackenzie's kind offices, she would frequently abandon them for a whole day, climbing the tops of high trees in pursuit of wild game; whilst the cries of the little ones distressed her young mistress, as she was unable to afford them any assistance. The only means she had of diverting her chagrin, was in administering relief to poor Zara: but this amusement soon failed, for Zara disappeared, except when her services were required. The servants complained of strange noises in the garrets of a night, and the cat totally deserted her post. In this state of affairs, Miss Mackenzie frequently listened for the plaintive cries of the neglected little ones; but all was silent, and she was tormented with the idea that they had perished with hunger, aggravated by self-reproach for not having borrowed a ladder for their deliverance. Two days afterwards, she saw Zara coming out of the oven, as happy as possible, and observed that she did not come, as usual, to be relieved of her milk: the same thing happened several times, and at length curiosity induced Miss Mackenzie, with much difficulty, to descend to her retreat. She found her stretched at length in the great oven, and the five kittens sucking her with all their might; for her teats were so large, that they were obliged to stretch their mouths to the utmost, to effect their purpose. She brought 
up the whole litter: but whether their disposition was influenced by the nourishment of a foster-mother, is not mentioned."

Was it compassion, or the strong impulse of maternal tenderness, seeking an object to satisfy it, that overcame the instinctive aversion subsisting between dogs and cats? It is also difficult to discover by what means Zara knew that the kittens were lodged in a place to which she was supposed a total stranger; or, that they were abandoned by their mother ; and lastly, how such a large, heavy animal, could mount to so great a height, and convey the helpless creatures down. I can find no solutions to these enigmas: but such was the fact. Your ingenuity may probably account for them. I leave them to your consideration, and shall conclude this letter with one more short anecdote.

A lady who resided in Waterford, was in the constant habit of sending all her servants to a place of public worship in the afternoon of a Sunday. Orders were given that the kitchen fire should be made up, and the boiler put on to heat water for tea. One Sunday afternoon, as the family were sitting in the parlour, a little terrier, that belonged to the youngest daughter, came into the room, barking in an unusual manner, addressing herself, with dumb eloquence, to the mistress of the house, with whom she was seldom familiar. This drew general attention, and ex- 
cited a degree of alarm: the lady's curiosity being excited, she rose, and followed Fidele, who conducted her to the kitchen, where she found the boiler overturned, and the water streaming about the floor.

I am, with sincere attachment, your

Caroline. 


\section{LETTER XXV.}

\section{FROM EMILY TO CAROLINE.}

DEAREST CAROLINE,

Your story of Zara's adopting the kittens, so well authenticated and so extraordinary, prepares my mind for any instances of adoption that may be related by persons of credit. The power of finding their way back from vast distances, to a place to which they have been accustomed, which is possessed by various kinds of creatures, is a wonderful faculty, and in many cases seems unaccountable; nor do I think that the penetration of man can discover by what sense they are guided. Cats seem to excel in this unknown quality, though it is bestowed in different degrees on many other creatures.

Mr. Craven has a cat* that he calls the traveller. It belonged to his brother, who lived at Old Brompton, near London. A friend of this gentleman's, who was then going as master of a vessel to the West Indies, took a liking to this cat. She was given to him as a token of remembrance, and was carried from old Brompton, through London, put on board the

* The owner of this cat was Mr. R. Whitley, who lived at old Brompton, near London. 
ship, had performed the voyage, and returned to the wharf whence she set out. In all this long peregrination, she did not forget the home that had nourished her, nor the haunts to which she was attached. She took the earliest opportunity of making her escape, and finding her way through the intricate turnings and windings of the metropolis, arrived safe at her former residence, to the great surprise of all the family.

Had you or I been hastily carried, for the first time, through London, we could not have traced back our course, even the next day; whilst this cat must have remembered every turning, at the distant period of many months.

$\mathrm{Mr}$. Craven relates another incident, ${ }^{*}$ very similar to this. He knew a female cat belonging to Mrs. Farquarson, which was removed from Sampford Hall, near Saffron Walden in Essex, to Yosely Bridge in Hampshire, and, impelled by that invincible attachment to places, which is one of the characteristics of the cat kind, returned, as is supposed, through London, to the protection of her kind benefactress at Sampford Hall.

These feats are so far beyond any sagacity that I possess, that I am quite impatient to have my cuip. sity resolved upon the subject. Pray tell Mr. Palme: he is my oracle in natural history, and that I request he will explain in what this strange faculty consists.

* On the authority of Mr. Arthur Young. 
In imitation of your example, I spend some time every morning in the poultry-yard, which my indulgent father has fitted up in a very complete style, and peopled it with a great variety of domestic fowl, to gratify my taste. Amongst others, I have several wild-fowl that are grown tame : to these I pay particular attention, as I suppose their natural habits less changed than those which have been domesticated for many generations. The same diversity of disposition seems to prevail amongst the inferior classes of animals as amongst men. Some of the same kind are gentle and timid, whilst others possess a great portion of courage: and I have observed, that there is a kind of common language between the different species of these wild-fowl ; for the cry expressive of danger is communicated from one to another, and understood by all. I have a favourite widgeon, so tame that it follows me all over the yard: as I was scattering the corn this morning, a hawk hovered in sight, upon which a common hen gave the scream of terror, and the widgeon perfectly comprehending that an enemy was at hand, fled to me for protection, and remained crouched close to my feet till all apprehension of danger was past.*

One of my hens has surprised me very much, as

* Related by Mr. Templeton. 
she appears to have acted more from experience than instinct. Before I was aware of her design, the dairy-maid had set her on a clutch of duck-eggs: when they were hatched, she showed the usual anxiety at their going into the water, and made a very attentive, good mother. Her next brood was chickens, which, I suppose, from recollection of the success of her former charge, she immediately led to the water: in consequence of this mistake, they were drowned.*

During a few days' stay in London, I went to see the entertainment of the Blood Red Knight, at Astley's Riding Theatre, in which a horse is introduced, that mimics death so completely, that he suffers himself to be handled and examined, without showing the least voluntary motion, or any symptoms of life or feeling. The docility of this creature, and the skill of his teachers, are truly astonishing; but not more so than that of some elephants belonging to Rayobah, an Asiatic chief, once in alliance with the English.t

The elephants form a necessary and important appendage to a Mahratta camp, and are attended with the greatest care, and fed on the choicest food, even

* Mrs. Smith, of Parndon.

+ Communicated by James Forbes, Esq. to whom I owe many obligations, for miscellaneous observations scattered in this work. 
in times of scarcity, particularly when on hard service. Besides their vegetable diet, they are fed with rich balls, called massuulla, composed of spices, sugar, butter, and other expensive ingredients, especially in a camp, where every thing was extravagantly dear. This rich food was necessary both for the elephants and choice Arab horses, in a country every where laid waste and destroyed by the enemy, and affording but little provender. A scarcity of food, therefore, for man and beast, is no uncommon circumstance in warlike expeditions in India. But, however others might suffer from want of daily sustenance, there was an ample allowance for the favourite elephants of the Mahratta sovereign; yet they pined away, and grew emaciated without any apparent cause. At length the keepers were suspected of defrauding them of their massaulla; as the delicacies in these balls composed likewise the most expensive and savoury parts of the pilaus, curries, and other dishes eaten by the Moguls, and too costly for persons in their situation to purchase. The Master of the Elephants, who, like the Master of the Horse in Europe, is generally a man of rank, then appointed inspectors to see them fed, and the elephants regained their strength, and, for a time, appeared in good condition. But in a few months they fell off again, to the great astonishment of the inspectors, who daily saw them fed, frequently ex- 
amined the massaulla, and found the ingredients of the best quality. At length the cheat was discovered, and shows the extraordinary influence the keepers had obtained over these docile animals. They taught them, in the inspectors' presence, to receive the balls, and to put them into their mouths with their trunk, but to abstain from eating them: and these tractable creatures actually had that command over themselves, that they received this food, of which they are so remarkably fond, and placed it in their mouths, but never chewed it; and the balls remained untouched until the inspectors withdrew; they then took them out carefully with their trunks, and presented them to the keepers, accepting such a share only as they were pleased to allow them.

This story was related to me by that cousin of Lord Ormond's, who lately returned from the East Indies, where he has resided many years. His name is Hervey: he is a man of an agreeable person, engaging manners, and great observation. From him I have collected several anecdotes of animal biography, that will entertain you when I have leisure to repeat them. He is a frequent visitor at Belvoir Lodge, and I am mistaken if, in spite of Charlotte's ambition, he has not made an impression on her heart that it will be difficult for her to efface. It will be a happy circumstance if this attachment has 
a beneficiai influence in correcting her faults, and improving her character. It is a favourable symptom, that she listens patiently to his friendly hints, though she is indignant towards any body else who takes the liberty of pointing out her faults.

Mr. Hervey had an elephant* of which he was very fond; it had carried him many a long march, and had attached him to it by the sweetness of its disposition. If he wished to enjoy a prospect, he had only to speak, and the elephant remained immovable till he gave it the signal to proceed. If he had a desire for the ripe mangoes that grew on the upper branches, it advanced to that part of the tree, and, breaking off the most fruitful bough with his trunk, he offered it to the driver, for the company in his houdah; and if he received any part for his trouble, he accepted it with a profound respect, making a salaam, or obeisance, three times, with his trunk raised to the top of his head, in the manner of the oriental salute; and as often did he articulate his thanks by a murmuring noise,-his mode of expressing his gratitude. When a branch seemed likely to intercept the houdah, he twisted his trunk around it, and, although several feet in circumference, he broke it off with ease. This gentle animal was accustomed to visit his master at

* Mr. Forbes's account of his own elephant. 
the tent-door during breakfast, to be treated with a little sugar-candy from his tea-cup ; and no spaniel can be more innocently playful, or fonder of those who take notice of him, than this docile animal was.

These creatures are highly valued in the oriental part of the world, both as appendages to royal pomp, and for their many useful qualities in peace and war. In a camp they only carry the thrones and castles of the sovereign and his principal officers; and are sometimes kept in rich caparisons, merely for parade. They are a common present among the Asiatic prinees and generals of high rank. When properly disciplined, they know their duty, and are as obedient to the word of command as a rational being. On emergencies, they can travel two hundred miles in forty-eight hours; and will hold out for a considerable time at forty miles a day. Some of the largest of them are from eleven to twelve feet high. They are mostly of a dark grey colour, nearly black; but the face is generally painted with a variety of tints: and the tails and legs of the favourite horses belonging to the wealthy Indians are dyed of a crimson or orange colour. The elephant bred to war will stand firm against a shower of musket-balls, and will never give way unless mortally wounded. Mr. Hervey has seen an elephant * with upwards of

* From Mr. Forbes's account. 
thirty bullets lodged in the fleshy part of his body, but perfectly recovered from the wounds. All are not equally docile. When an enraged elephant turns round to retreat, nothing can withstand its fury; the driver has no longer a command, and friends and foes are involved in undistinguished ruin,

Such is Mr. Hervey's account of this noble animal, which, coming from an eye-witness, I thought would be particularly acceptable to you and your Cambrian friends, to whom I desire my regards.

Emily. 


\section{LETTER XXVI.}

FROM CAROLINE TO EMILY.

\section{DEAR EMILY,}

I sHould not have written so soon, had not I met with a circumstance that I think worth your notice; as it is a striking confirmation of a pleasing truth that I have long cherished, though without daring to assure myself that the thing existed, as it seems to bring animals too much on a level with human creatures. I am now convinced that, though the brute creation is not capable of acting virtuously from a principle of duty, and that grand stimulus that man enjoys, of the hope of a future reward, they are, nevertheless, often endowed with virtuous dispositions, such as gratitude, attachment, docility, and other amiable propensities, of which I give you the following example.

A farmer* in our neighbourhood had a bull so

* The facts here related are taken from the Monthly Magazine for October 1810. 
wild and ferocious, that he was kept constantly chained, except when led to water, \&c. at which time he was never suffered to be out of the hands of a trusty person. This animal seemed to have conceived a particular antipathy against the farmer's brother, who assisted him in his business, and had probably irritated him on some occasion, without being aware of the consequences. He never saw him approach the open shed in which he was kept, without beginning to bellow most dreadfully, which he continued as long as the object of his dislike was in view; at the same time tearing up the earth with his horns, and showing every symptom of the utmost aversion. On two occasions, while leading to water, he very cunningly watched an opportunity, and endeavoured to make a sudden spring out of the hands of his attendant at his enemy, who was standing in the yard.

While the bull was under the influence of hostility and resentment, one of the most tremendous thunder-storms ever remembered in this country occurred. The lightning resembled sheets of fire, and each flash was instantly succeeded by a thunderclap as loud as if a volley of ten thousand cannon had been discharged. The piteous roarings of the bull during this convulsion of the elements were quite affecting. Being exposed in an open shed to 
all the fury of the storm, he sent forth, every instant, a yell of terror hideous beyond description. Imagining that it was the lightning that chiefly alarmed the animal, the farmer proposed to the menservants to go and remove him into the barn, but in vain : they were so much terrified at their own danger, that the roarings of the bull made no impression upon them, nor could any of them be persuaded to move. The farmer's brother, who is a humane, generous young man, undertook the task, facing at once the double danger of the lightning and the fury of the bull. He accordingly put on his great-coat, and went into the yard. The moment he approached the bull, which he found lying, trembling, on his back, having almost torn his chain through the gristle of his nose in his efforts to get loose, he rose, and, by his fawning actions, expressed the delight he felt at the sight of any thing human amidst such a scene of terror. Fear had disarmed him of his ferocity: with the utmost quietness he suffered himself to be untied and led to the barn, by the very man whom, a few hours before, he would have torn in pieces if he could have got at him.

The next morning, as his deliverer was crossing the yard, he remarked that the bull, which had been replaced in his shed, no longer saluted 
him with his accustomed bellow. It struck him that the animal might remember his kindness to him the night before. $\mathrm{He}$ accordingly ventured, by degrees, to approach him; and found that now, so far from showing any dislike to him, he suffered him, with the utmost gentleness, to scratch his head. And, from that very day, he has continued to him as tame as a lamb; suffering him to play all manner of tricks with him, which no other person about the farm dares attempt, and seeming even to take pleasure in being noticed by him.

A more striking instance of a sudden transition from hatred to affection can scarcely be found, and one in which the cause was so clearly marked. It was not the change of caprice, but of something like reason, arising from gratitude to a benefactor. A practical lesson may be derived from this anecdotethat even the most savage dispositions may be subdued by gentle treatment. And yet, how seldom it is attempted to manage animals by any thing but harshness! Does this arise from inhumanity, ignorance, thoughtlessness, or the love of tyrannic sway? From each of these causes, I believe; and sorry I am to say, that the same injudicious system is often exercised towards children, whose tender dispositions are changed to perverseness and obstinacy by 
the use of the rod. Mrs. Saville often says, that blows never eradicated a vicious propensity: they teach the dear innocents to deceive from fear, but not to correct themselves; and since she has been a parent, she has never been known to give even a hasty slap. The amiable character of my dear Rachel is the best proof of the excellence of her sentiments on this subject. The equality of her own temper enables her to govern that of others, without the necessity of recurring to severity. But I have almost lost sight of my original subject - the virtuous disposition of animals. I have already given you an instance of gratitude, I will now entertain you with one of affection.

In the spring of 1803 , Miss T. in compliance with the request of a little boy, who had attempted to rear a nest of grey linnets, took the only survivor under her protection. For some days she kept the little bird in her bosom, to supply the warmth of its nest, and fed it frequently with the most delicate and nourishing food; and at night, instead of placing it in a cage, she laid it on the pillow, close to her face, and rose at daybreak to give it food. In short, she accomplished her task by the most assiduous care, and soon had the satisfaction of seeing her little charge able to feed itself and sit on the perch. This kindness was repaid by the 
strongest attachment on the part of the bird. $\mathrm{Ex}$ cept when he was feeding, he sat continually on her head or her shoulder; and if she left him but for a short time, he would instantly fly to her with expressions of joy, hover round her in ecstasy, and warble to the utmost stretch of his voice; then fly to her lips, and kiss them with transport. In a few months, being obliged to leave Ireland, she offered, though reluctantly, to resign her favourite, which she had named Ariel, to. his first owner. The little boy, sensible of the pains she had taken, and the attachment she had formed, generously made her a present of the bird, which she brought with her to England.

Ariel continued to show her, every day, if possible, stronger marks of attachment, not unmixed with jealousy; for if she was absent for a day or two, which sometimes unavoidably happened, he appeared dull and discontented, and seldom sang: yet the moment he heard her voice, or even her step, at a distance, which he distinguished from every other, he would fly to her with delight; but, as if recollecting that she had offended him, he would scold her, which he does whenever any thing displeases or frightens him, and be sullen for a long while, sitting on his perch in a fit of ill-humour. When his anger was abated, he would try to make 
amends for his displeasure, by kissing her lips, and feeding her with the seeds he had shelled, or throwing up from his maw the food he had previously swallowed, putting it into her mouth with his bill, as if she had been a young bird; then he would settle on her shoulder, and remain there without attempting to regain his liberty, though she sometimes ventured into the garden with him in that situation. After staying three years in England, Miss T. returned to Ireland, and carried her favourite with her, who is still living, and as fond of his mistress as ever. $\mathrm{He}$ is prone to take dislikes to strangers, especially if meanly dressed; and he never fails to testify it by scolding like a parrot; and when he has once shown symptoms of aversion, nothing can overcome it, but he repeats the same sounds upon the appearance of the person, whom he recognises though in a different dress. He has a great abhorrence of scarlet or full red, and seems terrified at a red coat, a shawl, or a standard of colours.*

This extraordinary account proves that birds are capable of attachment towards particular persons; a quality that renders them as amiable as they are beautiful. In those species that form permanent

* These circumstances were authenticated by a lady of respectable character. 
attachments of the conjugal kind, the instances of affection towards their mates are so striking, and so numerous, that it would be an endless task to particularize them; but I cannot resist mentioning one that happened under my own eye since I have been in Wales. Mrs. Saville had a pair of beautiful peafowls, that were the chief ornaments of her poultryyard, and remarkably fond of each other. It happened, unluckily, that a fox, who had been for some time the depredator of the neighbouring henroosts, found his way into our yard, and, in an unguarded moment, seized the poor peahen, and carried her off. The robber, by some accident, being disturbed in his flight, left his prey undevoured in the hedge at the bottom of the orchard. The body being found, was brought home, and after being honoured by the lamentations of the whole family, was deposited upon the dunghill. In the mean time, the peacock missed his companion, and with anxious search paraded about the yard, till at last he discovered her remains, and, no doubt hoping to cherish her with his warmth, sat down upon them, and continued his post for three days, till, finding all his efforts ineffectual, he at length gave up the attempt.

Dogs have frequently watched by their masters' 
graves, but I know no other example of a bird's maintaining the same constancy after death.

Homer relates that the dog of Ulysses recognised his master, though disguised in the garb of a beggar, and was so overpowered with joy, that he expired at his feet. The incident was probably the creation of the poet's imagination; but he wrought his interesting narrations on the undeviating laws of nature, or his immortal works would not have afforded such exquisite delight to so many succeeding generations. Therefore, though uncommon, it is not improbable that a dog should die through excess of joy at the return of a beloved master, after an absence of several years. As you may prefer the story in verse, I give you the following lines.

"When wise Ulysses, from his native coast Long kept by wars, and long by tempests tost, Arriv'd at last, poor, old, disguis'd, alone, To all his friends and e'en his queen unknown :

In his own palace forc'd to ask his bread, Scorn'd by those slaves his former bounty fed, Forgot of all his own domestic crew,

The faithful dog alone his master knew.

Unfed, unhous'd, neglected, on the clay,

Like an old servant, now cashier'd, he lay ;

And though e'en then expiring on the plain, Touch'd with resentment of ungrateful man, And longing to behold his ancient lord again, 
Him when he saw, he rose, and crawl'd to meet, 'Twas all he could, and fawn'd, and kiss'd his feet :

Seiz'd with dumb joy, then falling by his side, Own'd his returning lord, look'd up, and died.'

The close of evening compels me to terminate my letter, with assurances of undiminished affection.

Caroline. 


\section{LETTER XXVII.}

\section{FROM EMILY TO CAROLINE.}

\section{DEAR CAROLINE,}

Mr. Hervey is often at the Lodge: he takes pleasure in entertaining us with an account of the productions of India, and, as natural history is his favourite study, the instincts or sagacity of the animals are frequent topics of our conversation. $\mathrm{He}$ agrees with you in thinking that many individuals of the inferior classes of creation exhibit virtuous propensities that render them strikingly amiable. In support of this theory, he told us, that as he was one day shooting under the cubbeer-burr, a species of grove I will describe hereafter, he chanced to kill a female monkey, and carried it to his tent, which, in a short time, was surrounded by forty or fifty monkeys, who made a great noise, and, in a menacing posture, adranced towards the door. He took up his fowlingpiece and presented, upon which they retreated a little, and appeared irresolute; but one, who, from his age and situation in the van, seemed the head of the 
troop, stood his ground, chattering and menacing in a furious manner; nor could any efforts with the gun drive them off. $\mathrm{He}$ at length came close to the tent-door, and finding that his threatenings were of no avail, he began a lamentable moaning, and, by every token of grief and supplication, seemed to beg the body of the deceased. After viewing his distress for some time, it was given to him. He received it with a tender sorrow, and taking it up in his arms, embraced it with conjugal affection, and carried it off to his expecting comrades. The artless behaviour of this poor animal so powerfully wrought on Mr. Hervey and his companions, that they resolved, in future, never more to level a gun at a monkey.*

The famous banian-tree, (Ficus Indica, ) called by the Hindoos cubbeer-burr, is one of the wonders of their country.t A considerable part of this extraordinary tree has been swept away by the high floods of a neighbouring river, but what still remains is near two thousand feet in circumference, measured round the principal stem: the overhanging branches, not yet struck down, cover a much larger space; and under it grow a number of custard-apples, and other

* On the authority of James Forbes, Esq.

+ James Forbes, Esq. who relates these particulars from personal inspection. 
wild plants. The large trunks of this single tree amount to three hundred and fifty; the smaller stems, forming into stronger supporters, exceed three thousand; and every one of them is casting out smaller branches, and hanging roots, in time to form trunks, and become the parents of a future progeny.

According to the superstition of the Hindoos, the origin of cubbeer-burr is ascribed to one of their saints, who, long ages ago, invoked a blessing from Brahma on a small sprig of a banian-tree which he stuck into the ground on this spot, and prayed that it might overshadow multitudes. It is, probably, some thousand years old, and the Hindoos behold it with peculiar reverence. Indeed, we cannot be surprised at their affection for these verdant blessings in the torrid zone. On sacred festivals they repair under the shade of cubbeer-burr, to worship their respective deities, and perform their ablutions in the surrounding stream. This magnificent pavilion is filled with a variety of feathered songsters, peacocks, and other birds; and crowded with whole families of monkeys, whose antics are very diverting; showing their parental affection, by teaching their young to procure their food, and exert themselves with agility in jumping from bough to bough, and then taking more extensive leaps, from tree to tree; encouraging them by 
caresses when timorous, and menacing, and sometimes beating them, when refractory.

These animals show a curious instinct in their method of destroying the snakes which infest these trees : as if fully aware of their malignity, they seize them when asleep by the neck, and ruming to the nearest flat stone, grind down the head by rubbing it with great force on the surface; frequently looking at it, and grinning at their progress. When they are convinced that the venomous fangs are destroyed, they toss it to their young ones to play with, and seem to rejoice in the destruction of the common enemy.

The sagacity of the monkey tribe, in a wild state, seems to approach very near to reason: when domesticated, they gain more credit for intelligence than they deserve, from their extraordinary powers of mimicry. Some time ago, a lady of rank* had a present sent her, of a parrot and a monkey, by the same ship. These animals became very sociable and fond of each other. The monkey one day observing the cook pluck a fowl, and thinking that he could perform the same feat, took it into his head to try the experiment upon the poor parrot, and presently stripped her of all her feathers.

The same monkey, after he came to England, hap* Lady Mary Talbot. 
pened to see the poultry killed, and was so dexterous a mimic, that, getting into the hen-house, he twisted the necks of a vast number of chickens in a trice.

I delight in tracing the amiable affections, even in animals, and hope you will collect some more instances of the same nature.

I enclose a paper given me by Mr. Hervey, with a general account of the monkey tribe, that, I think, will afford you an half-hour's amusement.

Your very sincere and affectionate friend,

EMiLy.

That class of animals called apes, seems to excite peculiar interest, from the resemblance of their figure to that of man, their capacity of walking upright, and their propensity to imitation. We are apt to attribute to them peculiar sagacity, from their comical tricks; though it seems, that many other animals far excel them in their wild state, as to their natural habits, and the policy of their communities. Their form, indeed, approaches to ours; yet it is but a hideous resemblance, characteristic of vice and deformity. The satyrs and bacchanals in heathen mythology 
were symbols of every inordinate passion: the model from which they were delineated was evidently taken from the ape tribe, as may be seen by the strong similitude of the countenances of the one to the other. Nor does the disposition of these creatures falsify their physiognomy: many species are said to be fierce, ill-natured, malicious, revengeful, thievish, mischievous, and immodest; exhibiting a picture, if it may bear that term, of man in the most debased condition, a slave to vice and his own urrestrained inclinations. Yet these creatures are domestic favourites, and, it must be confessed, that some of the smaller tribes are not always destitute of beauty, if considered as an animal, and not as a counterpart to the noble, intelligent race of mankind. The ribbednose baboon, though disgusting in shape, is adorned with a variety of beautiful colours. Its nose is marked with broad ribs on each side, of a fine violet blue colour: a vermilion line begins a little above the eyes, and running down on each side of the nose, spreads to the tip of it. The insides of the ears are blue, which gradually softens to a purple, and terminates in vermilion. The rump is of the same colour; and the beautiful tints on the hips are gradations from red to blue. The beard is dark at the roots, orange at the middle, and yellow at the ends. But all this finery does not make him amiable, for his 
manners and disposition are odious. The upper parts of the body and tail of the green monkey, are covered with beautiful hair of a fine green colour, which enables the creature to conceal itself amongst the foliage of the trees : the throat, belly, and under side of the limbs, are of a silvery whiteness, which, with its diminutive size, must render it an object of admiration; it being not much above eight inches high, though the tail is eighteen inches long, and probably serves it for an arm, by which it clings to the brancines of trees.

The orange monkey is nearly the size of a squirrel : its head is round, eyes remarkably lively and brilliant; ears large; the body covered with short, fine hair, of a shining gold colour; and the tail is long.

But the most beautiful of this tribe is the mico, or fair monkey. Its head is small and round; face and ears of so lively a scarlet, that they look as if they were painted. The long white hair that covers its body is of a silvery whiteness, which is contrasted by the shining dark chesnut-colour of its long tail. As they diminish in size and increase in beauty, they appear to lose the ferocious disposition of the larger kinds of baboons, and are gentle, playful, and amusing.

The race is divided by naturalists into the three classes of apes, baboons, and monkeys. Apes have 
no tails, walk upright, and have a nearer resemblance than their fellows to the human form; having calves to their legs, and their hands and feet shaped nearly in the same manner.

The baboon has a short tail, a long projecting face, sunk eyes, and generally walks on all fours, unless compelled, in a state of servitude, to walk erect. Some of them are as tall, and have as much strength, as the most powerful men. Their propensities and figure are altogether most disgusting.

The monkeys are a more diminutive race: their tails are generally longer than their body, and, in many species, serve, from their flexibility, the purposes of an arm, by which the animal clings with safety to the upper branches of the tallest trees.

However the frolicsome temper of this latter division may introduce them as playthings into our houses, it is most unaccountable that reasonable beings should ever consider them as objects of worship; yet, from the relation of many respectable travellers, it seems an undoubted fact that, in many parts of India, magnificent temples are erected in their honour. In Amadabad, the capital of Guzerat, there are three hospitals for animals, where lame and sick monkeys, or others who find out this luxurious asylum, are fed with dainty fare. It is much to be feared that, 
whilst this improper indulgence is superstitiously bestowed upon brutes, many of the human race, in the same country, languish through want and neglect.

The amusing tricks that are told of the animals of this genus in a state of captivity, though they show their capacity of being taught, and evince their sagacity, yet they do not inform us of their instincts or natural habits: for them, we must have recourse to the accounts of travellers who have visited the torrid zone, where all the species, except the Barbary ape, are found.

From the oran otan to the smaller kinds of monkeys, the varieties are very numerous : their habits, of course, differ according to their species, as it is said that they never mix with each other, but live apart, each kind preserving its own domain. Most of them live in very numerous communities; but the oran otan is a solitary animal, and prefers the most desert places. Though they are frequently six feet high, they are active, strong, and bold: they live on vegetable food, except, occasionally, they meet with shell-fish on the sea-shore. Notwithstanding their size, they are extremely nimble, and chiefly rest in high trees, where they are secure from the attacks of all rapacious creatures, except their insidious enemies the serpents. It is asserted that they construct 
something like a hut, not only as a shelter from the heat of the sun, but also as a convenient retreat for the females and their young. They are so courageous as to drive elephants away from their haunts; and defend themselves with sticks, or by throwing stones, when they are enraged. A single man is by no means a match for them. Bosman relates that two negro slaves happened to fall in with several of these dangerous creatures on the coast of Guinea, when, the apes having overpowered them, they were just on the point of pushing out their eyes with sticks, as a party of negroes came up and rescued them.

On dissecting the oran otan, there are many essential distinctions in the internal formation from that of a man, though in some parts the affinity is so great, that their inferiority can only be attributed to the want of reason, or a deficiency in those intellectual powers that raise the human race above all other creatures. The tongue and the organs of the voice are similar; yet the oran otan is dumb. In the appearance and arrangement of the brain no differerence can be perceived; but the oran otan is irrational. Buffon concludes from these circumstances, that mind does not depend upon any conformation of matter, but is of a nature superior and independent. 
The residence of wild animals being generally far removed from the habitations of man, it is difficult to trace their instincts; especially of those species that seclude themselves in the recesses of woods and forests, where few ever enter but hunters or wanderers, who are too much engaged in securing themselves against danger, to observe attentively the habits of the creatures around them. Some particular's have, however, been collected of different species of the ape genus, which are worth your notice.

The pigmy ape is found in the southern parts of Africa : it lives in woods, and feeds on fruits and insects. If wild beasts attack them, they assemble in troops, and defend themselves by throwing a cloud of sand behind them, which blinds their pursuers, and renders their escape easy. This action shows great sagacity, and appears to be the result of reflection. They act in concert, as is seen from their plundering gardens or plantations in a large body; whilst one of them is always stationed on an eminence as a watchman, to see that no enemy is at hand. If all is safe, he makes it known by a signal that sets them all to work; but if he perceives any one approach, he warns those on the ground to run up the trees. If it is necessary to abandon their project, they will pursue their route, by leaping from tree to 
tree, till they reach the mountains. The females, in these flights, are frequently laden with three or four young ones, clinging round their necks and backs; but this burden does not prevent them from making surprising leaps, both as to distance and swiftness.

Tavernier gives an extraordinary instance of the malicious and revengeful disposition of the Barbary ape. As he was travelling with the English president in the East Indies, they observed a great number of large apes upon the neighbouring trees. The president, amused by an appearance so novel to him, wished to have one shot for a nearer examination, though the natives who attended him represented the danger of exciting their vengeance. In compliance with the president's request, Tavernier, however, brought down a female with her little ones. In an instant, her companions, to the number of sixty at least, descended in fury, and crowded upon the president's coach; where they would presently have dispatched him, had not the blinds been immediately closed, and the apes beaten off by the numerous attendants. The flesh of this species is eaten by the wild Arabs.

The baboon is very formidable, from its great strength, ferocious disposition, and extreme agility. One of them at liberty will easily overcome two or 
three men, which may be partly attributed to their sharp claws. They store their food in their cheekpouches. One of them kept in confinement, was known to hide eight eggs at a time in this manner; and when he had a convenient opportunity, he took them out one at a time, and after breaking them at the end, swallowed them deliberately. They plunder gardens and orchards with the same precautions as the apes, and dexterously fling the fruit from one to another, in order to carry it off more expeditiously; but if disturbed, they break it to pieces, and cram it into their cheek-pouches. At the sight of a man, they run up the trees, chatter, and shake the boughs at him with incredible boldness. The roots of bulbous plants are one of their favourite repasts: they dig them up, and then peel them with great cleverness, leaving heaps of the outside skin where they have been feasting.

The hare-lipped monkeys go also in troops, and are inexpressibly injurious to the plantations of millet, which they carry off under their arms, and in their mouths. They examine every stalk they pull up, and are so delicate in their choice that they reject more than they consume.

The Chinese monkey, when fruits are scarce, repairs to the sea-shore, and catches crabs by putting its tail between their pincers; and when they are closed, runs 
off with its booty, and devours it whenever convenient. It also contrives to get at the kemel of the cocoa-nut, but without losing the milk. The natives take the advantage of their fondness for this fruit, by laying some of them, after boring a hole through the shell, near their haunts: the first monkey that finds them, thrusts his paw into one of these holes, in order to get at the kernel; and the people, who are prepared for this circumstance, run up without delay, and seize him before he can disengage himself.

The preacher is the largest of all the American monkeys, being about the size of a fox : great numbers of them inhabit the woods of Brazil and Guiana. They frequently assemble in companies, and placing themselves in a kind of regular order, one of them first begins with a loud tone, which may be heard to a great distance: the rest soon join in full chorus, the most discordant and terrible that can be conceived. On a sudden, they all stop but the first, who closes the assembly with a solo. They live in trees, and leap from bough to bough with surprising agility, catching hold with their hands and tails as they spring from one branch to another; and maintain their grasp so firmly, that, even when shot, they remain fixed till they die.

Serpents are the great enemies to this active tribe, and their agility is a more powerful defence than 
a coat of mail ; for so conscious are they of its advantages, that some of them will leap backwards and forwards over the snakes, when they are reposing, without discovering the least sign of fear.

Stedman, who wrote an account of Surinam, minutely describes the gambols of the squirrel monkey, called by the natives keesee-keesee, an elegant little animal about the size of a rabbit. He saw numbers of them daily passing along the sides of the river, skipping from tree to tree, regularly following each other, like a little army, with their young ones at their backs, which have no unapt resemblance to knapsacks. The leader walks to the extremity of a bough, from which it springs to the end of an opposite one, belonging to the next tree, often at a most astonishing distance, and with such wonderful activity and precision that it nevers misses its aim : the others, one by one, and even the females with their little ones at their backs, which stick fast to the mother, follow their guide, and make the same leap, with equal certainty and ease.

This leads me to mention the extreme affection of the females for their young: they suckle, caress, and cleanse them of the vermin that harbour in their fur; then, crouching on their hams, observe their gambols with each other with great delight. Whilst the little ones are at play, wrestling, throwing each 
other down, or running after each other, if the dam perceives one of them malicious or untoward, she springs upon it, and seizing it by the tail with one paw, corrects it severely with the other. Sometimes the delinquent will try to escape; but when got out of reach, as if waiting till its mother's anger had subsided, returns gently, in a wheedling, caressing manner, to avert her displeasure. Sometimes they are all obedient to the first cry she makes as a signal of command, and will follow her if she goes a gentle pace; but if she has occasion to move swiftly, they mount upon her back, or cling to the fore part of her body. The female, thus loaded, will perform extraordinary feats of agility; and when tired of her burden, will rub against a tree till the little ones are obliged to descend, when the male takes them up in his turn.

The monkey tribe in America differs materially from those of the other quarters of the globe, in having neither cheek-pouches, nor callosities, or hardness, on the buttocks. They are divided into two genera, called Sapajous and Sagoins, which are distinguished from each other by characters peculiar to each. The tail of the sapajou is flexible, having the under part covered, generally, with a smooth, naked skin. The animal can coil it up or extend it at pleasure; suspend itself by its extremity from the 
branches of trees; or use it as a hand, to take hold of any thing it wants. The tail of the sagoin seems adapted to different purposes; being longer than those of the sapajous, straight, flaceid, and entirely covered with hair. 


\section{LETTER XXVIII.}

FROM CAROLINE TO EMILY.

MY DEAREST EMILY,

You who take so great an interest in every thing that relates to sporting should have been with us yesterday. We went to visit a salmon fishery, but a water-dog entertained us more than the capture of the fish. As soon as he perceived the men were preparing to cast the net, he instantly ran down the river of his own accord, and took his post in the middle of it on some shallows, where he could run or swim as occasion required; and in this position he placed himself with all the eagerness and attention so strongly marked in a pointer-dog who sets his game. For some time, I was at a loss to comprehend his design, but the event soon satisfied me, and completely justified the prudence of the animal; for the fish, when they feel the net, always endeavour to make directly out to sea. Accordingly, one of the salmon escaping from the net, rushed down the stream with great velocity towards the ford, where the dog stood to receive him at an advantage. A very diverting chase now commenced, in which, from the shallow- 
ness of the water, we could discern the whole track of the fish, with all its rapid turnings and windings. After a smart pursuit, the dog found himself left considerably behind, in consequence of the water deepening, by which he had been reduced to the necessity of swimming; but, instead of following this desperate game any longer, he readily gave it over, and ran with all his speed directly down the river, till he was sure of being again to seaward of the salmon, where he took post as before, in his pointer's attitude. Here the fish met him a second time, and a fresh pursuit ensued, in which, after various attempts, the salmon at last made its way out to the sea, notwithstanding all the ingenious and vigorous exertions of its pursuer. Though, on this occasion, the dog was unsuccessful, the fisherman assured us that it was no unusual thing for him to run down his game, and that honest Shag was of very great service to them, by turning the salmon towards the net.*

We did not order our horses till the cool of the evening; and having sufficient time before us, we suffered them to jog on at their own pace, that we might enjoy an extensive view of the ocean, rendered peculiarly majestic by the luminous appearance of its

* These circumstances are borrowed from Hamilton's Letters concerning the Coast of Antrim, and happened on the river Rush. 
waves. It seemed absolutely on fire: if you have never seen this beautiful phenomenon, I will give you a lively description of it, in the words of Crabbe:

"See, as they float along, th' entangled weeds Slowly approach, upborne on bladdery beads : Wait till they land, and you shall then behold The fiery sparks those tangled fronds infold, Myriads of living points; the unaided eye Can but the fire, and not the form, descry. And now your view upon the ocean turn, And there the splendour of the waves discern. Cast but a stone, or strike them with an oar, And you shall flames within the deep explore; Or scoop the stream phosphoric as you stand, And the cold flame shall flash along your hand; When, lost in wonder, you shall walk and gaze On weeds that sparkle, and on waves that blaze."

Some assert that these brilliant flashes of phosphoric light, that sometimes fringe every ware that rolls towards the shore, are produced by vast quantities of putrid matter, formed by the remains of dead fish; others, with more probability, as I think, attribute this splendid appearance to luminous insects. Leaving the solution of this interesting question to philosophers, I shall close my letter with an instance of gratitude and attachment in an elephant, that Mr. Palmer has read, but he cannot recollect the authority on which it rests, with the hope that it will excite Mr. Hervey to supply us with some more aneedotes of that intelli- 
gent animal. A troop of elephants were accustomed to pass a green-stall in their way to water. The woman who kept the stall took a fancy to one of these beasts, and frequently regaled her favourite with refuse greens and fruit, which attached him to her. It happened one day that they overturned her stall, and, in her haste to preserve her goods, she forgot her little son, who, by this neglect, was exposed to danger. The elephant perceived the child's situation, took it up with his proboscis, and carefully placed it in safety on a shed near at hand.

How superior in gratitude was this elephant to many of the human race! Of all the defects of disposition, ingratitude seems the most hateful and depraved: it argues a heart insensible to the best propensities of our nature. That neither of us may ever feel its sting, is the sincere wish of your

Caroline. 


\title{
LETTER XXIX.
}

\author{
FROM EMILY TO CAROLINE.
}

\section{MY DEAR CAROLINE,}

Mr. Hervey accepts your challenge, as he thinks that the opportunities he has had of observing animals wholly out of our reach will enable him to furnish you frequently with both amusement and information.

In his opinion,* the sense of smell, in some animals, seems to be connected with certain mental sympathies; as those of hearing and sight are, in all that possess them in any high degree. It has been observed that dogs, though entirely unacquainted with lions, will tremble and shudder at their roar; and an elephant that has never seen a tiger will, in the same manner, show the strongest symptoms of horror and affright at the smell of it. The late Lord Clive exhibited a combat between two of these animals at Calcutta; but the scent of the tiger had such

* These sentiments, and this relation, are extracted from Mr. Knight's elegant Analysis of Taste. 
an effect upon the elephant, that nothing could either force or allure him to go along the road where the cage in which it was enclosed had passed, till a gallon of arrack was given him, when, his horror suddenly turning into fury, he broke down the paling to get at his enemy, and killed him without difficulty.

The excessive eagerness which dogs express in smelling their game seems to Mr. Hervey to be but little connected with the appetite for food, and wholly independent of any preconceived ideas of the objects of their pursuit being fit for it: hence, several kinds of them will not eat the game which they pursue with such wild impetuosity, and of which the scent appears to animate them to ecstasy, far, he thinks, beyond what the mere desire of food could excite. But I cannot help doubting whether domestication has not perverted that sense, originally given them as a means of directing them to their natural prey, to a different purpose. As a confirmation of his theory, he adds, that where blood has been shed, particularly that of their own species, oxen will assemble, and, upon smelling it, roar and bellow, and show the most manifest symptoms of horror and distress. Yet these symptoms could not arise from any associated ideas of danger or death, since they appear in them that never had any opportunities of acquiring such ideas. They must, therefore, be instinctive, like many 
other antipathies and propensities, implanted by the hand of Providence as natural guards against danger, or impulses to find nourishment, by these sensations operating upon the passions and mental affections more immediately than it is found to do in the human species, which, enjoying the privilege of reason, stands less in need of such a monitor. Can any thing be more beautiful than such a system !-a provision for every thing necessary, but nothing redundant. The further I examine the capacities and propensities of animals, the more I admire the harmony of their endowments; including their dispositions and outward form, with the necessities peculiar to each. Their mouths, their eyes, their instruments of offence and defence-their forces, habits, and inclinations, are so nicely adapted to the food upon which they are to subsist, the enemies they are to attack or resist, the climate or situation they are to inhabit, that we may clearly see that this curious provision is not contrived for mere existence, but for a high degree of enjoyment. Happiness, in various gradations, seems a universal gift, bestowed by the Creator on all his creatures: man is the only one who, by a misapplication of his talents, perverts the benevolent design, and converts happiness into misery.

But to return from these reflections to Mr. Hervey. He relates a very surprising instance of the power of 
man to subdue the most ferocious and bloodthirsty of all animals, the tiger. He says, that some of the Foukeers, or mendicant priests, in many parts of Bengal, keep tigers in a state of domestication. $\mathrm{He}$ saw one near Colgony, that appeared under subjection to the Foukeer. This priest lived in a small hut, in the midst of a wilderness infested with tigers. The hut stood on a hill, overlooking the flat country on the opposite side of the Ganges. The Foukeer used to walk almost daily to the town, accompanied by the tiger, which seemed to create no alarm amongst the inhabitants, who had perfect confidence in the command the priest had over him.* But Mr. Hervey could not discover by what means this influence was obtained, as it was clearly the interest of the crafty priest to keep his art a secret, that he might retain the veneration of the people, who, doubtless, attributed his power over savage beasts to his sanctity. It could not proceed from attachment to one person, so beautifully displayed in many species of animals, particularly the elephant and the dog; because none but these priests are ever able to tame the fierceness of the tiger, or convert its cruel temper into any thing like friendship, though taken ever so young. It is, therefore, a sort of phenomenon for which Europeans cannot account. The tiger is a beautiful creature; but,

* Williamson's Oriental Field Sports. 
like the wasp, whose colours are similar, it bears the marks of malignity in its outward appearance, which serve to deter the spectator from any further acquaintance than a very distant view. Whilst we admire, we dread; and never desire to admit him as an inmate, but in the character of a slave, or a captive confined in a dungeon. How different is the powerful, half-reasoning elephant!-he is so useful, intelligent, and amiable, that he is treated with the kindness due to a valuable friend, which he returns with a fidelity and gratitude worthy of man himself. Take the following story as an instance of these qualities.

An elephant, which had been kept tame for some years, got loose during a stormy night, and rambled into his native jungles. Four years had nearly elapsed, when a large drove of these animals were trapped into an enclosure called a keddah. It happened that the keeper of the stray elephant was one amongst many that ascended the barricade of timber by which the keddah was surrounded, to inspect the prize they had taken. This man fancied he saw one amongst the new-caught elephants, that bore such a resemblance to his former charge, that he could not help suspecting that he had found his long-lost favourite. His comrades laughed at the idea, but no ridicule could deter him from calling it by the name of his 
old acquaintance; when, to the surprise of all present, the faithful creature acknowledged her former master, obeyed his call, and came towards him; which so overjoyed the man, that, forgetful of danger, he got over the barrier, and the elephant, as if feeling a reciprocal pleasure, lay down for his master to mount. The mohout joyfully bestrode his neck, and, with an insulting air, rode him to his pickets.*

Mr. Hervey having occasion to purchase an elephant, was offered a most majestic one, in point of size, at a very low price; but he declined the bargain, on account of a wound the creature had received in the trunk, from the cruel rashness of its keeper, by which it was greatly disfigured, and entirely disabled from the functions that member usually performs. It hung down, as if incapable of motion, and had lost the power of suction, or of grasping; consequently, the poor elephant was deprived of the power of procuring his own subsistence, and was wholly dependent on the attention of others. In this pitiable situation, one of its own species, a male elephant, sympathised in its distress, compassionated its sufferings, and constantly prepared for it bunches of grass, fresh leaves, \&c. and put them into its mouth. $\uparrow$

Can any thing be more amiable than this conduct,

* Williamson's Oriental Field Sports. † Ibid. 
or more similar to an act of reason? for the mere instincts of elephants could not teach them to discern the consequences of their companion's misfortune. Rats are said to show a degree of pity and sagacity nearly equal, in case of one of their community becoming blind: they have been seen to lead the blind rat to drink, by placing a straw in its mouth, and a rat at each end of it guiding their companion to the water.

The sagacity of elephants, it seems, is sometimes employed to seduce, as well as to assist those of their own kind. The females, when properly disciplined, are frequently employed by the mohouts, or keepers, to entrap the wild males; a task that they perform with the address, dexterity, and allurements of a Dalilah. After having completely attracted their admirer, who, like Samson, seems a willing slave, the sly deceiver contrives to amuse and divert the attention of her innamorato, whilst the mohout cautiously creeps, at the risk of his life, between them, and secures his prize, by confining his legs with strong fetters to a tree. Nothing can exceed the rage and resentment of the males when they discover the stratagem: their love is turned into the bitterest hatred. They sometimes break loose, and destroy both the mohout and his assistant, whom they seem to perceive was conscious of the delusion. They pursue her with 
fury, and beat her to death with their trunks. If she can outstrip her pursuer, she returns to her owner, and is ready for another adventure, whenever he chooses to employ her:*

I am, with renewed assurances of sincere attachment, your

\section{EMILY.}

* Williamson's Oriental Field Sports. 


\title{
LETTER XXX.
}

\author{
FROM CAROLINE TO EMILY.
}

\section{MY DEAR EMILY,}

FEw are better qualified to define what happiness is, than Mrs. Saville; because she enjoys as large a share of it as can fall to the lot of a mortal. The retrospect of her past life, and the animating hope of that which is to come, shed a constant cheerfulness over her mind, that diffuses itself in benevolence towards others, and is visible in all her actions. The dutiful affection of her daughter, the attachment of her friends, the fidelity of her servant, the love of her neighbours, are the possessions on which she sets the highest value, and secures to herself by her own conduct. A woman with such a taste has no occasion for wealth, because she is satisfied with those reasonable gratifications, which, though valuable, are not costly. Do not suppose that she is of a gloomy, reserved disposition : she is fond of society, and, by the vivacity and interest of her remarks, forms the chief ornament of that which she frequents. One of her pure pleasures is the assembling of a select circle 
of friends, amongst whom she never appears to take the lead, though, by the subjects she introduces, and her address in drawing forth the talents of others, she mostly contrives to give a useful turn to the conversation, and direct it to that which is at once agreeable and valuable. You can scarcely imagine the cheerfulness and harmony that prevail in these little parties; but last night our spirits were greatly damped by a gentleman who was in Ireland during the rebellion, the horrors of which, so disgraceful to both sides, he detailed with a minuteness that brought many shocking scenes before us. Amongst other anecdotes, he told a story so extraordinary, that Mr. Palmer, who is a most rigid exacter of the truth in relating a narration, required his authority. Upon this, he referred to his pocket-book, and found that he had taken it from page 168 of Gordon's History of the Rebellion. I give it you as he read it from his notes.

" The recovery of Charles Davis of Enniscorthy, a glazier, was remarkable. After having remained four days concealed in the sink of a privy, during which time he had no other sustenance than the raw body of a cock, which had, by accident, alighted on the seat, he fled from this loathsome abode; but was taken at some distance from the town, brought to Vinegar Hill, shot through the body and one of his arms, violently struck in several parts of the head with 
thrusts of a pike, which, however, penetrated not into the brain, and thrown into a grave on his back, with a heap of earth and stones over him. His faithful dog having scraped away the covering from his face, and cleansed it by licking the blood, he returned to life, after an interment of twelve hours, dreaming that pikemen were going to stab him, and pronouncing the name of Father Roche, by whose interference he hoped to be released. Some superstitious persons hearing the name, and imagining the man to have been revivified by the favour of Heaven, in order that he might receive salvation from the priest, by becoming a $\mathrm{Ca}$ tholic before his final departure, took him from the grave to a house, and treated him with such kind attention that he recovered, and is now living in apparently perfect health."

"The man's restoration, after such treatment, would be absolutely beyond belief," said Mr. Palmer, "were it not attested by an author of credit, who lives within a few miles of him, and seems to speak from personal knowledge. The circumstance of the dog is the least surprising part of the story, as there have been well-authenticated instances of similar fidelity." A subject once set agoing, acts like the electric spark, and excites general sympathy. Thus, one story produces another. We were now entertained with the following affecting narrative. "In 1789, 
when preparations were making at St. Paul's for the reception of his Majesty, a favourite bitch followed its master up the dark stairs of the dome. Here, all at once, it was missing, and calling and whistling were to no purpose. Nine weeks after this, all but two days, some glaziers were at work in the cathedral, and heard, amongst the timbers which support the dome, a faint noise. Thinking it might be some unfortunate human being, they tied a rope round a boy, and let him down near the place whence the sound came. At the bottom he found a dog lying on its side, the skeleton of another dog, and an old shoe half eaten. The humanity of the boy led him to rescue the animal from its miserable situation; and it was accordingly drawn up, much emaciated, and scarcely able to stand. The workmen placed it in the porch of the church to die or live, as it might happen. This was about ten o'clock in the morning. Some time after, the dog was seen endeavouring to cross the street at the top of Ludgate Hill; but its weakness was so great, that, unsupported by a wall, it could not accomplish it. The miserable appearance of the dog again excited the compassion of a boy, who carried it over: By the aid of the houses it was enabled to get to Fleet Market, and over two or three narrow crossings, in its way to Holborn Bridge; and about eight o'clock in the evening it reached its master's house in 
Red Lion Street, Holbom, and laid itself down on the steps, having been ten hours on its journey from St. Paul's to that place. The dog was so much altered, the eyes being so sunk in the head as to be scarcely discernible, that the master would not at first encourage his old faithful companion, who, when lost, was supposed to weigh $201 \mathrm{lbs}$. and now only weighed 3lbs, 140z. The first indication it gave of knowing its master, was by wagging the tail when he mentioned the name of Phillis. For a long time it was unable to eat or drink, and it was kept alive by the sustenance it received from its mistress, who used to feed it with a tea-spoon, and by her care recovered it."*

The length of time this poor creature must have subsisted without food is surprising; and the efforts it made in such an emaciated condition to reach its master's house, that it might die at his feet, is a striking instance of that unshaken attachment that the canine race show for their protectors. The friendship of a dog for his master is seldom equalled by that of one man for another. How many friends shrink from their professions in the hour of danger, poverty, and disgrace! - but when his services are the most wanted, the faithful dog never flinches from his duty, and numerous are the examples of their sacrificing their own lives in the defence of those to whom they are attached.

* Daniel's Rural Sports, vol. i. p. 28. 
Mr. Clarke, who has published his travels through Russia and the Crimea, had a most affectionate little pug-dog, that accompanied him through his long journey, enduring all the vicissitudes of heat, cold, and fatigue, with the most perfect good-humour. "Though naturally afraid of the water," says he, " and always averse from entering it, he crossed all the rivers and lakes of Lapland, Sweden, and Norway, after his masters, and accompanied them three years in different climates, yet detesting bodily exercise: and ultimately performed a journey on foot, keeping up with horses, from Athens, through all Greece, Macedonia, and Thrace; making the tour of the Archipelago, to Constantinople; and thence, in the same manner, through Bulgaria and Wallachia, to Bucharest!" How I should have valued an animal that had followed me so far with such unwearied fidelity! and though he could not articulate his feelings, I should be at no loss to understand his mute eloquence, and would repay it with every mark of favour a dog could enjoy. He should attend me in my walks, partake of my meals, and repose before my fire. Rest and plenty should be his portion for the remainder of his days.

As I was running over some new books, lately sent from London to a gentleman in our neighbourhood, I met with the following passage, which records the 
services of the dog so appropriately, that I shall insert it.

"The faithful dog, the natural friend of man, The unequal federation first began; Aided the hunter in his savage toil, And grateful took the refuse of the spoil; Watch'd round his bed at sleep's unguarded hour, And drove the hungry tiger from his bow'r; In deeds of death and danger led the way, And bled, unconquer'd, in the doubtful fray ; Still fought, though wounded, by his master's side, And, pleas'd to save him, grasp'd his prey, and died. As more the bounds of social rights expand, And peaceful herds submit to man's command, Still, as a faithful minister, he shares The shepherd's labours, and divides his cares ; Prowls round the hill or to the allotted plains, The climbing goat or wandering sheep restrains: With nice discriminating nose inhales The passing odours in the tainted gales ; The wolf's approach o'er distant mountains hears, And clamorous barks, and points his list'ning ears, And nearer still, as the fell savage howls, Bristles his wavy back, and fierce defiance growls." *

Rachel has a most faithful dog, of the Newfoundland breed, that always guards us in our walks; and so courageous is he, that we fear no enemy when he is with us. I see him now from the window, wagging his tail, and showing other marks of joy,

* Knight, on the Progress of Civil Society. 
which lead me to suppose that he sees Rachel with her bonnet on, waiting for me to set out; I must therefore conclude, with many assurances that my fidelity and affection to you equal those of any of the four-legged heroes I have been commemorating.

Caroline. 


\section{LETTER XXXI.}

FROM EMILY TO CAROLINE.

\section{DEAR CAROLINE,}

Mr pen has lain dormant for some time, from my engagements with Mr. and Mrs. Hervey. I have been staying several weeks with them, and am greatly pleased with Charlotte's behaviour as a wife. She is exceedingly attached, and evidently endeavours to take delight in his pursuits, by assimilating her taste to his. Their house is charmingly situated on the banks of a small river, that runs through the grounds; and though it is neither large nor magnificent, it is elegantly neat, and possesses every convenience that can promote order and comfort. They live in a liberal manner, and keep the best company in their neighbourhood; so that they enjoy a sufficient mixture of society and retirement, to give a zest to each other. When we are alone, we generally enjoy our evenings in strolling about the plantations; and as Mr. Hervey is a naturalist, the most minute object furnishes him with a theme 
to entertain us, especially as he has visited so many climates, that he often illustrates his subjects by an account of what he has seen in other countries.

In one of our rambles along the edge of the river, I perceived something at the bottom of the water, which had the appearance of a flower. I remarked it to my companions. Observing it attentively, we found that it consisted of a circular assemblage of minnows : their heads all met in a centre, and their tails diverging at equal distances, and being elevated above their heads, gave them the appearance of a flower half blown. One was longer than the rest, and as often as a straggler came in sight, he quitted his place to pursue him; and having driven him away, he returned to it again, no other minnow offering to take it in his absence. This we saw him do several times. The object that had attracted them all, was a dead minnow, which they seemed to be devouring.* How strange! that they should feast on the dead body of one of their own species, and that so much order should be observed in the ceremony. Fishes appear to have less intelligence than quadrupeds or birds; at least, their facility of communication with us is so much less, that we cannot so readily perceive the drift of their actions, as those of the creatures which inhabit the

* Hayley's Life of Cowper, Letter 60th. 
same element as ourselves. Quadrupeds certainly have the superiority above other animals, man excepted, in the scale of intelligence; yet the elegant form, beautiful plumage, and interesting manners of the various species of birds, have made me so partial to them, that I collect with pleasure every anecdote I can obtain of their amiable instincts. Two or three present themselves to my recollection at this moment, which may probably amuse you. The first is extracted from the Buckinghamshire Herald, for Saturday, June 1st, 1793, and is as follows:

"Glasgow, May 23.

" In a block, or pulley, near the head of the mast of a gabert now lying at the Bromielaw, there is a chaffinch's nest and four eggs. The nest was built while the vessel lay at Greenock, and was followed hither by both birds. Though the block is occasionally lowered for the inspection of the curious, the birds have not forsaken the nest. The cock, however, visits the nest but seldom, while the hen never leaves it but when she descends to the hulk for food."

What a remarkable instance of maternal love, so deeply implanted by the Great Creator, for the preser- 
vation of the infant brood! The poet Cowper was so pleased with the circumstance, that he commemorated it in the following stanzas.

\section{A TALE.}

IN Scotland's realm, where trees are few,

Nor even shrubs abound;

But where, however bleak the view,

Some better things are found.

For husband there, and wife, may boast

Their union undefil'd ;

And false ones are as rare, almost,

As hedge-rows in the wild.

In Scotland's realm, forlorn and bare,

This hist'ry chanc'd of late-

This hist'ry of a wedded pair,

A chaffinch and his mate.

The spring drew near, each felt a breast

With genial instinct fill'd ;

They pair'd, and only wish'd a nest,

But found not where to build.

The heaths uncover'd, and the moors,

Except with snow and sleet !

Sea-beaten rocks, and naked shores,

Could yield them no retreat. 
Long time a breeding-place they sought, Till both grew vex'd and tir'd ; At length a ship arriving, brought The good so long desir'd.

A ship !-Could such a restless thing Afford them place to rest?

Or was the merchant charg'd to bring The homeless birds a nest ?

Hush ! silent hearers profit most !

This racer of the sea

Prov'd kinder to them than the coast, It serv'd them with a tree.

But such a tree!' twas shaven dealThe tree they call a mast; And had a hollow with a wheel, Through which the tackle pass'd.

Within that cavity aloft, Their roofless home they fixt ; Form'd with materials neat and soft, Bents, wool, and feathers mixt.

Four iv'ry eggs soon pave the floor,

With russet speck bedight;

The vessel weighs-forsakes the shore, And lessens to the sight.

The mother bird is gone to sea, As she had chang'd her kind; But goes the mate?-Far wiser, he Is doubtless left behind. 
No!-Soon as from ashore he saw

The winged mansion move;

He flew to reach it, by a law

of never-failing love.

Then, perching at his consort's side,

Was briskly borne along;

The billows and the blast defied,

And cheer'd her with a song.

The seaman, with sincere delight, His feather'd shipmate eyes; Scarce less exulting in the sight, Than when he tows a prize.

For seamen much believe in signs, And from a chance so new, Each some approaching good divines, And may his hopes be true!

Hail! honour'd land! a desert, where

Not even birds can hide;

Yet parent of this loving pair,

Whom nothing could divide.

And ye, who rather than resign

Your matrimonial plan,

Were not afraid to plough the brine,

In company with man :

To whose lean country, much disdain

We English often show;

Yet from a richer, nothing gain,

But wantonness and woe. 
Be it your fortune, year by year,

The same resource to prove;

And may ye, sometimes landing here,

Instruct us how to love !

The accommodation of these poor birds to necessity is a striking example of deviation from instinct, under particular circumstances. I will now relate a curious instance of pure instinct, in which two birds act in concert, and seem necessary to each other, which Mr. Hervey has observed in very distant parts of the world. When he was in Russia, he obtained a curious account of the pelican's mode of fishing, with the assistance of the cormorant. The pelican extends its wings, and troubles the water, while the cormorant, diving to the bottom, drives the fish to the surface; and the pelican, continuing the motion of its wings advances towards the shore, where the fish are taken among the shallows: afterwards, the cormorant, without further ceremony, helps himself out of the pelican's beak.*

To this surprising intelligence between these two birds he easily gave credit, because he had observed something very similar in the West Indies between the sea-pelican and a small sea-gull. As he was sailing near the island of Tortola, he repeat-

* Clark's Travels in Russia, \&c. 
edly saw sea-pelicans flying over the waves, and plunging into them, as if they had been shot, to catch small fish; and it generally happened, that before the pelican drew his head out of the water, a small sea-gull perched upon its back, and as soon as the fish appeared in sight, snatched it out of the pelican's mouth, and flew away with the spoil.*

The care of the pelican for the preservation of her eggs is remarkable. They construct their nests of rushes, and line the interior with moss, or any soft herb. These nests are found on the small islets of rivers, and places where moss is in plenty. They lay two white eggs, about the size of those of the swan, and employ the same time in hatching. If disturbed while sitting, they hide their eggs in the water, and take them out afterwards with their bill, when they believe the danger removed. They live altogether on fish, and consume a prodigious quantity. $\uparrow$

Dr. Darwin confirms the accounts, already related, of one sea-fowl taking fish from another, by stating, from a traveller named Osbeck, that the man-of-war bird, a species of pelican that is not formed to catch

* Sir Henry Martin, Bart. favoured me with this fact, which he saw as above.

+ Clark's 'Travels. 
fish, is supported by robbing others, in the manner before described, who are better qualified for the task.

Adanson, in his voyage to Senegal, relates, that on the river Niger, in the way to the island Griel, he saw a great number of pelicans, or wide-throats. They moved with great state, like swans, upon the water, and are the largest bird next to the ostrich. The bill of one he killed was upwards of a foot and a half long, and the bag fastened underneath it held twenty-two pints of water. They swim in flocks, and form a large circle, which they contract afterwards, driving the fish before them with their legs. When they have collected a sufficient quantity of fish within this space, they plunge their bill wide open into the water, and shut it again with great quickness; laying up, by this means, a store of fish in their capacious bag, till they have an opportunity of eating it on shore. Here I ought to remark, that this account may not be applicable to every species of pelican, as there are several kinds, that differ from each other in size and habits.

Clavigero relates, in his history of Mexico, that it is a practice amongst the natives to catch a pelican, and, after breaking its wing, to tie it to a tree, where it is amply supplied with fish by other wild pelicans, who humanely feed their wounded companion. By 
the time they suppose that his bag is full, these barbarians return to the place, and unmercifully rob him of his treasure.

The spirit of plunder that appears in the cormorant and sea-gull was observed by Doctor Darwin in two crows also, which followed a hawk till he had caught his prey, and then compelled him to share his prize with them.

The same author relates a most ingenious artifice, used by more than a hundred crows, on the northern coast of Ireland, which marks contrivance rather than mere instinct. These crows were preying upon muscles, a kind of food by no means usual with them: each crow took up a muscle into the air, twenty or forty yards high, and let it fall on the stones with such force, that the shell was broken, and the helpless fish became an easy prey.

In the superficial view of nature that falls to the common lot, numberless are the instances of wisdom and goodness that are found in the means with which each creature is furnished for its own support and preservation-I may say, for its gratification; for there is nothing that has life, so minute or so mean, that is not intended for a degree of happiness adapted to its power of enjoyment. The poet says, "To enjoy, is to obey." It seems to be a universal 
law, that, as far as respects rational beings, cannot be perfected without interruptions, till we arrive at that state when there shall be no more vice, sickness, or sorrow-when friends shall never part, or prove faithless.

Adieu, my Caroline.

EMILY. 
ADVANTAGES OF STUDYING NATURE.

\section{LETTER XXXII.}

FROM CAROLINE TO EMILY.

MY DEAR FRIEND,

THE taste for natural history, that we have both acquired from a residence in the country, seems to have great advantages. To say nothing of the endless variety of amusement it has afforded us, without any mixture of remorse, or misapplication of time, it has led us to trace the wisdom of the Great Creator in all his works that have fallen under our observation ; for who can observe the harmony between construction and habit in the animal world, and not adore the "Hand Divine" that formed them? The strength and weapons of each are exactly proportioned to the enemies with which it has to contend: if weak and defenceless, their instincts lead them to avoid danger, by concealment or stratagem. Sometimes the colour of their coats forms their security : insects, and probably many birds, are of nearly the same hue as the places they inhabit. The sober plumage of green-finches and linnets nearly accords with the green leaves and brown branches of trees. Several of the tribes of water-fowl are of a light grey 
or ash-colour, not very dissimilar to that of the sea; and it is well known, that the Siberian hare, and other inhabitants of northern regions, turn white on the approach of winter, when the ground, for months, is covered with snow. Thus, the same end is attained by different means. If the outside form and colour are thus nicely adapted to the accommodation of the animal, the inside is no less so: its powers of digestion are suited to the food it is to consume: each one has its peculiarities, that harmonize with its own mode of life, and with no other. The same study leads us still further: it instructs us, that not their bodies only, but their dispositions, inclinations, and degree of intelligence, correspond exactly with the situation each creature is to fill, and that more or less sagacity in any of them, so far from increasing their happiness, would disqualify them from performing their respective tasks. The instincts of each tribe, of whatever class, are so nicely contrived, as to promote, in the best possible manner, its preservation and enjoyment, and demonstrate most powerfully the design of an all-wise and benefieent Creator, who delights to diffuse happiness to innumerable orders of beings; even to the most minute and, in our eye, inferior links of that stupendous chain that reaches from celestial intelligences to the animalculæ that cannot be perceived without a microscope. The mental powers appear to diminisin, in a sort of scale 
proportioned to the rank of the creature that is endowed with them. Man, partaking of the animal nature, though endowed with the noble faculty of reason, is first subject to the influence of instinct. Quadrupeds, after man, are the most intelligent of the lower world, and the most capable of deviating from the instinctive impulse; as is evinced by innumerable well-attested instances of sagacity, that seem to be the result of reflection and experience in the horse, the dog, and the half-reasoning elephant. One of these occurs to my recollection, and supports my theory so completely, that I must relate it.

The late Hon. General Murray, governor of Quebec, a short time before his death, when become feeble, walking out one morning in his grounds at Beauport, near Hastings, attended only by a little spaniel, fell, and was unable to rise. The dog immediately ran into the house, barked, and pulled the servants by their clothes ; but failing to gain their attention, he ran about till he found a labourer, whom he succeeded in leading to the spot where the general still lay, unable to rise.* Instinct alone could never teach him to seek assistance in this manner, to raise up his fallen master.

Birds seem to hold the next rank to quadrupeds; fishes to birds; and lastly, the beautiful, active, and diminutive race of insects, appear most entirely under

* Mrs. Davies Giddy. 
the guidance of instinct ; but though, perhaps, wholly devoid of any other principle of action, their structure and habits well deserve the attention of the inquisitive mind, which may perceive, in these little creatures, the same wise adaptation of means to a certain design, as in the animals of greater magnitude and more enlarged capacities. Some peculiarities are common to them all: none have less than six feet; some, many more : they are always furnished with antennæ, which are distinguished from horns by being jointed and flexible, and are supposed to be the organs of some sense of which we are ignorant. The head has neither brain, ears, nor nostrils : most of them have two eyes; spiders have eight. Leuwenhoek discovered eight hundred lenses in a fly; and Pugett, seventeen thousand three hundred and twenty-five, in the cornea of a butterfly. They are furnished with pores on the sides of their bodies, through which they breathe; yet, from microscopic examination, some of them are found to possess several lungs and several hearts. Silkworms have a chain of hearts, as may be plainly seen when they become almost transparent, and are near spinning. Such insects as live in communities, like bees, ants, \&c. are of three sexes. Each family of bees has one female only, called the queen, who is the mother of the whole hive; many males; and a very great number of neuters, or working bees, which provide all 
necessaries for the young brood, by collecting honey and wax, building up the cells, watching the approach of an enemy, \&c. The outside covering of the bodies of insects is often hard, and supplies the place of bones, of which, internally, they are destitute. Another circumstance peculiar to insects is, a change from one place to another: from the egg is hatched the caterpillar or maggot, which is transformed into the chrysalis, from whence proceeds the fly, or perfect insect.

As insects are endowed with the various powers of creeping, flying, and swimming, the air, earth, and water teem with them: and so minute and numerous are they, that scarcely any place is free from them. Trees, shrubs, leaves, and flowers, are the favourite haunts of many kinds ; rocks, sands, rivers, lakes, and standing pools, of others; whilst different tribes being appointed to clear our globe from all offensive substances, resort to houses, dark cellars, damp pits, rotten wood, subterranean passages, putrid carcasses, and the dung of animals. These little creatures, so feeble, so diminutive, apparently so insignificant, are, nevertheless, powerful agents to benefit or injure mankind. My ignorance will not suffer me to mention half their uses; but some of them serve for food, others for medicine; some are important in the arts, and especially to the dissecter. The great Ruysch surprised the anatomists of his day by the nicety of his preparations, 
which far excelled those of all his competitors. No one could imagine what means he used for this purpose, till he acknowledged that the flesh-maggot was the workman he employed, by suffering it to devour the fleshy parts. In their devastations, they have often destroyed the hopes of the husbandman, and threatened famine to a whole district. Locusts have been known to darken the air, and to devour every green thing, leaving destruction and terror behind them. The white ants in Africa and the West Indies are very formidable, both abroad and in the house, as they spare hardly any substance that comes in their way; wood, paper, \&c. are devoured with undistinguishing fury. Dr. Darwin remarks, that the small green insect that often covers the stems and leaves of plants, called the aphis, if its innumerable tribes were not thinned by, various rapacious enemies, would destroy every kind of regetable, and starve the whole human race. But, by the wise appointment of an all-discerning Providence, it is so ordered that a balance is preserved: one species serves as a check upon another, and maintains a due proportion.

The minuteness of insects, and the small recesses in which they conceal themselves, withdraw them from our notice, so that the habits of many of them are very imperfectly known; yet there are some particulars so curious and interesting, mentioned by $\mathrm{Mr}$. 
Palmer in a lecture on these little creatures, that I long to obtain further knowledge about them, and am beating every bush and shrub in search of cockchafers, caterpillars, flies, and moths. Could my former acquaintance see me thus employed, how they would ridicule my taste for pursuing such objects as they behold with disgust! But we see with different eyes. A spider would excite, in most of them, abhorrence, if not terror. Reason and habit have so overcome the prejudices of my infancy, that I can look at them, not only without apprehension, but with admiration. What can deserve attention more than a spider's web? How artful its construction! each web being adapted to the place it is to fill. This little artist strengthens those lines that are too weak, by joining others to the middle of them, which she attaches to distant objects. These nets serve two purposes : the first and most obvious is, that of entangling flies, the natural prey of the spider; the other, to supply the want of wings, and convey the insect from place to place. Field spiders being more exposed to the injuries of dews and tempests, construct their nets with more mathematical exactness than the house spiders: with such precision is instinct accommodated to circumstances.

Some spiders have a dwelling, or lodging-place, in the middle of the web, well contrived for warmth, security, or concealment. There is a large spider in 
South America, which forms nets of so strong a texture as to entangle small birds, particularly the humming-bird. In Jamaica, there is a species that digs a hole in the earth, obliquely downwards, about three inches in length, and one in width: this cavity the insect lines with a tough, thick web, which, when taken out, resembles a leathern purse. But what is a still greater defence, this house has a door with hinges, like the enclosure of an oyster or a muscle, which is opened and shut when any of the inhabitants go abroad or return home.

Many insects, if they are touched, defend themselves hy feigning death : they instantly roll themselves up, or shrink, as it were, from danger, and remain motionless a considerable time. The different species of gallinsects produce a nidus for their young; as, the thorny excrescences on briers, the oak-apples, the lumps on leaves of trees, and those on the backs of cows.

The strongest impulse, through all the insect tribes, after satisfying hunger and self-defence, is that of providing for their future progeny; but, as the existence of the mother, in many kinds, terminates long before the young are hatched, this care cannot be attributed to affection, but to an invariable law, impressed on every individual by the hand of the Creator, for the purpose of preserving the species. Ichneumons display extraordinary sagacity in the disposal of their 
eggs : they remove them many times in a day, either nearer to the surface of the ground, or deeper below it, according as the heat or moisture of the weather varies. One species of ichneumon fly digs a hole in the earth, and, after carrying two or three living caterpillars into it, deposits her eggs there, then nicely closes up the nest with leaves; providing, in this artful manner, as if she had foresight, warmth to hatch her young, and food for their sustenance when brought to life. Some ichneumons lay their eggs in the backs of caterpillars, where their maggot is nourished with that substance that is converted into the silk thread of which the future cocoon is formed.

Insects that go through several transformations often place their eggs where they may find food of a different nature from that which they themselves consume ; for example, butterflies lay their eggs on leaves, though they eat honey; but let it be remembered, that it is a caterpillar, and not a butterfly, that is to proceed from the egg. Instinct teaches animals to accommodate their habits to different climates. Sparrows, even in this country, are said to build their nests without a covering when placed under shelter, and with one when exposed to the weather. The small birds of Europe, if in those countries where monkeys abound, change the form of their nests to that of a long purse, suspended at the end of the bough of a 
tree, to secure their young from the attacks of that animal. In a part of Siam which is subject to inundations, the ants form their settlements on trees: no ants' nests are to be seen anywhere else.

Thus it appears that instinct is an unerring guide, teaching her pupils just as much as is necessary for them to know; and likewise an impartial one, for she bestows her gifts equally on all the individuals of the same species. How different from the genius and intelligence of the human race! amongst whom such minds as those of Newton, Locke, Columbus, \&c. exalt their possessors so much above their fellows, that they are like a superior race. But a few more remarkable instances of this impulse will render my letter more worthy your acceptance.

Wasps are said to eatch large spiders, and finding their long legs an impediment, cut them off, and afterwards carry their mutilated bodies that can no longer escape, to their young. Dr. Darwin relates, that he saw a wasp on a gravel-walk, that had caught a fly nearly as large as himself: he separated the tail and the head from that part of the body to which the wings were attached: after this operation, he took the bodypart in his paws, and rose about two feet from the ground. A gentle breeze wafting the wings of the fly, turned him round in the air, and he settled again with his prey upon the gravel. He then cut off with his mouth, first one of the wings, and then the other; 
after which he flew away with it, undisturbed by the wind.

The same author says, that the nymphæ of the water-moths of our rivers, which cover themselves with cases of straw, gravel, and shell, contrive to make their habitations nearly in equilibrium with the water. When too heavy, they enlarge their bulk with a bit of wood or straw; when too light, they add a bit of gravel. The instinctive faculty teaches them, without reasoning, to adjust the weight of their frail dwelling with that of an equal bulk of water. The case of the wasp and the fly seems less consistent with the uniformity of the operations of those insects.

Insects, in some instances, mistake their instincts. At a certain season of the year, the fire-flies in Jamaica are seen in the evenings in great abundance. When they settle on the ground, the bull-frog greedily devours them; which has probably suggested the idea of destroying those animals by throwing red-hot pieces of charcoal towards them in the dusk, when they leap at them, and hastily swallowing them, are destroyed. In like manner, the putrid smell of the stapelia, or carrion-flower, allures the large flesh-fly to deposit her eggs in its beautiful petals, where the young worms, when hatched, perish for want of nourishment.

Long-legs, moths, and many kinds of flies, mistake the light of a candle for the rays of the sun, and rush into the flame to their destruction. 
In the three last examples, the intention is perverted from accident; but it is the consequence of that invariable law bestowed for their preservation.

These are a few of the innumerable displays of Divine wisdom and goodness in the various classes of the minute tribes of insects; but they are sufficient to induce you to acquaint yourself with more; and my letter is already so long, that I shall only add, that I am, with unalterable friendship, yours,

Caroline. 


\section{LETTER XXXIII.}

\section{FROM EMILY TO CAROLINE.}

Believe, dear Caroline, that your last letter afforded me much entertainment, and has excited my curiosity to examine for myself into the wonders of the insect world. I have bought a microscope, and am already surprised at the beauty of many of those tiny creatures, that I have so often overlooked as ugly or insignificant. I would begin to make a collection of them, but I cannot resolve to put them to death merely for my pleasure. I abhor the idea of inflicting pain, or taking away life from any creature, wantonly; and it often astonishes me to see some people, otherwise humane, stamp upon a spider or a beetle without repugnance. Women are more tenderhearted than men; which may partly be attributed to a wise provision of nature, to qualify them for the maternal office. But they are also indebted to education : cruelty is discouraged in girls, as unamiable and discordant with their natural character; so that an affectation of great sensibility has, of late years, been very fashionable. Boys, on the contrary, from 
false notions of courage and spirit, are suffered to take birds' nests, to tyrannize over horses and dogs, \&c. till their feelings are blunted to a degree that influences their conduct the rest of their lives. This prevails most where there is least cultivation; consequently, we see animals treated with the most unfeeling barbarity by butchers, fishmongers, poulterers, draymen, cattle-drivers, \&c. But can we expect reformation, whilst those who should know better buy crimped fish, and deal with poulterers who pluck their fowls before they are dead? which is a common practice, because it is done with less trouble. The lesson of humanity to every thing that breathes should be taught from the very dawn of reason, and repeated on every occasion of enforcing it. Angling with worms, birds'-nesting, and spinning cockchafers, are, by the unthinking, overlooked in their children as the common amusements of their age; but they harden the heart, and sow the seeds of a cruel disposition, that is often exercised towards wives, children, and servants.

My warmth on this subject is probably increased by the severe discipline of a horse-breaker to a colt of my father's. I remonstrated day after day, but could gain no attention, or any other reply than "it was necessary to bring him to obedience." Mr. Craven happened to call at this time: I renewed the subject, 
hoping that he would unite with me in entreating compassion towards the poor colt. Instead of this, he said he did not know how it could be avoided, unless we were in possession of the secret of James Sullivan, who had the art of subduing the most ferocious horse in a very extraordinary manner. Seeing my curiosity was excited, he proceeded as follows:

"James Sullivan, madam, was a native of the county of Cork, and an awkward, ignorant rustic, of the lowest class, generally known by the appellation of the Whisperer, and his profession was horse-breaking. The credulity of the vulgar bestowed that epithet upon him, from an opinion that he communicated his wishes to the animal by means of a whisper; and the singularity of his method gave some colour to the superstitious belief. As far as the sphere of his control extended, the boast of veni, vidi, vici, was more justly claimed by James Sullivan, than by Cæsar, or even Bonaparte himself. How his art was acquired, or in what it consisted, is likely to remain for ever unknown, as he has lately left the world without divulging it. His son, who follows the same occupation, possesses but a small portion of the art, having either never learned its true secret, or being incapable of putting it in practice. The wonder of his skill consisted in the short time requisite to accomplish his design, which was performed in private, and without 
any apparent means of coercion. Every description of horse, or even mule, whether previously broke or unhandled, whatever their peculiar vices or ill habits might have been, submitted, without show of resistance, to the magical influence of his art, and, in the short space of half an hour, became gentle and tractable. The effect, though instantaneously produced, was generally durable. Though more submissive to him than to others, yet they seemed to have acquired a docility unknown before. Whien sent for to tame a vicious beast, he directed the stable, in which he and the object of the experiment were placed, to be shut, with orders not to open the door until a signal given. After a tête c̀ tête between him and the horse for about half an hour, during which little or no bustle was heard, the signal was made, and, upon opening the door, the horse was seen lying down, and the man by his side, playing familiarly with him, like a child with a puppy-dog. From that time he was found perfectly willing to submit to any discipline, however repugnant to his nature before. I once saw his skill tried on a horse which could never before be brought to stand for a smith to shoe him. The day after Sullivan's half-hour lecture, I went, not without some incredulity, to the smith's shop, with many other curious spectators, where we were eye-witnesses of the complete success of his art. This, 
too, had been a troop-horse; and it was supposed, not without reason, that, after regimental discipline had failed, no other would be found availing. I observed that the animal seemed afraid whenever Sullivan either spoke or looked at him: how that extraordinary ascendency could have been obtained, it is difficult to conjecture. In common cases, this mysterious preparation was unnecessary. $\mathrm{He}$ seemed to possess an instinctive power of inspiring awe, the result, perhaps, of a natural intrepidity, in which, I believe, a great part of his art consisted; though the circumstance of the tête à tête shows that, upon particular occasions, something more must have been. added to it. A faculty like this would, in other hands, have made a fortune, and great offers have been made to him for the exercise of his art abroad; but hunting, and attachment to his native soil, were his ruling passions. He lived at home, in the style most agreeable to his disposition, and nothing could induce him to quit Duhallow and the fox-hounds."*

When Mr. Craven had come to the termination of his story, my father, who is rather incredulous, cried out: "Well, Craven, there are many unaccountable

* Rev. Horatio Townsend's Survey of the County of Cork. This gentleman remarks, that though the above facts appear almost incredible, they are nevertheless indubitably true, and he was an eye-witness of their truth. P. 438. 
things that are true; but I would not have believed this, if you had not seen it yourself."

From Sullivan, and his wonderful powers, the conversation turned upon the sagacity of horses. In a wild state they live in troops, and when hunted by the Tartars, set watches to prevent being surprised, and have commanders, who direct and hasten their flight. In this country, in a domesticated state, when several horses travel in a line, the first always points his ears forward, and the last points his backward; whilst the intermediate ones appear to be quite careless in this respect, as if they trusted to the vigilance of their companions at each end of the line, to listen to any sound of danger, either behind or before. Is this instinct, or a preconcerted measure?

There are some parts of a horse which he cannot reach to rub when they itch, particularly about the shoulder, which he can neither bite with his teeth, nor scratch with his hind foot. When this part itches, he goes to another horse, and gently bites him in the part which he wishes to be bitten: a kind office that is immediately performed by his intelligent companion. An attentive observer of nature ${ }^{*}$ once remarked a young foal bite its mother for this purpose. The mare did not choose to drop the grass she had in her mouth, and, instead of biting it, merely rubbed her nose

* Dr. Darwin. 
against the foal's neck; from whence he inferred, that it was reflection, rather than instinct, that taught her to rub where she was bitten.

In the extensive moorlands of Staffordshire, the horses stamp upon the gorse furze with their fore feet, in order to break the points of their thorns, which renders it convenient to eat; whereas, in more fertile parts of the country, horses take no such precaution, from want of experience, as it appears,-but when they attempt to feed on this shrub, prick themselves till their mouths bleed.

Next to the elephant, I think the horse the most noble, generous, useful creature that man renders subservient to his will,- - though, perhaps, a Laplander would prefer the rein-deer, or an Arab the camel; but I am not so well acquainted with their dispositions, though I acknowledge their usefulness in their respective countries.

Of all domestic animals, swine are the least pleasing; yet Mr. Craven assures me that we are apt to regard them as stupid merely from the forbidding appearance of their exterior form, and their disagreeable habits of wallowing in the mire, and eating any kind of food without discrimination. He says that they have more intellect than is generally supposed: that nature has bestowed on them a sense of touch, as well as smell, at the end of the nose, which they use as 
we do our hands, both to root up the soil, and to examine any thing eatable that comes in their way. In our uncertain climate, experience teaches them to collect straw in their mouths, to make their nest when the wind blows cold, and to assemble their companions by repeated calls, to assist in the work, and add to their warmth by lying close together.

Mr. Craven finished his vindication of the swinish race by the following anecdote of an American sow. This animal passed her days in the woods, with a numerous litter of pigs; but returned regularly to the house in the evening, to share with her family a substantial supper. One of her pigs was, however, quietly slipt away to be roasted; in a day or two afterwards, another; and then a third. It would appear that this careful mother knew the number of her offspring, and missed those that were taken from her; for, after this, she came alone to her evening meal. This occurring repeatedly, she was watched coming out of the wood, and observed to drive back her pigs from its extremity, grunting with much earnestness, in a manner so intelligible, that they retired at her command, and waited patiently for her return. It is evident that creatures far excelling the swine in sagacity do not appear to notice a diminution in the number of their young, or take any precautions for their safety. 
It is said that the estates of $\mathrm{Mr}$. Campbell, in the West Indies, have sold for a much larger sum than was expected, and that his affairs bear a very favourable aspect. How sincerely should I rejoice, were he able to repay your fortune, and recal you from your long banishment from your affectionate friend, EMILY. 


\section{LETTER XXXIV.}

FROM CAROLINE TO EMILY.

DEAR EMILY,

The report you heard of Mr. Campbell's prosperity is true. Several things, besides the advantageous sale of his West Indian property, have contributed to make him, once more, a man of fortune; particularly the death of his eldest brother, who, being a rich bachelor, has left him a considerable sum of money. These circumstances, uniting with his own exertions and skill in business, have reinstated his affairs, and enabled him to repay me what is my due. I had a letter from him last week, in which he informs me of these particulars, and, in the kindest manner, invites me to return to his house, where he assures me I shall always find an affectionate home. This proposal I cannot accept, though I feel very grateful for that, and many former marks of paternal regard. Yet the sacrifice would be too great. The alteration in my taste and habits has unfitted me for a town life; and my attachment to 
Mrs. Saville is so great, I would not quit her for the wealth of India, especially as she will shortly be deprived of the society of her dear Rachel, who is on the point of giving her hand to Mr. Henry Palmer. The match is very agreeable to Mrs. Saville, but Rachel will live at twenty miles' distance. I shall be a poor substitute for such a daughter; yet every thing that tenderness, respect, and filial affection can inspire, I shall fulfil, as the most delightful task of my life. The sense of pecuniary obligation has long been the only allay to my enjoyment: this unexpected change of circumstances relieves me from this uneasiness, and enables me to render Mrs. Saville's situation affluent. I have no other pleasure in riches, but sharing them with these dear friends. I am under the necessity of coming to London, to take possession of my property, but shall wait till the marriage is over, when my aunt and cousins will accompany me. It will not be more that a fortnight before I shall be with you ; of course, our correspondence will cease till my return, when we must once more be contented with this kind of communication, unless you will be induced to try the retirement of a Welsh cottage, and take up your abode with us for a ferw months; a proposal that I hope you will not refuse. But I believe you will be easily persuaded to accept it, when you are acquainted with my Cambrian 
friends. I shall then enjoy as much felicity as is to be found, when surrounded by all I love best; and already anticipate the delightful rides, walks, and conversations, we shall have together. Our friends, the Palmers, will join our society, and complete our intellectual entertainment.

As instinct has so long been my theme, I shall terminate our correspondence with some remarks* on that subject, by Mr. Palmer, which are the result of observation, and have afforded me much gratification. It is matter of curious speculation, to consider how the instinct of animals grows weaker in proportion to their closer approximation towards mankind and their dwellings.

The beaver, the carcasou, and many other animals in their entire savage state, when seldom approached by human beings, seem to have the dominion of the wild, and to exercise a degree of forethought and wisdom, both in procuring what is necessary, and in avoiding what is dangerous, that appears incredible to those who, living in a cultivated country, have no means of tracing the progress of this wonderful sagacity. The cause of this faculty becoming more obtuse when animals are, to a certain degree, associated with man, when they enjoy his protection and inhabit his domains, is sufficiently ob-

* I am indebted to Mrs. Grant for these remarks. 
vious. Nature, both liberal and frugal, always does enough to obtain her purpose, but resumes her gifts when no longer useful. This applies particularly to those animals which we merely protect and fatten, without expecting from them any services that require a recollection of the past, anticipation of the future, or, in short, any exercise of those powers which do not, like instinct, operate uniformly, but are rather a kind of borrowed light from the rational powers of the thinking and governing nature. Kine, for instance, in a wild state, possess an acuteness both of sight and smell, and a spirit and fierceness in defending their young, which entirely disappear when, by domestication, we have reduced them to a condition in which the former of these qualities would be of no value, and the latter, dangerous to themselves and others. In their wild state, they distinguish by the smell the grass where the footsteps of man are to be traced, and particularly that where any person has sat or lain, with symptoms of the utmost rage and horror.

This degradation of the natural instincts is apparent in sheep, goats, fowls, \&c. In horses and dogs, too, they are much diminished; but here is a wonderful substitute provided, in that borrowed light formerly mentioned. It is not to feed upon them, but to make their strength, their diligence, their sagacity and at- 
tachment, subservient to various important purposes, that we tame and teach those generous and affectionate animals. And here I must pause, to observe the wise order of Providence in setting certain limits to the dominion of man, over the subordinate creatures. Those which, from their habits or the peculiar conformation of their bodies, are not fitted to love us, or labour in our service, as the dog and the horse, or to clothe or feed us, as kine, sheep, and poultry, resist all our efforts to domesticate them, by refusing to continue their species in that state of imprisonment and degradation to which we would subject them. All those whom their nature and instincts peculiarly fit for consuming the waste fertility of the untrodden forests, or for pursuing their prey where the hot and enervating climate might sink the inhabitants into unmanly softness, without such an enemy to stimulate their courage and prompt their vigilance; such animals refuse the yoke of subjection, and, in confinement, their instinct decays, or appears in some mode useless to themselves and pernicious to others, of which many instances might be given.

The beaver, in particular, in his native state, is superior in forethought, and something like intelligence, to every inhabitant of the wild. He is politic, vigilant, social, and, one might almost add, patriotic, when his incessant labours for the public good are 
considered. He is most industrious, and most versatile in the modes of his industry; being, by turns, a labourer, a wood-cutter, a plasterer, a house-builder, and a frugal and provident caterer: he is a sentinel too, occasionally; and, in self-defence, a soldier. No difficulties discourage, no toils exhaust him: patient and indefatigable beyond all example, he sees the labour of years, those immense trees which have been formed into barriers seemingly immovable, by the incredible strength and unwearied exertions of the whole community, - he sees these monuments of his toil swept away by the floods, and instantly begins, with renewed and undaunted activity, to repeat, for the same purpose, the same labours. Behold this powerful artificer in a state of captivity: (for that cannot be termed subjection, where there is neither obedience nor docility:) no creature can be more awkward or unsightly, or seemingly less adapted to serve or to please. Those strong, short legs, and the sideling gait, which were so well adapted for assisting his associates in dragging the trees they had previously felled, make him appear more ungainly than can be easily conceived. The trowel-tail seems to drag on the ground, as a useless incumbrance; and, from its flat, broad form, and naked surface, suggests the idea of something amphibious. Thus odd and unpleasing in its appearance, its habits are not more captivating. 
The fine instinct which exalts it in a wild state above other animals, seems degraded or perverted. The only distinction it shows its master, is forbearing to bite him, which it is very ready to do to strangers. It will follow him in the uncouth manner I have described, and, from the habit of ceaseless industry that it has acquired in a state of liberty, works, except in the depth of winter, the whole night long. When wild, it collects food in the day, and cuts and drags wood in the night. When tamed, which can only be done by taking it whilst very young, it is necessary, on account of its restlessness, to leave it out in the yard. There it employs itself the whole night in carrying fire-wood from the pile, and blocking up the door with it; so that when the family rise in the morning, they find themselves barricaded with a quantity of wood, that takes no small time to remove.

From what has been already said, it appears that the sagacity of animals is in its highest perfection, in the two extremes of utter estrangement from man, or that intimate familiarity with him which results partly from sharing his pursuits and occupations. In the former case, being entirely unaided and umprotected by human power and intelligence, more sagacity is requisite to provide for its wants, and shun or conquer its enemies. In the latter, while receiving 
kindness, and a sort of culture from his master, the reciprocation of good offices, as well as the similarity of pursuits, in which the dog and horse, for instance, are associated with the shepherd and the hunter, seems to enlighten the former with a ray of human reason, and warm them with a degree of human affections. It is in that intermediate state, when the animal has lost the wild freedom of the forest,when it is become the slave of man, without acquiring the privilege of being his friend and companion,that instinct languishes, without being replaced or improved by that borrowed beam from human intelligence, to which I have so often alluded. Man, born lord of the inferior creatures, with powers to conquer the strong and circumvent the subtle, is himself an example of this interregnum : that languid, enfeebled state of the faculties, when neither stimulated by necessity, as in a state of unrestrained freedom and independence, nor cultivated by superior intelligence, when relieved from the pressure of the former condition. The savage, when advanced to a kind of social state,-when, like the beaver or the bee, he forms part of a community,_builds a habitation, and provides for future wants. In this period of advancement, the savage, whose life of perpetual exigencies keeps all his inferior faculties in continual exercise; who knows no restraint, hopes for nothing 
but what he can easily attain, and fears no enemy but such as he is accustomed to subdue: such a savage, though his rational powers cannot be said to be unfolded,- - though he has not attained to the privileges, or assumed the dignity, of which reasoning man is capable,-is still a noble animal, in comparison with the enslaved and unenlightened peasants, who groan, in many parts of the world, under the iron hand of oppression; without being visited by the light that leads to heaven, or exalted by the arts that promote our ease and comfort in the present life. The savage is more quick of apprehension, more swift of foot, more acute in all his senses, more dexterous, more ingenious; in short, much better qualified to supply his own wants, procure his own enjoyments, and resist physical evils of every kind.

Nor, in the blended proportion of physical and intellectual powers, does man, in this enslaved and uninstructed state, bear the same rank among his fellow-men, as animals domesticated, yet not caressed or cultivated, do among their fellow-animals. I know only one instance in which an example may be found of the wild instinct being little impaired, and a kind of borrowed intelligence superadded. This is the Highland cattle, whose wide, free range in the mountains, is calculated to cherish their native instinct; and were it not for early domestic education, 
would be apt to restore them to their primitive habits. But the severity of the winter, and the scarcity of provender, oblige the poor people to nurse the breeders, and even the last year's calves, with great tenderness. In this case, affection becomes grafted on interest. A poor man, who has at most only three milch-cows and a couple of stirks, as they call the last year's calves, that they may be kept warm and well tended, keeps them under his own roof. They are placed in the further end of the house, divided from the rest by a very slight screen of sticks and clay, and often in a situation where they always are within view of their owners. A few sheep and a little horse excepted, these creatures are all their worldly wealth, and therefore the chief objects of their solicitude. Not content with almost starving themselves to purchase food for them in years of scarcity, they caress and talk to them, in a voice so soothing, and language so endearing, and the animals seem so conscious and so grateful, and bẹcome so very much a part of the family, that it is affecting to see the mutual kindness that subsists between them. Yet it is surprising that animals so wild and lively in all their motions, should be susceptible of such lasting impressions, and retain so perfect a recollection of all their friends, after six months' absence in the mountains. When thus kindly spoken to, strok- 
ed, and caressed, they express their complacence by a peculiar kind of breathing, that gives the idea of placid content. Nor is this the only expression of their sensibility. On meeting their old acquaintance after a long absence, they greet them with plaintive lowings. They acquire a taste for music, too, whilst dwelling in these vocal cottages, where the roice of song is so frequently heard. This rural melody certainly calms the irritation produced by heat and insects in a summer's evening, when, without it, they could not be milked with safety. This is a fact so well established, that a girl is not thought fit for a dairy-maid unless she can sing; and if it so happens, in some rare instance, that one who has no power of voice is selected for this employment, she takes another with her who can sing, to assist in milking, and to lull the fold with the wonted strains that are peculiar to this avocation; the theme of which is generally either the habits of cattle, their favourite summer haunts, or the simple adventures of those who attend them. Thus fondled, and made at one period, as it were, a part of society, and at another let loose to the boundless range of the summer pastures, they are in some degree cultivated, and retain much of the instinctive faculty, without any of the ferocity, of the wild animal of the same 
species. They will recognise, after a long absence, and fondly caress, their own calves, after they have become mothers of another race; and even caress the young of those, from fondness for the parent who has been so long estranged from them. Many instances of the sagacity of these creatures are well authenticated by those who reside in the country, which, by the inhabitants of other parts, would be deemed incredible. One, however, I shall mention, as having fallen under the inspection of a particular friend,* on whose veracity I can rely.

The whole country near Laggan, where my friend lived, was uninclosed. When he took possession of his farm, there was hardly a march dyke, as division fences are called there. A mere slight, ideal boundary, or, at most, marked by a range of stones, separated his fields from those of his neighbours. This gentleman had a lead-coloured bull, who was a beautiful creature of his kind, and grazed with the cows in the open meadows. It was the constant occupation of a boy, kept for the purpose, to watch the milch-cows and their guardian, lest they should trespass on his neighbour's fields, and destroy his corn. This boy was fat and drowsy, and was

* Mrs. Grant, when resident at Laggan. 
often found asleep on his post; an offence as umpardonable in a Highland herd as in a sentinel. The ploughman, provoked at the frequency of this fault, chastised the boy whenever the cattle trespassed. The boy, enraged at this, kept a long switch, and with it revenged himself with an unsparing hand, if they exceeded their boundary. The bull seemed to have observed with concern this consequence of their transgression, and acted upon his observation. He had no horns, as is frequently the case with northern cattle; but then he had a hard and powerful forehead, with which he used to strike the cows, and punish them severely if any one attempted to cross the limit, or in any way trespass. In the mean time, he set them the example of perfect self-denial, never onc entering the forbidden bounds, and placing himself before the cows in a threatening attitude if they presumed to approach it. At length his honesty and vigilance became so obvious, that the boy was employed in weeding and other business, without fear of their misbehaviour in his absence. This fine animal's vigilance could only proceed from a desire to keep his companions from punishment, not from any distinction of property.

With this extraordinary account I close my letter and my correspondence; at the same time, 
fully impressed with the expectation of very shortly enjoying the pleasure of your conversation, which will be better than a hundred letters.

Till we meet, and ever afterwards, your sincere and affectionate friend,

Caroline.

THE END. 
LONDON :

PRINTED by SAMUEL BENTLEy, Dorset Street, Fleet Street. 


SMITHSONIAN INSTITUTION LIBRARIES

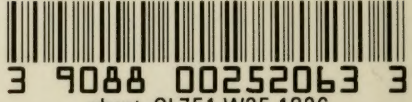
nhent QL751.W25 1836

Instinct displayed in a collection of we
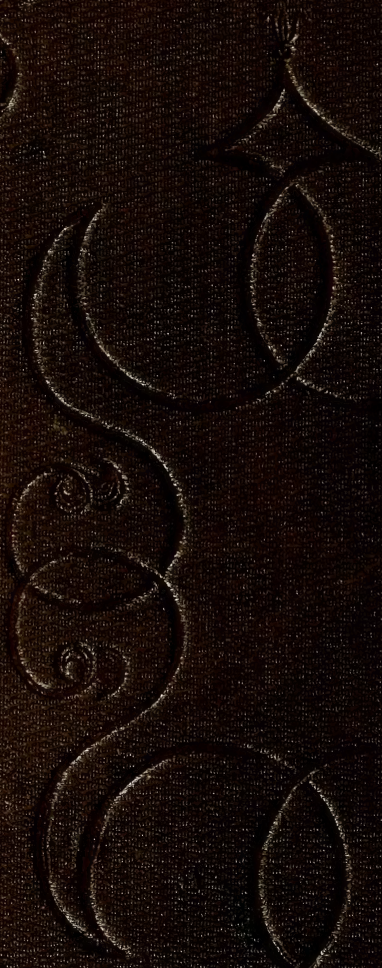